\title{
Nathalia Molina
}

\section{"Avaliação de parâmetros oxidativos e funcionais em linfócitos de ratos obesos suplementados cronicamente com extrato de chá verde"}

Dissertação apresentada ao Programa de Pós-Graduação em Farmacologia do Instituto de Ciências Biomédicas da Universidade de São Paulo, para obtenção do Título de Mestre em Farmacologia.

São Paulo

2014 


\section{Nathalia Molina}

\section{"Avaliação de parâmetros oxidativos e funcionais em linfócitos de ratos obesos suplementados cronicamente com extrato de chá verde"}

Dissertação apresentada ao Programa de Pós-Graduação em Farmacologia do Instituto de Ciências Biomédicas da Universidade de São Paulo, para obtenção do Título de Mestre em Farmacologia.

Área de concentração: Farmacologia

Orientadora: Profa. Dra. Rosemari Otton

Versão Original 
DADOS DE CATALOGAÇÃO NA PUBLICAÇÃO (CIP)

Serviço de Biblioteca e Informação Biomédica do

Instituto de Ciências Biomédicas da Universidade de São Paulo

(c) reprodução total

Molina, Nathalia.

Avaliação de parâmetros oxidativos e funcionais em linfócitos de ratos obesos suplementados cronicamente com extrato de chá verde / Nathalia Molina. -- São Paulo, 2014.

Orientador: Profa. Dra. Rosemari Otton.

Dissertação (Mestrado) - Universidade de São Paulo. Instituto de Ciências Biomédicas. Departamento de Farmacologia. Área de concentração: Farmacologia. Linha de pesquisa: Obesidade, sistema imunológico, compostos bioativos.

Versão do título para o inglês: Evaluation of oxidative and functional parameters in lymphocytes of obese rats chronically supplemented with green tea extract.

1. Chá verde 2. Catequinas 3. Obesidade 4. Dieta hipercalórica

5. Sistema imune 6. Linfócitos I. Otton, Profa. Dra. Rosemari

II. Universidade de São Paulo. Instituto de Ciências Biomédicas.

Programa de Pós-Graduação em Farmacologia III. Título. 
Candidato(a):

Título da Dissertação:

Orientador(a):
Nathalia Molina.

Avaliação de parâmetros oxidativos e funcionais em linfócitos de ratos obesos suplementados cronicamente com extrato de chá verde.

\author{
Profa. Dra. Rosemari Otton.
}

A Comissão Julgadora dos trabalhos de Defesa da Dissertação de Mestrado, em sessão pública realizada a .$/ \ldots$ , considerou
( ) Aprovado(a)
( ) Reprovado(a)
Examinador(a): Assinatura: Nome:
Instituição:
Examinador(a): Assinatura:
Nome:
Instituição:
Presidente: Assinatura:
Nome:
Instituição:




\section{Certificado}

Certificamos que o protocolo registrado sob $n^{\circ} \mathbf{1 6 0}$ nas fls. $\mathbf{1 3 7}$ do livro 02 para uso de animais em experimentação, sob a responsabilidade do Prof(a) Dr(a)) Rosemari Otton, Coordenador (a) da Linha de pesquisa "Avaliação sistemática de parâmetros oxidativos e inflamatórios em leucócitos de ratos obesos suplementados cronicamente com extrato de chá verde (Camellia sinensis)" do qual participam o(s) aluno(s), Anaysa Paola Bolin, Karen Fernanda Felix de Albuquerque, Nathalia Molina, está de acordo com os Princípios Éticos de Experimentação Animal adotado pela Sociedade Brasileira de Ciência de Animais de Laboratório (SBCAL) e foi aprovado pela COMISSÃO DE ÉTICA NO USO DE ANIMAIS (CEUA) em 28.05.13, com validade de 4 anos.

São Paulo, 29 de maio de 2013.
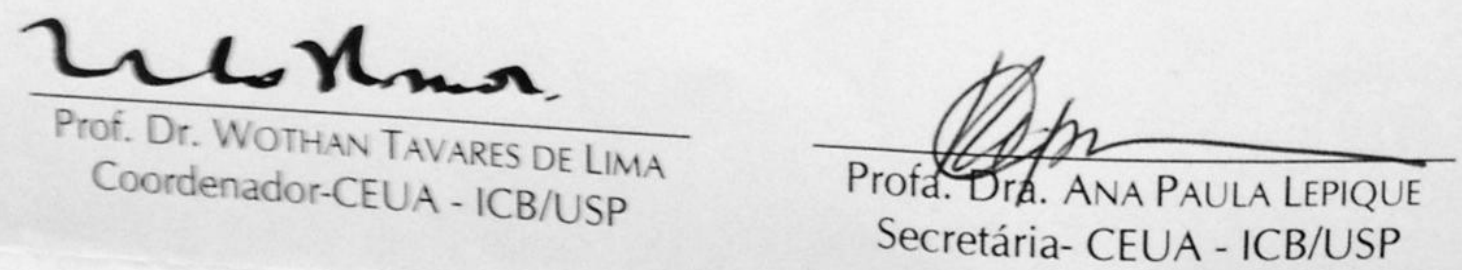
"À minha família e ao meu noivo, profundos incentivadores de toda minha trajetória profissional". 


\section{AGRADECIMENTOS}

"Cada pessoa que passa em nossa vida, passa sozinha. Porque cada pessoa é única e nenhuma substitui a outra! Cada pessoa que passa em nossa vida passa sozinha e não nos deixa só porque deixa um pouco de si e leva um pouquinho de nós. Essa é a mais bela responsabilidade da vida e a prova de que as pessoas não se encontram por acaso."

Charles Chaplin

Durante esses dois anos só tenho a agradecer a todos que passaram pelo meu caminho e que com certeza deixaram um pouco de si. Os momentos de alegria serviram para me permitir acreditar na beleza da vida, e os de sofrimento, serviram para um crescimento pessoal único. É muito difícil transformar sentimentos em palavras, mas serei eternamente grata a vocês, pessoas imprescindíveis para a realização e conclusão deste trabalho.

Primeiramente agradeço a Deus, pela vida e força.

Aos meus pais, irmãs e ao meu noivo, pela força, paciência e incentivo que me deram durante todo esse período, principalmente acreditando que no final tudo daria certo.

À minha orientadora Profa. Dra. Rosemari Otton, pela orientação. Só tenho a agradecer aos seus ensinamentos (pessoais e acadêmicos), orientações, palavras de incentivo, puxões de orelha, paciência e dedicação. Você é uma pessoa ímpar, onde busco inspirações para me tornar melhor em tudo que faço e irei fazer daqui para frente.

Aos Profs. Dr. Marcelo Nicolás Muscará, Dra. Carolina Demarchi Munhoz e Dra. Renata Gorjão, pelas contribuições realizadas a esse trabalho durante o exame de qualificação.

Aos animais, parte fundamental desse trabalho, obrigada por suas contribuições a ciência.

À CAPES e á FAPESP, pelo auxílio e apoio concedido, que foi de fundamental importância para o desenvolvimento desse trabalho.

Aos amigos do laboratório de Fisiologia Celular e Biologia Molecular:

Anaysa Paola Bolin, Andrea Rocha, Karen Felix, Marcelo Marinovic e Rita de Cássia, amigos e companheiros sempre dispostos a ajudar, vocês foram fundamentais nesses dois anos de trabalho, desde os pequenos até os grandes problemas. Obrigada pelos incentivos na parte experimental seja durante o dia ou noite, com chuva, neblina ou sol. Por acreditarem que tudo daria certo no final, mesmo quando a esperança era quase nula. Pelos ouvidos que escutaram tantas reclamações e pelas risadas que amenizavam o stress diário. 
"De tudo ficaram três coisas: a certeza de que estamos sempre começando... a certeza de que é preciso continuar... a certeza de que seremos interrompidos antes de terminar...

Portanto devemos:

fazer da interrupção um caminho novo... da queda, um passo de dança... do medo, uma escada... do sonho, uma ponte... da procura... um encontro..." (Fernando Sabino em "o encontro marcado") 


\section{RESUMO}

MOLINA, N. Avaliação de parâmetros oxidativos e funcionais em linfócitos de ratos obesos suplementados cronicamente com extrato de chá verde. 2014. 99 f. Dissertação (Mestrato em Farmacologia) - Instituto de Ciências Biomédicas, Universidade de São Paulo, São Paulo, 2014.

O excesso de adiposidade pode causar um impacto negativo na função imunológica e na defesa do organismo contribuindo assim para a maior suscetibilidade de indivíduos obesos à infecções e outras patologias. O chá verde apresenta ações anti-inflamatórias, antioxidante, antiproliferativa, antiobesidade, entre outras. O objetivo deste trabalho foi investigar se 0 extrato de chá verde (CV) seria capaz de modular alguns parâmetros funcionais de linfócitos de animais induzidos à obesidade por dieta hipercalórica (DH). Para isso, ratos Wistar machos foram divididos em 4 grupos: controle (DP - dieta padrão), chá verde (DP com CV), obeso (DH sem CV) e obeso+chá (DH com CV). Os grupos DP com CV e DH com CV receberam $500 \mathrm{mg} / \mathrm{kg}$ do extrato de chá verde durante 22 dias e então se deu início a dieta hipercalórica por 8 semanas acompanhada também do tratamento com o extrato do chá verde. Após 66 dias de suplementação, os linfócitos dos animais foram obtidos a partir dos linfonodos mesentéricos para a realização dos ensaios: avaliação da capacidade proliferativa dos linfócitos estimulados com ConA e LPS durante $48 \mathrm{~h}$, atividade da enzima glicose-6-fosfato-desidrogenase (G6PDH), hexoquinase, liberação intracelular de cálcio, produção de espécies reativas de oxigênio (ERO), atividade das enzimas antioxidantes superóxido dismutase (SOD), catalase (CAT), glutationa peroxidase (GPx), glutationa redutase (GR), razão das glutationas GSH/GSSG e a liberação de citocinas pró- e antiinflamatórias (IL-2, IL-6, IL-1 $\beta$, TNF- $\alpha$, IFN- $\gamma$ e IL-10). Como resposta à dieta hipercalórica, foi observado no grupo $\mathrm{DH}$ sem $\mathrm{CV}$ um aumento na atividade da enzima metabólica hexoquinase. Estes também apresentaram uma maior produção de ERO e consequentemente aumento na atividade das enzimas SOD Mn, CuZn e GR. Foi observado um aumento na proliferação dessas células na condição basal. Em relação à produção de citocinas, observamos uma redução na produção de IL-10, que é uma citocina antiinflamatória. Já o grupo $\mathrm{DH}$ com $\mathrm{CV}$, apresentou redução na proliferação celular sob o estímulo de ConA, redução na atividade das enzimas metabólicas hexoquinase e G6PDH, aumento na atividade das enzimas SOD CuZn e Mn, GPx e GR, porém a produção de ERO se mostrou diminuída. Em relação às citocinas, esse grupo apresentou diminuição na liberação de IL-2, IL-6, IL-1 $1 \beta$, TNF- $\alpha$ e restauração dos índices de IL-10 que se encontrava diminuída no grupo obeso. O grupo chá que recebeu dieta padrão (DP com CV) apresentou resultados similares ao grupo $\mathrm{DH}$ com $\mathrm{CV}$ sugerindo com isso que muitos dos efeitos observados na suplementação do chá verde foram devido à ação desse fitoterápico independente da presença da obesidade. Assim este estudo demonstrou que o modelo de indução à obesidade por dieta hipercalórica foi capaz de modular as funções dos linfócitos, principalmente na produção de ERO e diminuição da produção de IL-10, que poderia estar contribuindo para o estado inflamatório presente na obesidade. Já o tratamento crônico com chá verde foi capaz de melhorar o estado redox e diminuir a liberação de citocinas inflamatórias pelos linfócitos, proporcionando assim um ambiente mais adequado para 0 bom funcionamento celular com diminuição do quadro inflamatório presente na obesidade.

Palavras-chave: Chá verde. Catequinas. Obesidade. Dieta hipercalórica. Sistema imunológico. Linfócitos. 


\begin{abstract}
MOLINA, N. Evaluation of oxidative and functional parameters in lymphocytes of obese rats chronically supplemented with green tea extract. 2014. 99 p. Masters thesis (Pharmacology)- Instituto de Ciências Biomédicas. Universidade de São Paulo, São Paulo, 2014.

The excess body fat has a negative impact on immune function and in the body's defense, therefore contributes to increased susceptibility of obese individuals to infections and other diseases. Green tea has anti-inflammatory, antioxidant, antiproliferative, anti-obesity, among other actions. The objective of this study was to investigate whether green tea extract (CV) would be able to modulate some functional parameters of lymphocytes from obese animals induced by cafeteria hipercaloric diet (DH). For this, male Wistar rats were divided into 4 groups: control (DP - standard diet), green tea (DP with CV), obese (DH without CV) and obese + tea (DH with CV ). The groups DP with CV and DH with CV received $500 \mathrm{mg} / \mathrm{kg}$ of green tea extract for 22 days and then started the $\mathrm{DH}$ for over 8 weeks also accompanied by the treatment with green tea extract. After 66 days of supplementation, the lymphocytes were obtained from mesenteric lymph nodes for the tests: assessment of the proliferative capacity of lymphocytes stimulated with Con A and LPS, the activity of the enzyme glucose -6phosphate dehydrogenase (G6PDH), hexokinase, intracellular calcium release, production of reactive oxygen species (ROS), activity of antioxidant enzymes superoxide dismutase (SOD), catalase (CAT), glutathione peroxidase (GPx), glutathione reductase (GR), glutathione ratio (GSH/GSSG) and the release of pro - and anti - inflammatory (IL- 2, IL- 6, IL- $1 \beta$, TNF- $\alpha$, IFN- $\gamma$ and IL -10). In response to diet it was observed in the group DH without $\mathrm{CV}$ an increase in the metabolic enzyme hexokinase activity. They also showed a higher ROS production and consequently increase in the activity of Mn SOD, CuZn and GR enzymes. An increase in the proliferation of these cells at baseline was observed. For the production of cytokines, a decrease in production of IL-10, which is an anti -inflammatory cytokine. The group DH with CV decreased cell proliferation under ConA stimulation, the activity of metabolic enzymes hexokinase and G6PDH, increased the activity of CuZn SOD and Mn SOD, GPx and GR enzymes, whereas ROS production was decreased. Regarding cytokines, this group showed a decrease in the release of IL - 2 , IL - 6 , IL-1 $1 \beta$, TNF - $\alpha$ levels and restoration of IL- 10 that was impaired in the obese group. The tea group that received standard diet (DP with CV) showed similar results the DH with CV group thereby suggesting that many of the effects observed in the supplementation of green tea have been due to the action of this herbal and not due to the presence of obesity. Thus the induction model to obesity by calorie diet was capable of modulating lymphocyte functions, mainly in the production of ROS and decreased production of IL-10, which could be contributing to this inflammatory state in obesity. The chronic treatment with green tea was able to improve the redox state and decrease the release of inflammatory cytokines by lymphocytes, thus providing a more adequate environment for proper cell function with decreased inflammation present in obesity.
\end{abstract}

Keywords: Green tea. Catechins. Obesity. Hypercaloric Diet. Immune system. Lymphocytes. 


\section{LISTA DE ILUSTRAÇÕES}

Figura 1 - Diferenciação de linfócitos T

Figura 2 - Influência do metabolismo energético na diferenciação dos subtipos de linfócitos $T$ 23

Figura 3 - Integração dos sistemas de defesa enzimáticos e relação com enzimas metabólicas 27

Figura 4 - Composição celular do tecido adiposo de indivíduos saudáveis e de indivíduos obesos 34

Figura 5 - Ilustração da planta Camellia sinensis .37

Figura 6 - Estrutura básica dos flavonoides 38

Figura 7 - Ilustração das catequinas do chá verde .38

Figura 8 - Teste de tolerância à insulina $(A)$ .59

constante de decaimento da glicose (B) .59

e teste de tolerância à glicose $(\mathrm{C})$ 60

Figura 9 - Concentração plasmática de leptina 62

Figura10 - Concentração plasmática de adiponectina .63

Figura 11 - Concentração plasmática de ácidos graxos 64

Figura 12 - Capacidade proliferativa dos linfócitos 67

Figura 13 - Avaliação da mobilização intracelular de cálcio em linfócitos .70

Figura 14 - Avaliação da produção de espécies reativas de oxigênio pelas sondas DHE (A) .72

DCFH-DA (B) .73

Figura 15 - Modelo de atuação do chá verde sobre os linfócitos .86 


\section{LISTA DE TABELAS}

Tabela 1 - Composição nutricional referente à $100 \mathrm{~g}$ da dieta de cafeteria

Tabela 2 - Caracterização da obesidade pela avaliação do ganho de peso (peso final menos peso inicial dos animais). IA- índice de adiposidade (soma dos pesos dos depósitos de gorduras epididimal, subcutâneo, perirenal e tecido adiposo marrom / $100 \mathrm{~g}$ de peso corporal), e avaliação individual dos pesos dos depósitos de gorduras/ $100 \mathrm{~g}$ de peso corporal dos animais .61

Tabela 3 - Produção de citocinas por linfócitos 69

Tabela 4 - Valores referentes à avaliação da atividade das enzimas antioxidantes SOD ( $\mathrm{Mn}$ e $\mathrm{Cu} / \mathrm{Zn}$ ), CAT, GPx e GR, avaliação da razão GSH/GSSH e atividade das enzimas metabólicas G6PDH e

hexoquinase. 
AGL

APCs

$\mathrm{Bcl}-2$

BCR

CAT

CD

Células NK

Células Th

ConA

CV

DAMPs

DCNT

DH

DP

EC

ECG

EGC

EGCG

EROs

G6PDH

GPx

GR

GSH

GSSG

GTT

IMC

iNOS

IRS

ITT

IL-1 $\beta$

IL-6
Ácidos graxos livres

Células apresentadoras de antígenos

Proteína anti-apoptótica

Receptor de células B

Catalase

Grupo de diferenciação

Células Natural Killer

Células T helper

Concanavalina A

Chá verde

Moléculas padrão associadas a danos

Doenças crônicas não transmissíveis

Dieta hipercalórica

Dieta padrão

Epicatequina

Epicatequina galato

Epigalocatequina

Epigalocatequina 3-galato

Espécies reativas de oxigênio

Glicose 6-fosfato desidrogenase

Glutationa Peroxidase

Glutationa Redutase

Glutationa Reduzida

Glutationa Oxidada

Teste de tolerância à glicose

Índice de massa corporal

Óxido nítrico sintase induzível

Substrato do receptor de insulina

Teste de tolerância à insulina

Interleucina 1 beta

Interleucina 6 
IL-10

INF-Y

Kitt

LPS

MCP-1

MHC

MyD88

mTOR

NFAT

NO

$\mathrm{NO}^{+}$

NO

$\mathrm{O}_{2} \cdot$

$\mathrm{OH}$

OONO-

OMS

PMA

PKC

PI3K

$\mathrm{PIP}_{2}$

$\mathrm{PIP}_{3}$

PTP

PTK

SOD

TLR

TGF- $\beta$

Treg
Interleucina 10

Interferon gamma

Constante de decaimento da glicose Lipopolissacarídeo

Proteína quimiotática de monócitos

Complexo principal de

histocompatibilidade

Fator de diferenciação mieloide 88

Alvo de rapamicina em mamíferos

Fator nuclear de célula $T$ ativadas

Óxido nítico

Cátion nitroso

Ânion nitroxila

Ânion superóxido

Radical hidroxila

Peroxinitrito

Organização Mundial de Saúde

Forbol miristato acetato

Proteína quinase $\mathrm{C}$

Fosfatidilinositol-3-quinase

Fosfatidilinositol-4,5-bifosfato

Fosfatidilinositol-3,4,5-trifosfato

Proteína tirosina fosfato

Proteína tirosina quinase

Superóxido dismutase

Receptor toll like

Fator de crescimento de diferenciação beta

Células $T$ reguladoras 


\section{SUMÁRIO}

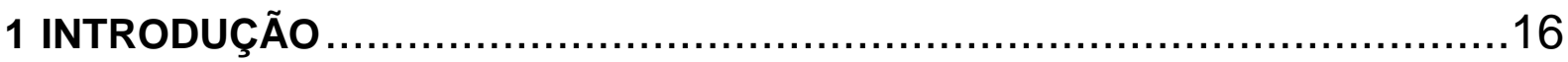

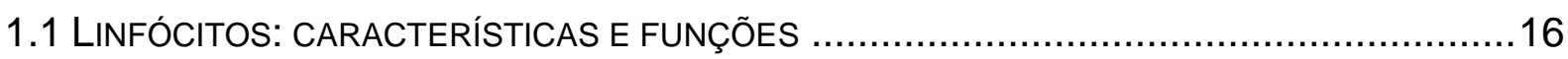

1.2 CONCEITO, EPIDEMIOLOGIA E CARACTERIZAÇÃO DA OBESIDADE …........................27

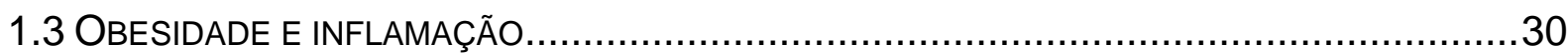

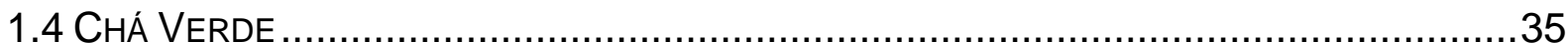

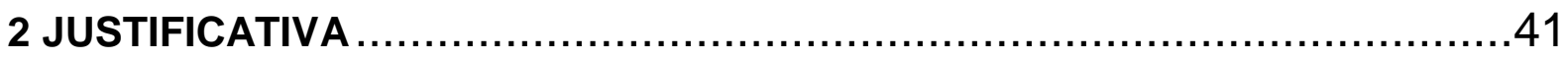

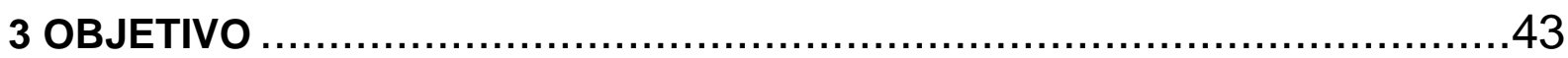

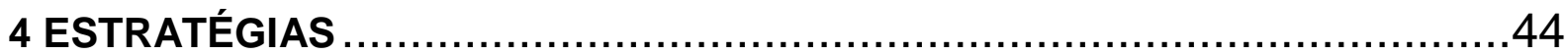

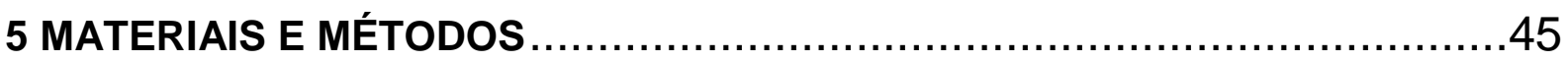

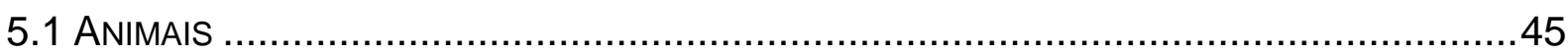

5.1.1 Grupos experimentais e tratamento com extrato de chá verde in vivo..............45

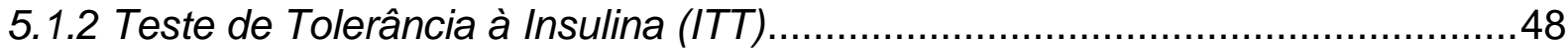

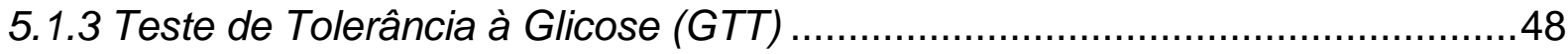

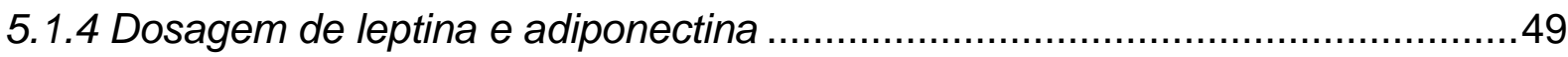

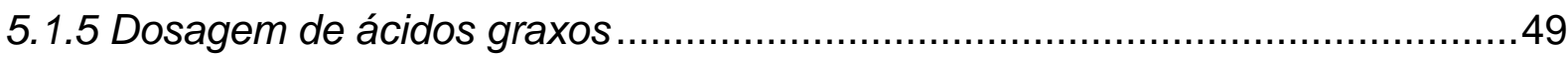

5.1.6 Avaliação das reservas de gordura epididimal, perirenal e subcutânea............50

5.2 OBTENÇÃO DE LINFÓCITOS DOS LINFONODOS MESENTÉRICOS ..................................50

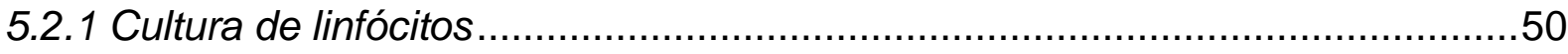

5.2.2 Determinação da capacidade proliferativa de linfócitos ...................................50

5.2.3 Ensaio de interleucinas pró- e anti-inflamatórias pelo método de ELISA ..........51

5.2.4 Avaliação da concentração intracelular de cálcio...........................................52

5.3 ProduçÃo de EROS AVALIAdO PELO ENSAIO DE DCFH-DA ................................53

5.3.1 Produção de EROs usando a sonda dihidroetidina (DHE) ..............................53

5.4 PROCEDIMENTO PARA A AVALIAÇÃO DA ATIVIDADE DAS ENZIMAS ANTIOXIDANTES E

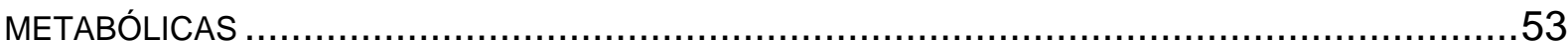

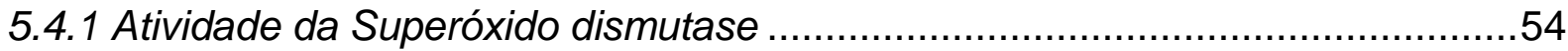

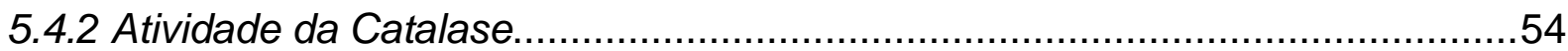

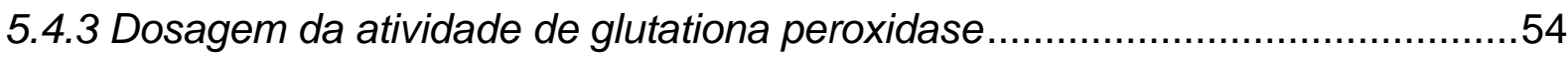

5.4.4 Dosagem da atividade de glutationa redutase ............................................55

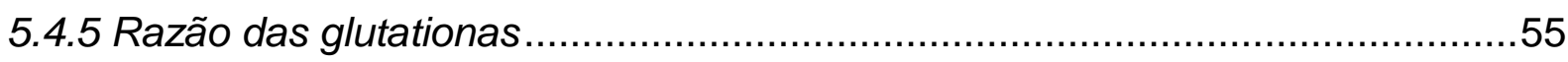

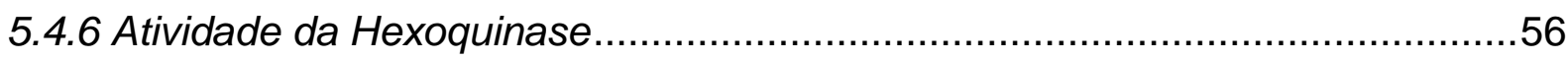

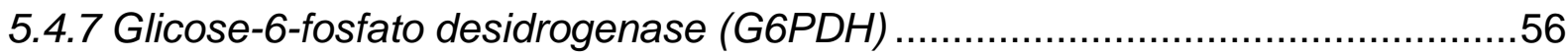


5.5 DETERMINAÇÃO DAS PROTEÍNAS TOTAIS NOS HOMOGENATOS ...............................57

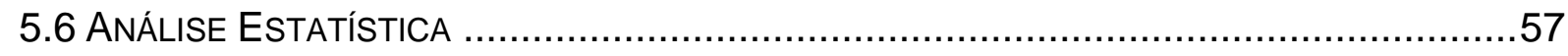

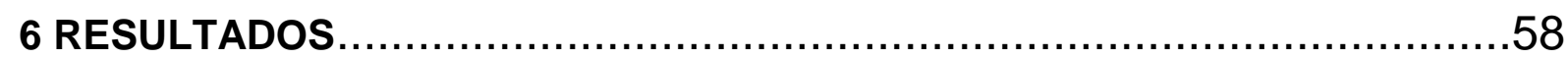

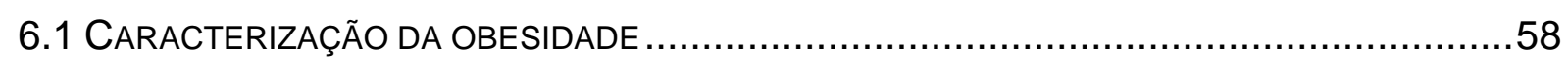

6.2 AVALIAÇÕES DE PARÂMETROS FUNCIONAIS DE LINFÓCITOS ...................................65

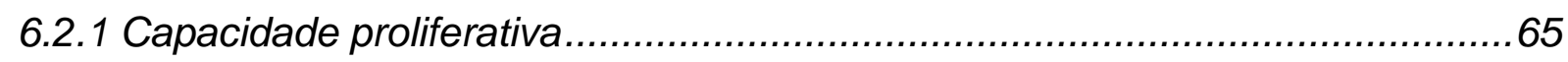

6.2.2 Produção de citocinas pró- e anti-inflamatórias............................................67

6.2.3 Liberação intracelular de cálcio ...........................................................69

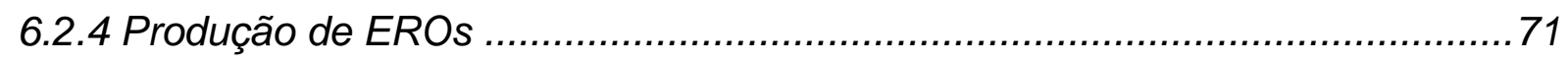

6.2.5 Atividade das enzimas SOD, Cat, GPx e GR ......................................... 73

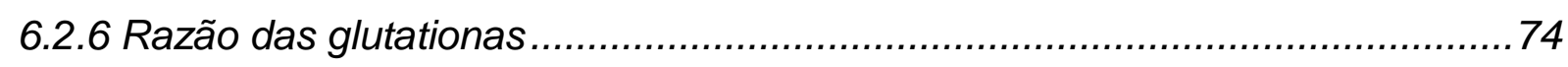

6.2.7 Atividade das enzimas metabólicas Hexoquinase e G6PDH ......................... 75

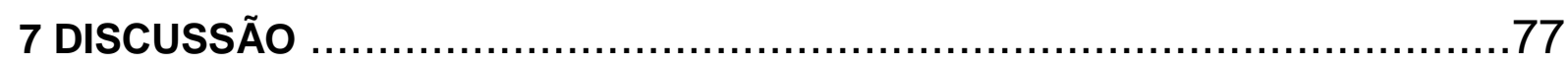

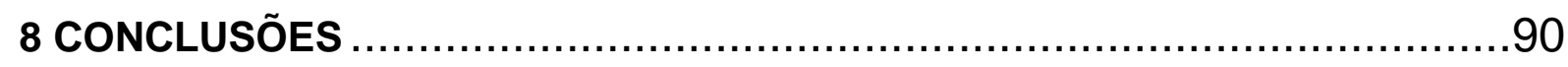

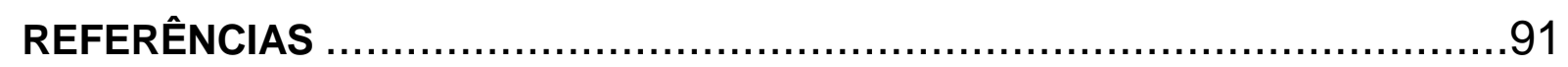




\section{INTRODUÇÃO}

1.1 Linfócitos: características e funções

O sistema imunológico é constituído por uma variedade de células e moléculas que tem por finalidade manter a homeostase do organismo, combatendo qualquer tipo de agressão. A proteção do organismo é conseguida por meio de duas respostas que podem ser classificadas como imunidade inata e adquirida, que atuam de maneira cooperativa. A inata (natural) possui o mesmo mecanismo de defesa contra a maioria dos agentes infecciosos, por isto é considerada um sistema de baixa especificidade. Epitélios, proteínas sanguíneas, fagócitos, como os neutrófilos e os macrófagos, participam deste mecanismo de defesa. A imunidade adquirida ou específica, responde de maneira particular aos vários tipos de antígenos, sendo, portanto, especializada. Este sistema é eficiente principalmente por sua memória, que the confere respostas mais vigorosas aos mesmos agentes patogênicos. Os linfócitos e os anticorpos por eles produzidos são responsáveis pela ativação deste mecanismo de defesa (MEDZHITOV; JANEWAY, 2000).

Todas as células imunes provêm da medula óssea através da hematopoiese, onde células progenitoras estão comprometidas com todas as linhagens sanguíneas. Na medula óssea as células hematopoiéticas primordiais são capazes de originar dois grandes progenitores, o mielóide e o linfóide, os quais geram todas as células do sistema imune. O progenitor mielóide dá origem aos eritrócitos, plaquetas, granulócitos (neutrófilos, eosinófilos e basófilos), mastócitos e os monócitos. O progenitor linfóide dá origem a todos os tipos de linfócitos (BÖIERS et al., 2013; SAMARTíN; CHANDRA, 2001).

Os linfócitos são leucócitos que participam tanto da resposta imune inata como da resposta imune adaptativa. Representam $20-30 \%$ de todos os leucócitos do sangue e são consideradas importantes células para as respostas imune e inflamatória. Originam-se de duas linhagens diferentes: linhagem de linfócitos $T$ e linhagem de linfócitos B. Os linfócitos T saem da medula óssea, ainda não maduros, e migram para o timo e órgãos linfoides secundários (baço, linfonodos e placas de Peyer) para então completarem sua maturação. Ao contrário destes, os linfócitos $B$ permanecem na própria medula até completarem sua maturação (BÖIERS et al., 2013). 
Os linfócitos incluem as células $T$, células $B$ e células Natural killer (NK) (KONDO et al., 2003). Células T e $B$ através de seus receptores TCR (receptor para células $\mathrm{T}$ ) e BCR (receptor para células $\mathrm{B}$ ), respectivamente reconhecem antígenos específicos e iniciam a resposta imune adaptativa. Ao contrário destas, as células NK participam da resposta imune inata, porém estudos recentes sugerem que estas células também são importantes para a resposta imune adaptativa (LEE; LEE, 2013).

As células $T$ são bastante heterogêneas e são basicamente classificadas pelos marcadores que expressam em sua superfície e funções que desempenham. A primeira classificação de células $T$ baseia-se no subtipo de receptor TCR que apresentam na superfície celular. A maioria das células $T$ apresentam o subtipo $\alpha \beta$ TCR e uma porcentagem pequena dessas células apresentam o subtipo $ү \delta$ TCR (tipicamente $<2 \%$ de toda população de células $T$ ). Estas últimas estão expressas em alto número na mucosa intestinal e no compartimento epidermal da pele e não requerem moléculas do complexo principal de histocompatibilidade ( $\mathrm{MHC}$ ) em sua superfície para realizarem suas funções (LEE; LEE, 2013).

As células $\alpha \beta$ TCR são agrupadas com base em seus marcadores de superfície em CD4 e CD8, assim como por suas funções (células T helper, células T citotóxicas, células $T$ reguladoras). Muitas células $T$ helper são células CD4 que interagem com antígenos apresentados pelas moléculas MHC II presentes em células apresentadoras de antígenos (APCs). As células $T$ helper podem ser divididas em células Th1, Th2, Th17 e células T reguladoras (Treg) na dependência do ambiente de citocinas presentes durante o estímulo fornecido por uma APC (Figura 1) (OESTREICH; WEINMANN, 2012). 
Figura 1 - Diferenciação de linfócitos T

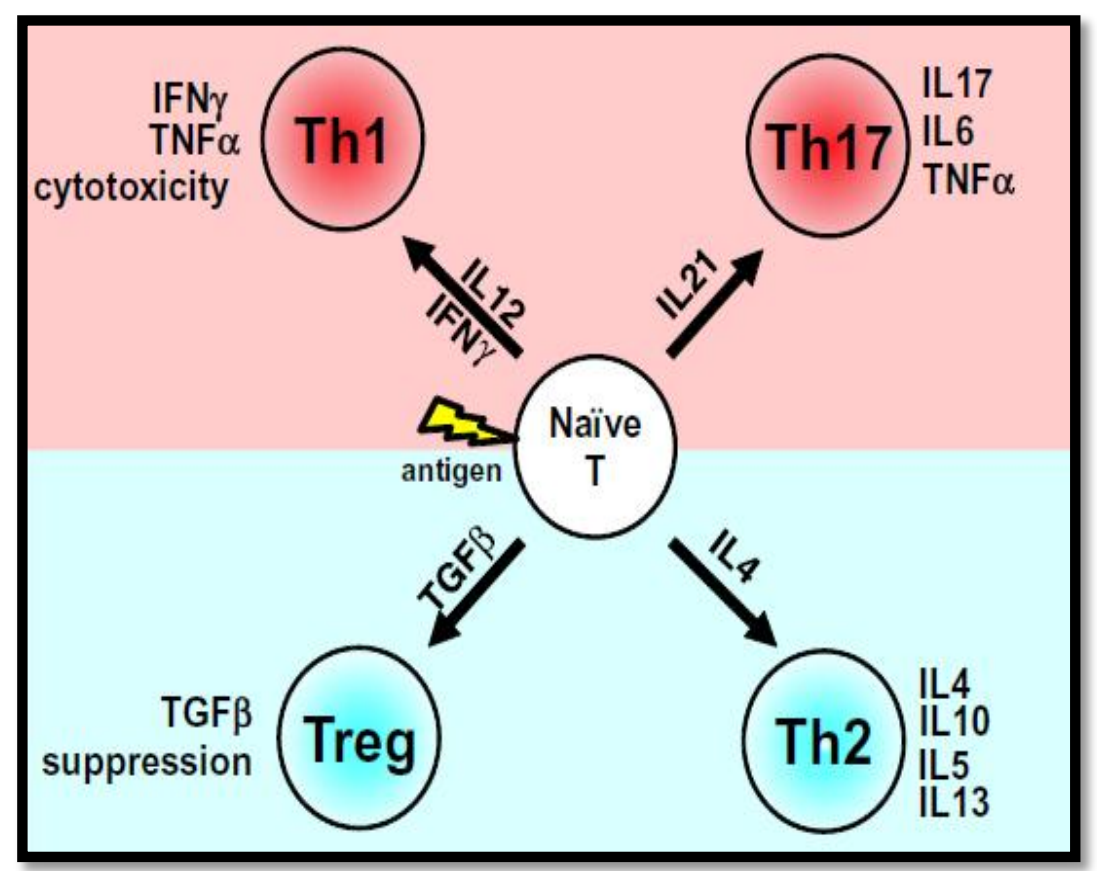

Diferenciação de linfócitos T. Quando uma célula T naïve reconhece um antígeno apresentado por uma APC, ocorre ativação e diferenciação em linhagens celulares distintas, com o perfil funcional de células $\mathrm{T}$ de memória largamente influenciados pelas citocinas liberadas no microambiente. Por exemplo, IL-12 e INF-y direcionam as células T para a linhagem de células Th1. As funções efetoras da linhagem "tipo 1" (Th1 e IL-17) podem causar dano ao hospedeiro (hiperinflamação e lise de células) enquanto que as linhagens "tipo 2" (Th2 e Treg) ajudam na supressão da resposta imune pela liberação de IL-10 e TGF- $\beta$. Fonte: Snyder-Cappione e Nikolajczyk, 2013.

Na presença dos estímulos de IL-12 e INF- $\gamma$, as células T naïve podem se diferenciar em células Th1. Os linfócitos Th1 produzem grandes quantidades de IL-2, capaz de induzir proliferação de linfócitos T (incluindo os próprios linfócitos T CD4 de maneira autócrina) e também induzir a proliferação e aumento da capacidade citotóxica dos linfócitos T CD8. A outra citocina produzida em grandes quantidades pelos Th1 é o INF- $\gamma$, uma citocina muito importante na ativação de macrófagos infectados por patógenos intracelulares, como micobactérias, protozoários e fungos, apresentando também um papel relevante na ativação de células T CD8. Existe um ciclo de retroalimentação positiva na ação do INF-y sobre outros linfócitos Th0, induzindo sua polarização para a via de diferenciação Th1 e inibindo a via Th2. A resposta Th1 é essencial para o controle de patógenos intracelulares (SNYDERCAPPIONE; NIKOLAJCZYK, 2013). 
A segunda população de linfócitos $\mathrm{T}$ helper muito importante na resposta imune humoral é o linfócito Th2, que produz IL-4, IL-5, IL-6, IL-13 e IL-10, favorecendo a produção de anticorpos. As respostas Th2 estão associadas com as doenças alérgicas e infecções por helmintos, uma vez que a IL-4 induz a troca de classe de imunoglobulinas nos linfócitos B para $\operatorname{lgE}$ e a IL-5 induz a produção e ativação de eosinófilos. De forma análoga ao INF- $\mathrm{Y}$, a IL-4 também promove retroalimentação positiva para a diferenciação Th2 e suprime a diferenciação dos linfócitos Th1 (SNYDER-CAPPIONE; NIKOLAJCZYK, 2013).

Os linfócitos Th17 representam um subtipo de linfócitos $\mathrm{T}$ efetores importantes na proteção contra infecção por microorganismos extracelulares. Os linfócitos Th17 produzem citocinas IL-22, IL-26, IL-6, TNF- $\alpha$ e citocinas da família IL17. As citocinas da família IL-17 são potentes indutores da inflamação, induzindo à infiltração celular e produção de outras citocinas pró-inflamatórias. A produção desregulada de IL-17 está associada a várias condições autoimunes, como: esclerose múltipla, doença intestinal inflamatória e lúpus (SNYDER-CAPPIONE; NIKOLAJCZYK, 2013).

As células com função imunorreguladora apresentam como característica básica a capacidade de produção de citocinas imunossupressoras, como IL-4, IL-10 e TGF- $\beta$. As células Treg apresentam papel importante na supressão da inflamação (JOSEFOWICZ; LU; RUDENSKY, 2012). Representam 5-10\% do total de linfócitos T CD4 no sangue periférico, podendo ser também isoladas diretamente do timo. A deleção de células Treg causa o desenvolvimento espontâneo de diversas doenças, em modelos de camundongos, incluindo diabetes tipo 1, artrite reumatóide e colites. O fator de transcrição Foxp3 (forkhead transcription factor 3) regula o desenvolvimento e a função dos linfócitos Treg. Essas células possuem a capacidade de suprimir outras células imunes pela produção de IL-10 e TGF $\beta$, que são citocinas anti-inflamatórias clássicas. A presença de TGF- $\beta$ induz a diferenciação de células T CD4 em Treg, porém TGF- $\beta$ juntamente com a citocina IL-6 podem levar a diferenciação de Th17 (DANIELE et al., 2011; MOREAU; CHAUVIN, 2010).

As células T CD8 são conhecidas como células T citotóxicas, e sua principal função é eliminar células infectadas e células não pertencentes ao organismo (nonself cells) através da liberação de enzimas e perforinas, além da liberação de INF-y. Células T CD8 reconhecem antígenos apresentados por moléculas MHC I, que 
estão presentes em todos os tipos celulares, ao contrário das moléculas MHC II que estão presentes apenas em APCs (células dendríticas, macrófagos, monócitos e células B).

A principal função das células B é a produção de anticorpos específicos para diferentes antígenos durante a resposta imune humoral. Para completarem sua ativação, as células B devem interagir com células Th2. Quando o receptor BCR reconhece antígenos livres (células B não requerem a apresentação de antígenos através de moléculas $\mathrm{MHC}$ ), os antígenos são capturados, digeridos e expostos na superfície celular através de moléculas MHC II. As células Th2 podem interagir via TCR com o MHC das células B. Após isso as células Th2 produzem citocinas que causam o completo desenvolvimento de células B e maximizam a produção de anticorpos por essas células - processo chamado "ativação dependente de células T” (LEE; LEE, 2013). As células B também podem ser ativadas via independente de células $\mathrm{T}$, porém esse processo ocorre com menor frequência. Recentemente foi mostrado que células $B$ podem agir como células supressoras. Esse efeito supressivo das células B é similar aos das células Treg na inflamação, com secreção de IL-10, sendo também conhecida como células $B$ reguladoras (B regs) (MAURI, 2010; MAURI; EHRENSTEIN, 2008).

A resposta imunológica frente a patógenos após ativação de receptores TCR/BCR induz uma síntese significativa de novas citocinas, anticorpos e outras proteínas efetoras, bem como a indução de uma rápida proliferação celular e expansão clonal. A sinalização de TCR resulta em uma cascata de fosforilação regulada por proteínas tirosina fosfatases (PTP) e quinases (PTK) levando a uma complexa sinalização. Diversas vias como MAPK e NFКB são ativadas. MAPKs estão envolvidas na regulação do ciclo celular e sobrevivência, podendo também levar a ativação da via de sinalização $N F_{\kappa} B$, na qual é importante na regulação de diversos genes inflamatórios, como a produção de diversas citocinas e moléculas de adesão. Muitos agentes parecem promover a ativação de NFאB em células T como, por exemplo, o forbol de meristado acetato (PALKOWITSCH et al.), o TNF- $\alpha$, o lipopolissacarideo (LPS), ionóforos de cálcio e $\mathrm{H}_{2} \mathrm{O}_{2}$ (GINN-PEASE; WHISLER, 1998).

O PMA, um análogo do diacilglicerol, é capaz de ativar a proteína quinase $\mathrm{C}$ (PKC). A ativação de PKC leva à fosforilação de proteínas adaptadoras, CARMA1, 
Bcl10 e MALT1, que subsequentemente levam a formação de um complexo trimolecular denominado CARMA1/Bcl10/MALT1. Esse complexo recruta proteínas como TRAF6 que levam a ativação de IKKs com consequente fosforilação e degradação de IKB. Como resultado NFKB é liberado e translocado até o núcleo para a regulação gênica de mediadores inflamatórios (GAIDE et al., 2002).

lonóforos de cálcio são capazes de estimular a mobilização de cálcio através das membranas biológicas (SOCs) e abertura de canais dependentes de cálcio (CRAC). O influxo sustentado de cálcio leva à ativação de enzimas dependentes de cálcio como a calmodulina, a calcineurina e a fosfatase serina/treonina que desfosforila resíduos de serina nas proteínas NFAT (Fator Nuclear de Células T ativadas). A desfosforilação provoca uma mudança conformacional na NFAT, permitindo sua translocação ao núcleo. NFAT promove a expressão de genes que

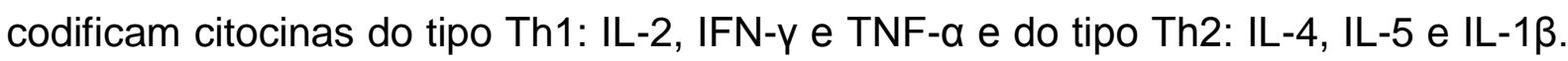
Além disso, alguns trabalhos (PALKOWITSCH et al., 2011) já demonstraram que a calcineurina regula a atividade de NFKB por controlar a formação do complexo proteico CARMA1/Bcl10/MALT1. Mecanicamente, o efeito positivo da calcineurina na formação do complexo CARMA1/Bcl10/MALT1 parece estar relacionado à desfosforilação de Bcl10 (PALKOWITSCH et al., 2011).

Por sua vez, a ativação de NFKB pelo agente LPS (lipopolissacarídeo de bactérias Gram negativas) ocorre através do reconhecimento deste por uma classe de receptores de membrana do tipo de reconhecimento de padrão - receptores Toll like (TLRs) presentes principalmente nas células do sistema imune. A molécula CD14 expressa na superfície celular de alguns leucócitos auxilia os receptores TLRs (especificamente o subtipo TLR4) a reconhecerem a partícula de LPS. O reconhecimento e ativação de TLRs desencadeia a ativação e sinalização da via NFKB (AKIRA; TAKEDA, 2004). Já foram identificados 10 subtipos de TLR em humanos e 12 subtipos funcionais em camundongos (KAWAI; AKIRA, 2010), cada subtipo apresentando uma especificidade diferente na detecção de patógenos. Os TLRs 1, 2, 4, 5, e 6 ocorrem na superfície de APCs e células não apresentadoras de antígenos e reconhecem vários componentes bacterianos (LPS) e fúngicos (KAWAI; AKIRA, 2010; SWAMY et al., 2010). Os TLRs 3, 7, 8 e 9 operam exclusivamente no meio intracelular e são capazes de reconhecer ácidos nucleicos (BLASIUS; BEUTLER, 2010; KAWAI; AKIRA, 2010). Os diferentes TLRs utilizam uma proteína 
adaptadora, o fator de diferenciação mieloide 88 (MyD88), para transcrição e ativação do fator NFKB (AKIRA; TAKEDA, 2004).

O reconhecimento de antígenos pelas células T promove uma reprogramação metabólica nestas células, caracterizado por crescimento rápido, proliferação e aquisição de funções efetoras especializadas. Este é um processo que demanda muita energia. Para as células crescerem e proliferarem, elas devem mudar seu metabolismo catabólico para metabolismo anabólico, pois, diferente das células em repouso, os nutrientes não mais serão utilizados preferencialmente para a manutenção e homeostase celular, mas serão incorporados na biomassa das novas células filhas. Assim, quando as células são ativadas elas passam a utilizar preferencialmente a via glicolítica ao invés da fosforilação oxidativa (CAROMALDONADO; GERRIETS; RATHMELL, 2012).

Mais especificativamente, podemos dizer que diferentes programas metabólicos podem influenciar o desenvolvimento de vários subtipos de células $T$. Por exemplo, células $T$ destinadas a tornarem-se células de memória devem manter ou adotar um metabolismo catabólico, uma característica que constitui seu estado de quiescência e longevidade. Da mesma forma, as células Treg usam predominantemente a fosforilação oxidativa e oxidação de lipídeos mitocondrial para seu desenvolvimento e sobrevivência, enquanto a geração de células Th 17 requerem a glicólise (CARO-MALDONADO; GERRIETS; RATHMELL, 2012).

A ativação de células $T$ leva à sinalização de TCR/ fosfatidilinositol-3-quinase (PI3K) com posterior ativação de Akt através da conversão de fosfatidilinositol-4,5bifosfato $\left(\mathrm{PIP}_{2}\right)$ em fosfatidilinositol-3,4,5- trifosfato $\left(\mathrm{PIP}_{3}\right)$. A Akt promove o metabolismo da glicose por estimular a localização do transportador de glicose Glut1 na membrana plasmática, facilitando o aumento da captação de glicose. Além disso, a Akt aumenta o metabolismo glicolítico por estimular a atividade da hexoquinase e fosfofrutoquinase, duas enzimas limitantes da via glicolítica. A Akt também controla o estado de ativação de mTOR, um sensor do estado nutricional e energético nas células, capaz de modular a síntese proteica regulando a disponibilidade de nutrientes (PETER; WALDMANN; COBBOLD, 2010). Além disso, mTOR apresenta função crucial na determinação da diferenciação de células T CD4 em subtipos efetores e reguladores, o desenvolvimento de células T CD8 de memória e a regulação do tráfego de células $\mathrm{T}$ no organismo (Figura 2). Alguns trabalho (DELGOFFE et al., 2009) evidenciam que células T CD4 deficientes em mTOR não 
conseguem se diferenciar nos subtipos celulares Th1, Th2 e Th17 sob ativação, porém apresentam fenótipo e diferenciação de células T reg.

Figura 2 - Influência do metabolismo energético na diferenciação dos subtipos de células T

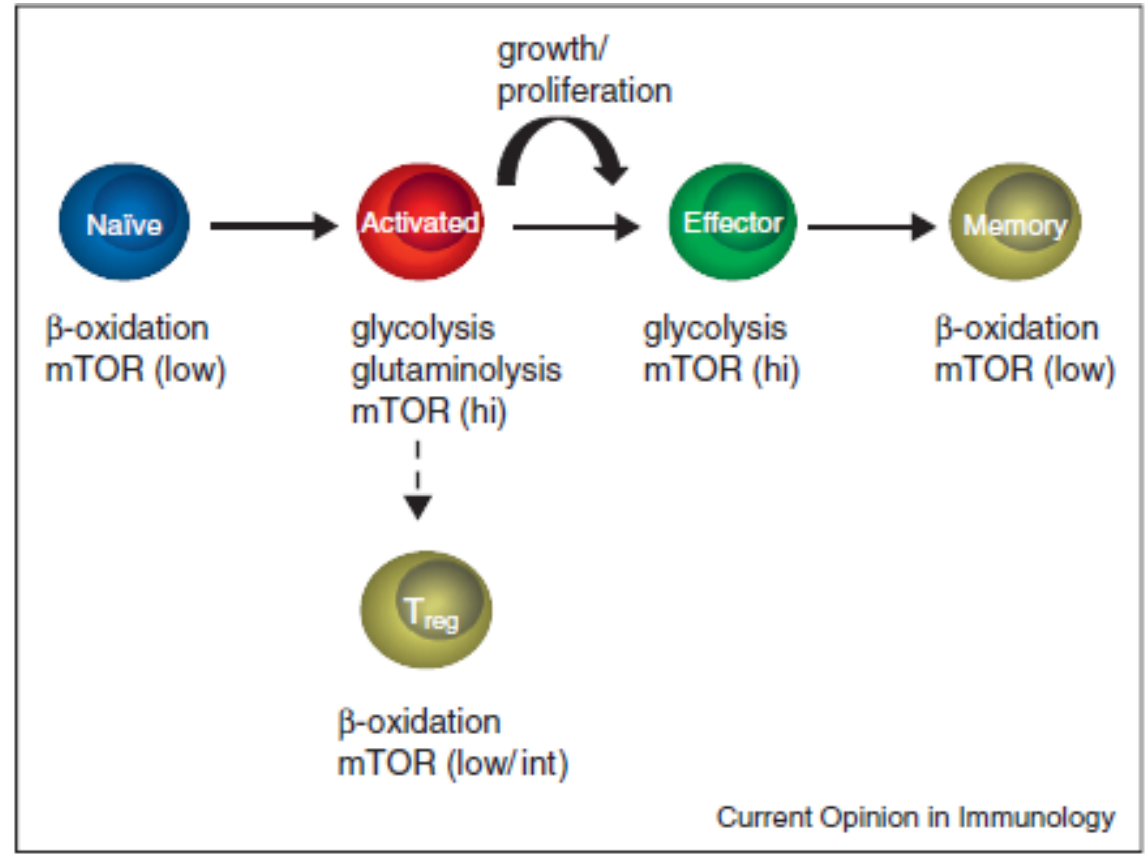

Células T em diferentes estágios de diferenciação exibem fenótipos metabólicos e atividades mTOR distintos. Células T naïve dependem do catabolismo, particularmente a $\beta$-oxidação de lipídeos, para a manutenção da homeostase. Estes também apresentam baixa atividade da via mTOR. Estimulação antigênica ativa mTOR e marcadamente regula positivamente programas anabólicos especialmente glicólise e glutaminólise, enquanto diminui a $\beta$-oxidação de lipídeos. A interação entre mTOR e programas metabólicos contribui para o crescimento e proliferação de células $T$ induzidas por antígeno. Células T efetoras mantêm alto fluxo glicolítico e atividade mTOR, mas a sua diferenciação em células $T$ de memória é acompanhada por uma interrupção do metabolismo anabólico para o catabólico, particularmente com a regulação positiva da $\beta$-oxidação de lipídeos, bem como a regulação negativa da atividade de mTOR. Células T reg também apresentam $\beta$-oxidação de lipídeos mas atividade baixas/intermediária de mTOR. Fonte: Zeng e Hongbo, 2013.

Em geral, a disponibilidade dessas fontes energéticas é importante em diversas vias metabólicas para geração de energia, capacidade proliferativa e sobrevivência dessas células (CARO-MALDONADO; GERRIETS; RATHMELL, 2012). Se a captação de nutrientes é limitada, como nas situações de subnutrição e jejum prolongado, diminui-se o fluxo glicolítico a um nível que compromete a viabilidade celular e membros pró-apoptóticos da família Bcl-2 tornam-se ativados, promovendo morte celular. Por outro lado, o excesso de nutrientes e glicose 
encontrado no estado de obesidade pode promover uma hiperativação dessas células levando a quadros patológicos. Dessa forma uma fina regulação da captação de nutrientes é necessária para manter a homeostase imunológica (CAROMALDONADO; GERRIETS; RATHMELL, 2012).

Todo esse processo de sinalização celular demanda alta quantidade de energia e com isso ocorre a ativação da clássica cadeia respiratória mitocondrial, com consequente formação de espécies reativas de oxigênio (EROs).

EROs são moléculas derivadas do oxigênio, que possuem elétrons desemparelhados na sua última camada de valência, o que lhes confere um caráter altamente reativo em tecidos biológicos (VINCENT; TAYLOR, 2006). O ânion superóxido $\left(\mathrm{O}_{2}^{-*}\right)$, o radical hidroxila $\left({ }^{\circ} \mathrm{OH}\right)$ e o óxido nítrico (NO') são alguns exemplos. Existem outros compostos, que, apesar de não apresentarem elétrons desemparelhados são reativos, entre eles o peróxido de hidrogênio $\left(\mathrm{H}_{2} \mathrm{O}_{2}\right)$, o cátion nitroso $\left(\mathrm{NO}^{+}\right)$, o ânion nitroxila (NO-) e o peroxinitrito (OONO-) (DROGE, 2002). O radical hidroxila é muito reativo e propenso a atacar todas as moléculas biológicas. O ânion superóxido e o peróxido de hidrogênio são menos reativos em relação ao radical hidroxila, mas quando produzidos em excesso também podem induzir danos celulares. O ânion superóxido pode reagir com o óxido nítrico e formar peroxinitrito, o qual pode oxidar grupos sulfidrila (LIN; LIN-SHIAU, 2006) e também se decompor e gerar radicais hidroxilas (VINCENT; TAYLOR, 2006).

A geração de ERO, independentemente da sua origem, pode desempenhar um papel importante na célula $\mathrm{T}$ em vários processos vitais incluindo proliferação, sinalização e morte celular por apoptose (KAMATA; HIRATA, 1999; VALKO et al., 2007).

O complexo NADPH oxidase e a cadeia transportadora de elétrons mitocondrial são as principais vias geradoras de ERO em diversos tipos celulares, incluindo as células T (WILLIAMS; KWON, 2004). Células T expressam níveis muito baixos de NADPH oxidase, sugerindo que outras células determinam a resposta de células T através da produção de EROs (GELDERMAN et al., 2006). Um estudo demonstrou baixos níveis de NADPH oxidase em células T (JACKSON et al., 2004) e que as células apresentadoras de antígenos (APC) interagem com as células T durante a apresentação de antígenos e expressam $\mathrm{NOX}_{2}$ (uma isoforma do complexo NADPH oxidase) que, por sua vez afetam a resposta de células $T$ através da produção de EROs. De fato, EROs produzidas durante a apresentação de 
antígenos afetam a resposta imune (MATSUE et al., 2003; TSE et al., 2007) por interferir na via de sinalização intracelular (DEYULIA et al., 2005; FORMAN; TORRES, 2001).

Existem evidências da participação do peróxido de hidrogênio no processo de ativação dos linfócitos T e B. O peróxido de hidrogênio pode atuar como segundo mensageiro no linfócito $B$ inibindo a proteína fosfatase (PTP) que regula negativamente a ativação dos linfócitos, permitindo assim, que as ITAMs, domínios intracelulares do receptor de célula $B(B C R)$, sejam fosforiladas e ativadas (RETH, 2002). Outras proteínas podem ser oxidadas e, portanto, alteradas pela produção de peróxido de hidrogênio entre elas os fatores de transcrição como p53, Jun, Fos e $\mathrm{NF}_{\kappa} \mathrm{B}$. A oxidação destes fatores de transcrição pode inibir ou ativar sua atividade transcricional (SUN; OBERLEY, 1996). Além disso, existe a possibilidade do peróxido de hidrogênio oxidar diretamente alguns componentes do receptor e, portanto, gerar agregação, cross-linking ou mudanças conformacionais que levam à sua ativação (WIENANDS; LARBOLETTE; RETH, 1996).

As EROs também possuem papel benéfico atuando como parte da defesa do organismo contra microorganismos (BENDICH, 1993; KNIGHT, 2000). As células do sistema imunológico utilizam EROs como a primeira linha de defesa contra patógenos bacterianos e virais. Por exemplo, uma grande quantidade de espécies reativas de oxigênio é produzida por macrófagos e neutrófilos ativados durante a resposta inflamatória (BENDICH, 1993; HALLIWELL; GUTTERIDGE, 1990; KNIGHT, 2000). Entretanto, as EROs produzidas por fagócitos para ajudar no combate de agentes invasores, podem ser prejudiciais para as células e tecidos do organismo (MILLER; BRITIGAN, 1995), devido a sua capacidade de reagir e alterar macromoléculas biológicas incluindo ácidos nucleicos, proteínas, carboidratos e lipídeos, resultando em dano celular e tecidual do organismo (WINTERBOURN; HAMPTON, 2008).

Outros tipos de células imunes expostas às EROs são os linfócitos $\mathrm{T}$ e $\mathrm{B}$. Os linfócitos estão expostos tanto ao estresse oxidativo endógeno como também ao exógeno e parecem ser bastante sensíveis à mudança do estado redox. Estudos têm demonstrado que linfócitos do sangue periférico humano são mais sensíveis a agentes oxidantes, como o peróxido de hidrogênio, apresentando mais danos (rupturas das fitas do DNA) do que neutrófilos e monócitos (EL-HAG et al., 1986; SCHRAUFSTATTER et al., 1988; SEAGER et al., 2012). Alterações no DNA e 
em outras moléculas celulares devem ser mantidas dentro de uma população de linfócitos, pois tais alterações sofridas em um local inflamatório podem ter implicações para a integridade das respostas imunitárias subsequentes (BUTTKE; SANDSTROM, 1994; SEAGER et al., 2012).

A capacidade de lidar com o dano oxidativo induzido por EROs dependerá de mecanismos de proteção fornecidos pela célula (LARBI; KEMPF; PAWELEC, 2007). Como um mecanismo de defesa ao aumento de EROs, o organismo produz uma série de antioxidantes endógenos capazes de sequestrar EROs nocivas com o objetivo de manter um ótimo equilíbrio oxidante e antioxidante, mantendo assim a função celular normal. A família de enzimas antioxidantes conhecidas como superóxido dismutase (SOD) é considerada a primeira linha de defesa contra a toxicidade de EROs. Três diferentes isotipos da enzima superóxido dismutase (SOD) têm sido caracterizados em eucariontes: uma forma contendo cobre e zinco (SOD$\mathrm{Cu} / \mathrm{Zn}$ ) localizada no citosol, uma forma contendo manganês (SOD-Mn) presente na mitocôndria e uma forma contendo cobre e zinco (SOD-EC) na matriz extracelular (LIMON-PACHECO; GONSEBATT, 2009). A SOD-EC é a SOD menos abundante nos tecidos, mas é a principal SOD presente nos fluidos extracelulares como 0 plasma e matriz extracelular (GOTTFREDSEN et al., 2013; MARKLUND, 1984). O ânion superóxido é dismutado pela SOD, formando $\mathrm{H}_{2} \mathrm{O}_{2}$. $\mathrm{O} \mathrm{H}_{2} \mathrm{O}_{2}$ é então convertido a água pelas enzimas catalase (CAT) e glutationa peroxidase (GPx) (LIMONPACHECO; GONSEBATT, 2009). A GPx reduz peróxido de hidrogênio e hidroperóxidos a partir da oxidação da glutationa reduzida (GSH) à glutationa oxidada (GSSG) (SCHAFER; BUETTNER, 2001). A redução da glutationa oxidada (GSSG) é realizada pela enzima glutationa redutase (GR) na presença do cofator $\mathrm{NADPH}$, que pode ser fornecido através da atividade da enzima glicose-6-fosfatodesidrogenase (G6PDH) na via das pentoses (CIRCU; AW, 2010) (Figura 3).

Contudo, em condições de alto estresse oxidativo, a capacidade desses antioxidantes na eliminação de EROs é frequentemente ultrapassada e, por conseguinte, fontes alimentares de antioxidantes ou drogas são necessárias. Os antioxidantes mais amplamente utilizados na dieta são: vitaminas C e E, carotenóides, polifenóis (flavonoides), cobre, zinco, manganês e selênio (POWERS et al., 2004). Níveis de EROs estão aumentados na obesidade e síndrome metabólica e a redução destes compostos foi observada com a perda de peso (ROBERTS et al., 2006; VINCENT; TAYLOR, 2006). 
Figura 3 - Integração dos sistemas de defesa enzimáticos e relação com enzimas metabólicas

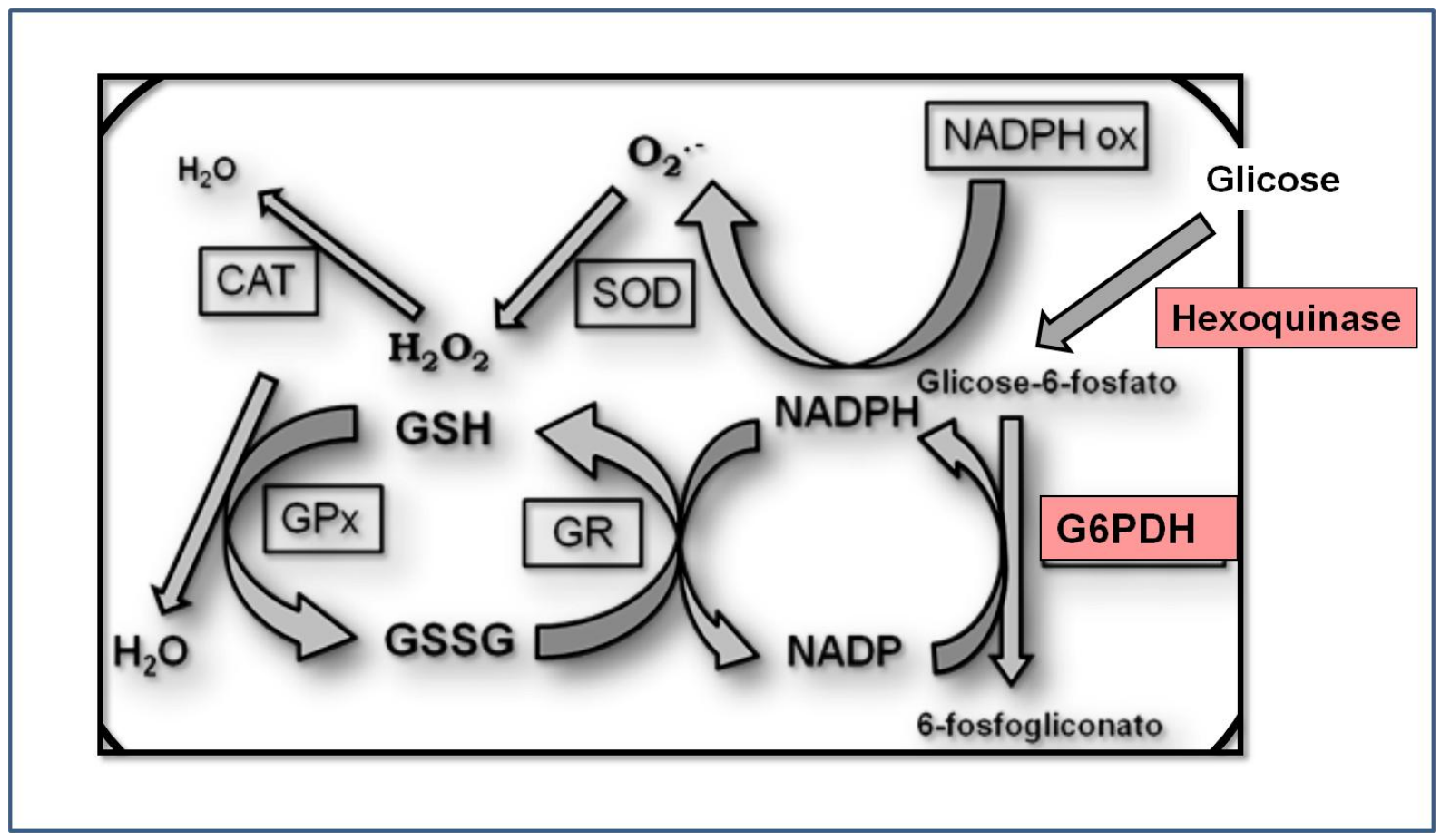

Por meio da reação de dismutação, a superóxido dismutase (SOD) catalisa a geração de peróxido de hidrogênio $\left(\mathrm{H}_{2} \mathrm{O}_{2}\right)$ a partir do radical superóxido $\left(\mathrm{O}_{2}{ }^{-}\right.$. As enzimas catalase (CAT) e glutationa peroxidase (GPx) se integram para impedir o acúmulo de $\mathrm{H}_{2} \mathrm{O}_{2}$ que, apesar de não ser um radical livre, é igualmente reativo e capaz de promover danos potenciais. A GPx reduz $\circ \mathrm{H}_{2} \mathrm{O}_{2}$ a água, no entanto o faz à custa da conversão da glutationa reduzida (GSH) em oxidada (GSSG), essa última promove ação oxidante em função da ligação dissulfeto existente em sua estrutura. Assim, é de extrema importância a ação da glutationa redutase (GR), responsável pela recuperação da glutationa reduzida (GSH), possibilitando a manutenção da integridade do ciclo redox da glutationa e, consequentemente, do equilíbrio adequado entre os sistemas de defesa enzimáticos. A recuperação de GSH a partir da GR necessita da presença do co-fator NADPH. O NADPH pode ser fornecido através da atividade da glicose-6-fosfato-desidrogenase (G6PDH), enzima pertencente à via das pentoses e que catalisa a conversão de glicose-6-fosfato em 6-fosfogliconato. A glicose-6-fosfato é oriunda da fosforilação da glicose realizada pela enzima hexoquinase, primeira enzima pertencente à via glicolítica.

\subsection{Conceito, epidemiologia e caracterização da obesidade}

A obesidade é uma doença crônica que está se tornando um sério problema de saúde no mundo todo, capaz de afetar a saúde de indivíduos de todas as idades e classes sociais (AHMAD; VARGA; FRANKS, 2013; HU; MALIK, 2010; NGUYEN; EL-SERAG, 2010). A prevalência e a incidência da obesidade são crescentes. Calcula-se que em 2015, aproximadamente 2,3 bilhões de adultos terão sobrepeso e 700 milhões serão obesos (WHO, 2009). Com base nestas projeções a Organização Mundial da Saúde (do inglês World Health Organization - WHO) passou a considerá- 
la uma epidemia global (WHO, 1997; 2002; 2009). Estima-se que aproximadamente 1 bilhão de adultos em todo o mundo apresentem obesidade (IMC $\geq 30 \mathrm{~kg} / \mathrm{m}^{2}$ ) ou sobrepeso (IMC entre 25 e $30 \mathrm{~kg} / \mathrm{m}^{2}$ ) o que equivale a aproximadamente $28 \%$ da população mundial. Com base em tais dados, a WHO fez projeções para um futuro próximo, que apontam para prevalências maiores do que 50\% nos Estados Unidos da América (EUA) e maiores do que 25\% no Brasil em 2025 (HASLAM; JAMES, 2005).

A etiologia da obesidade é complexa e multifatorial, resultando da interação de genes, ambiente, estilo de vida e fatores emocionais (BARTOLOMUCCI et al., 2009). A vida moderna é um potente estímulo para o desenvolvimento da obesidade, pois os indivíduos tendem a aumentar a ingestão calórica e a diminuir o gasto energético. $\mathrm{O}$ aumento da ingestão energética pode ser explicado pelas mudanças comportamentais ocorridas nas últimas décadas, como transformações no padrão alimentar associado aos baixos índices de atividade física observados na sociedade, em consequência do processo de modernização e globalização (FANTUZZI; MAZZONE, 2007; FUKUHARA et al., 2005; MATSUZAWA; FUNAHASHI; NAKAMURA, 2011).

A obesidade não é uma doença nova, porém é um problema crescente na atualidade e as consequências do excesso de peso à saúde têm sido demonstradas em diversos trabalhos (CASAZZA et al., 2013; MATSUZAWA; FUNAHASHI; NAKAMURA, 2011; PI-SUNYER, 1991; VAN ITALLIE, 1985). Ela é fator de risco para hipertensão arterial (LOPES; EGAN, 2006), hipercolesterolemia (ROSSI et al., 2013), diabetes mellitus (LAU; TEOH, 2013), doenças cardiovasculares (MATSUZAWA; FUNAHASHI; NAKAMURA, 2011; MYKKANEN; LAAKSO; PYORALA, 1992), algumas formas de câncer (AMADOU; HAINAUT; ROMIEU, 2013; HOLMBERG, 2013), esteatose hepática, cálculos na vesícula biliar e osteoartrite (KOPELMAN, 2007; SHOELSON; HERRERO; NAAZ, 2007). A incidência destas doenças na obesidade é responsável por uma demanda crescente nos sistemas de saúde em todo o mundo (COMMITTEE ON DIET AND HEALTH, 1989; DARNTON-HILL; NISHIDA; JAMES, 2004).

Como resposta às alterações na disponibilidade de nutrientes, o tecido adiposo pode responder de forma rápida e dinâmica através da hipertrofia e hiperplasia dos adipócitos, cumprindo assim um papel importante na homeostase energética do corpo inteiro (SUN et al., 2011). O tecido adiposo branco é o principal 
reservatório corporal para o excesso de calorias ingeridas. Além de armazenamento de nutrientes sob a forma de triacilgliceróis, o tecido adiposo branco pode atuar como um isolante térmico e também proteger órgãos internos de traumas mecânicos (TRAYHURN, 2007).

Atualmente o tecido adiposo é reconhecido como uma fonte de hormônioschave que desempenham um papel importante na regulação do balanço energético em todo o organismo (KOPELMAN, 2007; MATSUZAWA; FUNAHASHI; NAKAMURA, 2011). Além das funções citadas anteriormente, vários trabalhos apontam a capacidade dos adipócitos em secretar uma variedade de substâncias com funções parácrinas, autócrinas e endócrinas, conhecidas como adipocinas. As adipocinas são altamente diversificadas em termos de estrutura e função biológica. Elas incluem citocinas clássicas, fatores de crescimento e proteínas do sistema complemento, mas também proteínas envolvidas na regulação da pressão sanguínea, hemostasia vascular, metabolismo lipídico, homeostase da glicose e angiogênese. Entre estas destacamos a leptina, adiponectina, resistina, TNF-alfa, IL6, proteína quimiotática de monócitos (MCP-1), inibidor do ativador do plasminogênio-1 (PAl-1), angiotensinogênio, visfatina, proteína ligadora de retinol-4, amilóide A sérica (SAA) entre outros (KOPELMAN, 2007; TRAYHURN, 2007). A leptina e a adiponectina são consideradas adipocinas primárias porque parecem ser produzidas principalmente pelos adipócitos.

Hoje se sabe que a produção de adipocinas parece estar alterada em indivíduos obesos, os quais normalmente apresentam concentrações reduzidas de adiponectina e elevadas de leptina, contribuindo para o surgimento de transtornos metabólicos como o diabetes e a dislipidemia aterogênica (diminuição de HDLcolesterol e aumento de triglicérides) (FANTUZZI; MAZZONE, 2007; FUKUHARA et al., 2005; KOPELMAN, 2007; SUN et al., 2011).

A leptina circulante age como sinalizador informando ao sistema nervoso central a respeito da quantidade de energia estocada e, assim, suprimindo a ingestão alimentar e induzindo ao gasto energético. Os níveis adequados de leptina permitem o controle do gasto energético nos processos de reprodução, remodelamento e crescimento tecidual, funcionamento do sistema nervoso autônomo e na resposta imune inata ou adaptativa (SCHWARTZ et al., 2000). Ao contrário, a falta da sinalização da leptina, como ocorre em mutações do seu receptor ou da própria leptina em roedores (camundongos $\mathrm{db} / \mathrm{db}$ e ob/ob, 
respectivamente) ou em humanos, resulta no aumento da ingestão alimentar e redução do gasto energético, podendo levar ao quadro de obesidade. $O$ aumento circulante da leptina no indivíduo obeso está relacionado com a resistência à leptina que se desenvolve nesse indivíduo, além do aumento do tecido adiposo, que favorece uma maior liberação dessa adipocina (MARTIN; QASIM; REILLY, 2008). Atualmente há duas hipóteses bem aceitas para o desenvolvimento da resistência à leptina: a primeira seria a falha da leptina circulante em alcançar os alvos no hipotálamo, e a segunda, a existência de defeitos na expressão de receptores para a leptina $(\mathrm{ObRb})$, assim como inibição intracelular de sua cascata de sinalização (MARTIN; QASIM; REILLY, 2008).

A adiponectina está presente na circulação de humanos e camundongos saudáveis em altas concentrações. Sua expressão é regulada de forma relativamente aguda (4-6 horas) por meio da alimentação ou jejum. A adiponectina é a adipocina bem mais descrita na literatura, por ter sido identificada como capaz de aumentar a sensibilidade à insulina em tecidos periféricos. Seus níveis decrescem no indivíduo obeso, devido a estes indivíduos apresentaram aumento circulante de TNF-a e este, por sua vez, é capaz de diminuir a produção de adiponectina, exercendo um mecanismo contrarregulatório (WHITEHEAD et al., 2006).

\subsection{Obesidade e inflamação}

Muitos trabalhos recentes introduzem o conceito de que a obesidade desencadeia a liberação crônica e de baixo grau de alguns mediadores inflamatórios envolvidos no aparecimento das diversas complicações associadas à obesidade (MATHIS; SHOELSON, 2011). De forma geral, a inflamação representa uma série de respostas celulares e moleculares que servem para defender o organismo de infecções ou outros insultos. Sua desregulação tem sido responsável pelo surgimento de muitas doenças como artrite reumatóide, aterosclerose, asma entre outras doenças autoimunes (CHOY; PANAYI, 2001; DE CATERINA; ZAMPOLLI, 2004; HANSSON, 2005). Durante a inflamação as principais células ativas são as células imunes, que podem ser basicamente divididas em células com atividade próe anti-inflamatória. A quantidade relativa e as funções dessas células controlam fortemente o processo inflamatório (LEE; LEE, 2013). Por exemplo, quando células são infectadas por bactérias ou fungos, elas liberam sinais que são percebidos por 
células do sistema imune, particularmente os neutrófilos. Os neutrófilos então migram até o local infectado, e liberam diversas quimiocinas que atraem outras células imunes até o local infectado. Os macrófagos são os primeiros a serem recrutados com posterior migração dos linfócitos. Então, as células imunes matam e removem as células infectadas e após a resolução da inflamação, processos de reparo celular e tecidual são iniciados no local (LEE; LEE, 2013). Além disso, a inflamação aguda clássica apresenta alguns sinais flogísticos conhecidos como sinais cardinais que sinalizam sua presença. Entre esses sinais temos: dor, calor, rubor, tumor e, em alguns casos, a perda da função celular ou tecidual. A inflamação também é caracterizada pelo aumento dos níveis de citocinas na circulação e no sítio inflamatório, que estão relacionados com 0 aumento das células imunes infiltradas no sítio inflamatório (LEE; LEE, 2013).

Quando a inflamação é induzida sem a presença de um quadro de infecção, diz-se que há uma inflamação estéril ou metainflamação. Neste caso, as células são principalmente mortas por necrose e produzem DAMPs (moléculas padrão associadas a danos) como HMGB1 (proteína não-histona mais abundante no núcleo celular) e dsDNA (fita dupla de DNA) que se ligam a receptores tais como TLR, iniciando assim a ativação de vias de sinalização inflamatórias.

Na obesidade a produção de mediadores inflamatórios é desencadeada pela ativação de vias de sinalização semelhantes ao da inflamação clássica (IKKß/NFKB e JNK), porém difere desta última por apresentar uma liberação crônica de baixo grau desses mediadores com baixa produção de citocinas circulantes e ausência dos sinais flogísticos (LEE; LEE, 2013).

Através da expressão de receptores TLRs, adipócitos são sensíveis a ligantes microbianos e produtos liberados do hospedeiro em uma situação de lesão tecidual (SCHAFFLER; SCHOLMERICH, 2010). O “Transbordamento lipídico" também observado no indivíduo obeso leva à ativação de uma cascata inflamatória via TLRs, mediadores de estresse de retículo e outras vias inflamatórias. Além disso, adipócitos expressam receptores para TNF-a (CAWTHORN; SETHI, 2008). Em resposta a sinais inflamatórios como o aumento da expressão de TNF- $\alpha$ no tecido adiposo do obeso, a ação da insulina nos adipócitos é inibida, e os adipócitos secretam uma grande quantidade de mediadores inflamatórios (OUCHI et al., 2011). Com isso, o aumento da liberação de mediadores inflamatórios no indivíduo obeso favorece a infiltração de células imunes no tecido adiposo. 
A expressão de citocinas pró-inflamatórias e a infiltração de células imunes no tecido adiposo ocorrem de forma gradual. Camundongos geneticamente obesos ou induzidos à obesidade após três semanas de dieta hiperlipídica apresentaram um aumento na expressão de genes relacionados a macrófagos no tecido adiposo, principalmente, durante o início da resistência à insulina (XU et al., 2003). O mesmo trabalho relacionou que durante a hipertrofia dos adipócitos há um aumento na expressão de genes de resposta inflamatória e que o desenvolvimento da resistência à insulina intensifica este quadro. Portanto, uma vez que macrófagos e outras células do sistema imune estejam presentes e ativos no tecido adiposo de obesos, elas, em conjunto com os adipócitos e outros tipos celulares, perpetuam um ciclo vicioso de recrutamento de macrófagos, produção de citocinas inflamatórias e comprometimento da função dos adipócitos (GREGOR; HOTAMISLIGIL, 2011).

Diversos trabalhos demonstram que a expressão de citocinas próinflamatórias é capaz de interromper a sinalização da insulina em tecidos periféricos como o tecido adiposo e muscular, por diferentes mecanismos (HOWARD; FLIER, 2006). As citocinas são capazes de provocar a ativação de serina-quinases, especialmente a IKK e a JNK, entre outras moléculas como a iNOS (óxido nítrico sintase induzível), que por sua vez fosforilam moléculas sinalizadoras como o IRS-1 e IRS-2 (substratos do receptor de insulina) em resíduos serina, inibindo dessa forma a sinalização da insulina (PAULI et al., 2009). A ativação dessas quinases na obesidade ressalta a interligação entre as vias imunes e metabólicas, pois estas são as mesmas quinases (principalmente a JNK e a IKK) que são ativadas na resposta imune inata ativada pelos receptores TLRs após sua ligação com 0 lipopolissacarídeo (LPS), peptideoglicano e outros produtos microbianos (MEDZHITOV, 2001). Citocinas pró-inflamatórias como o TNF- $\alpha$ e a IL-1 $\beta$ ativam a JNK e a IKK através dos mecanismos clássicos mediados por seus receptores (AKIRA; UEMATSU; TAKEUCHI, 2006). A ligação de TNF- $\alpha$ ao seu respectivo receptor desencadeia uma gama de efeitos intracelulares, como o recrutamento de TRAF-2 (fatores associados ao receptor de TNF- $\alpha$ ) ao domínio intracelular do receptor, levando a fosforilação de IKKs e JNK, com ativação dos fatores de transcrição NFKB e AP-1, respectivamente. Por sua vez, a ligação de IL-1 $1 \beta$ ao seu receptor (IL-1 $\beta R$ ), promove o recrutamento da proteína adaptadora MyD88 e da quinase serina/treonina IRAK, levando também à ativação dos fatores de transcrição NFKB e AP-1. 
Assim, os mediadores inflamatórios induzidos pela obesidade representam um tipo diferente de processo inflamatório, sendo o resultado da supernutrição e ativação de vias de estresse nas células, que conduzem a uma homeostase metabólica anormal (altas concentrações de lipídeos, ácidos graxos, glicose e espécies reativas de oxigênio) (LEE; LEE, 2013).

Além disso, mudanças na composição celular do tecido adiposo, incluindo ajustes no número, fenótipo e localização de múltiplos subtipos de células imunes, também ocorrem na obesidade e contribuem para a liberação de mediadores inflamatórios (Figura 4). Em indivíduos magros o tecido adiposo apresenta um ambiente anti-inflamatório, no qual macrófagos residentes com fenótipo M2 produzem fatores como IL-10 e TGF- $\beta$ (FUJISAKA et al., 2009; KAMEl et al., 2006; LUMENG et al., 2007; MOSSER; EDWARDS, 2008; ODEGAARD et al., 2007). Há também o predomínio de eosinófilos e células Treg, as quais produzem IL-10, IL4 e IL-13 e "direcionam" para a resposta Th 2, que previne o indivíduo do quadro de inflamação e resistência à insulina (CHAWLA; NGUYEN; GOH, 2011).

Ao contrário deste, no tecido adiposo de indivíduos obesos (Figura 4), macrófagos residentes e infiltrados demonstram fenótipo $M 1$ com produção de diversos fatores inflamatórios, incluindo o TNF- $\alpha$, IL-6 e metaloproteinases (FUJISAKA et al., 2009; KAMEl et al., 2006; LUMENG et al., 2007; WEISBERG et al., 2003). Também ocorre o predomínio de mastócitos, linfócitos T CD8 e T CD4+, na qual todos produzem TNF- $\alpha$, IFN- $\gamma$ e induzem a polarização de macrófagos para o subtipo M1. Assim, essas células residentes do tecido adiposo "direcionam" para uma resposta celular Th 1, caracteristicamente inflamatória. A resposta Th1 no tecido adiposo promove inflamação e resistência insulínica, levando a mobilização de nutrientes via gliconeogênese, hiperglicemia e lipólise (CHAWLA; NGUYEN; $\mathrm{GOH}, 2011$ ), demonstrando haver uma interelação entre as vias metabólicas e o sistema imunológico já que a resposta imune é altamente dependente de energia (WOLOWCZUK et al., 2008). 
Figura 4 - Composição celular do tecido adiposo de um indivíduo saudável e de um indivíduo obeso

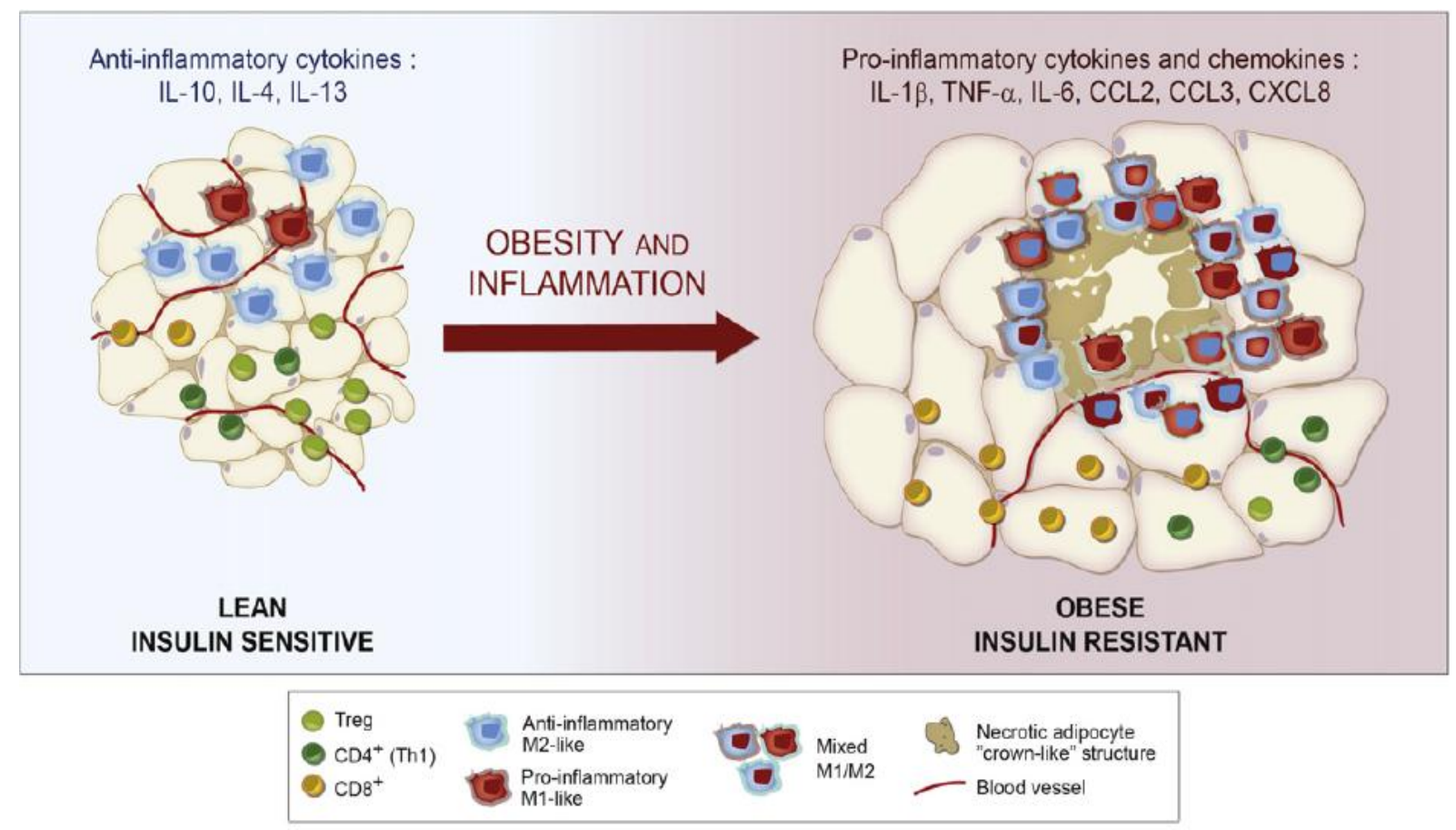

Obesidade resulta na liberação de mediadores pró-inflamatórios e mudanças no número e fenótipo de células imunes no tecido adiposo. O tecido adiposo de um indivíduo saudável apresenta quantidades elevadas de células com caráter anti-inflamatório como macrófagos M2 e células Treg, sendo o microambiente dominado por citocinas anti-inflamatórias (IL-10, IL-4, IL-13). O excesso de nutrientes a longo tempo, pode levar à apoptose e morte por necrose de adipócitos, bem como diminuição da vascularidade. Na obesidade, o tecido adiposo apresenta uma mistura de fenótipos de macrófagos M1/M2, mais células T CD8 do que células T CD4 e poucas células Treg. As células efetoras produzem citocinas pró-inflamatórias e quimiocinas (IL-1 $\beta$, TNF- $\alpha$, IL-6, CCL2, CCL3, CXL8).

Fonte: Shu et al. 2013.

Há evidências crescentes de que a leptina e a adiponectina além de suas funções metabólicas, regulam a resposta imune humoral e celular (AHIMA et al., 2000). Normalmente a leptina atua estimulando a liberação de citocinas próinflamatórias por monócitos. Estas por sua vez estimulam os linfócitos $\mathrm{T}$, os quais respondem com a produção de IL-2 e IFN-y, caracteristicamente citocinas de resposta Th1 (MUNOZ; MAZURE; CULEBRAS, 2004; OTERO et al., 2005; SANCHEZ-MARGALET et al., 2003). Entretanto, na obesidade, pode ocorrer uma alteração nesta regulação, existindo uma proliferação linfocitária anormal com uma redução na capacidade funcional dos linfócitos (MARTI; MARCOS; MARTINEZ, 2001), tendo em vista que a leptina é um modulador da ativação dos mesmos e se encontra elevada nos indivíduos obesos (SANCHEZ-MARGALET et 
al., 2003). Além disso, há trabalhos que evidenciam que a leptina pode atuar como um sinalizador negativo para a expansão de células T reguladoras (Treg) (DE ROSA et al., 2007).

Em relação à adiponectina, podemos dizer que se caracteriza por apresentar ações anti-inflamatórias em uma variedade de tecidos. Essas ações incluem efeitos diretos em monócitos e macrófagos, células endoteliais, hepatócitos e células musculares. A indução de IL-10 por essa adipocina suprime a produção de TNF- $\alpha$ e IL-6 pelo tecido adiposo e células imunes (WHITEHEAD et al., 2006). Alguns trabalhos já demonstraram seu efeito sobre as células $T$, experimentos com cocultura de células $T$ e células dendríticas tratadas com adiponectina mostraram redução na proliferação de células $T$ e na produção de IL-2 e aumento na porcentagem de células T reguladoras (TSANG et al., 2011) sugerindo assim que a adiponectina poderia controlar a homeostase das células Treg.

A suscetibilidade de adquirir infecções, a incapacidade de combatê-las, a prevalência de doenças auto-imunes e o desenvolvimento de doenças crônicas inflamatórias, estão elevadas nos indivíduos obesos e deve-se em grande parte à hiperativação das células imunes nesses indivíduos, que pode levar à defeitos ou alterações na funcionalidade dessas células acarretando assim prejuízos na resposta imunológica (GRANT et al., 2013). Níveis aumentados de estresse oxidativo também estão presentes nos indivíduos obesos, e os principais fatores contribuintes são a hiperglicemia, ácidos graxos e triacilglicerol elevados, hiperleptinemia e defesas antioxidantes inadequadas (VINCENT; TAYLOR, 2006). Como em geral na obesidade o padrão da dieta muda, inserindo-se mais gordura e carboidratos em detrimento de frutas, verduras e legumes, as defesas antioxidantes de fonte alimentar se encontram inadequadas. Além disso, as concentrações plasmáticas de vitaminas, minerais e a atividade de enzimas antioxidante são menores na obesidade. Essas características, aliadas a produção elevada de EROs contribui para um maior estresse oxidativo (VINCENT; TAYLOR, 2006).

\subsection{Chá Verde}

Após a água, o chá é a bebida mais consumida em todo o mundo (CHACKO et al., 2010; GRAHAM, 1992). A planta $C$. sinensis é cultivada em em regiões tropicais e subtropicais, sendo amplamente cultivada no sul da Ásia, incluindo China, 
Índia, Japão, Tailândia, Sri Lanka e Indonésia. O chá destas plantas que pertence à família Theaceae tem duas variedades principais: a Camellia sinensis var. sinensis, uma pequena planta de folhas originária da China, cultivada em vários países do Sudeste da Ásia experimentando um clima frio, e a Camellia sinensis var. assamica, uma grande árvore de folhas descobertas na região de Assam na Índia que foi introduzida em vários países com clima subtropical. A variedade assâmica contém grandes quantidades de taninos e catequinas e é particularmente utilizada para o preparo do chá preto, enquanto que o chá da var. sinensis conta para a maioria da produção do chá verde. A composição das folhas do chá depende de uma variedade de fatores incluindo clima, estação do ano, processo utilizado na horticultura, além do tipo e idade da planta (SAITO et al., 2009).

Dependendo do processo de produção utilizado, as folhas da $C$. sinensis (Figura 5) são a base para a produção de três principais tipos de chás: chá verde, oolong e preto, sendo que a diferença entre estes depende do grau de inativação das enzimas foliares durante o processamento. O chá verde é produzido a partir das folhas frescas da planta, após uma rápida inativação da enzima polifenol oxidase, pelo emprego de vaporização e secagem, o que mantém preservado seu teor de polifenóis e o torna mais rico em catequinas que os demais. O chá oolong ou "parcialmente oxidado" é obtido após as folhas ficarem em repouso por duas a quatro horas, sendo depois aquecidas para que o processo oxidativo seja interrompido. Já o chá preto é derivado de folhas envelhecidas pela oxidação aeróbica das catequinas catalisada enzimaticamente (CABRERA; ARTACHO; GIMENEZ, 2006; DE MEJIA; RAMIREZ-MARES; PUANGPRAPHANT, 2009; SUN et al., 2011). Para produzir o chá preto, as folhas frescas são desidratadas, o que diminui seu teor de umidade, até que seu peso se aproxime de $55 \%$ do peso da folha original. As folhas secas são em seguida, enroladas e trituradas, iniciando a fermentação de polifenóis. Esta fermentação converte as catequinas em teaflavinas, tearubiginas, o que conseqüentemente diminui o conteúdo de catequinas (CRESPY; WILLIAMSON, 2004). 
Figura 5 - Planta Camellia sinensis.

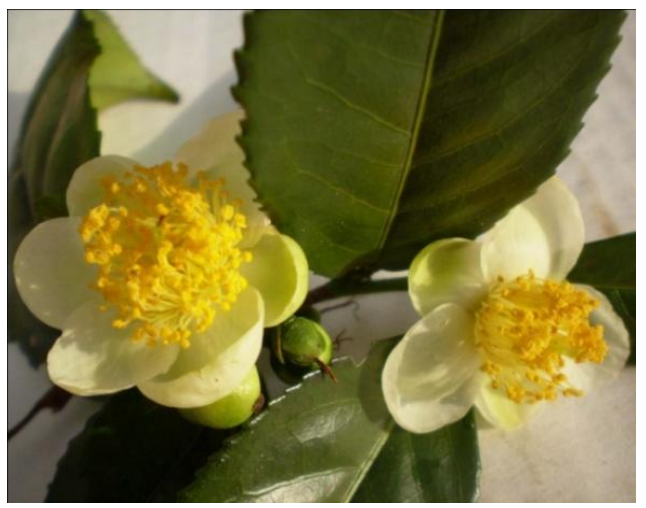

Fonte: disponível em: <http://www.toptropicals.com/camellia sinensis/>. Acesso em: 23 dez.2013.

Em relação à composição química do chá verde, as proteínas perfazem de $15-20 \%$ do peso seco sendo que as enzimas constituem uma fração importante; os aminoácidos correspondem a $1-4 \%$ do peso seco entre eles a teanina ou $5-\mathrm{N}$ etilglutamina, ácido glutâmico, triptofano, glicina, serina, ácido aspártico, tirosina, valina, leucina, treonina, arginina e lisina são os mais abundantes; os carboidratos representam $5-7 \%$ do peso seco do extrato sendo os principais a celulose, pectinas, glicose, frutose e sacarose; os minerais e oligoelementos (5\% peso seco) como cálcio, magnésio, cromo, ferro, manganês, cobre, zinco, selênio, sódio, fósforo, cobalto, estrôncio, níquel, potássio, flúor, alumínio e vestígios de lipídios (ácidos linoléico e a-linolênico), esteróis (estigmasterol), vitaminas $(B, C, E)$, cafeína, teofilina, pigmentos (clorofila, carotenóides), e compostos voláteis (aldeídos, alcoóis, ésteres, lactonas, hidrocarbonetos). O chá verde contém também polifenóis, que incluem flavanóis, flavandióis, flavonóides e ácidos fenólicos, como o ácido gálico. Estes compostos podem ser responsáveis por até 30\% do peso seco do extrato de chá verde (CHACKO et al., 2010).

A maioria dos polifenóis do chá verde são os flavonóides comumente conhecidos como catequinas. Um polifenol é uma estrutura que apresenta mais de um anel aromático contendo pelo menos um grupo hidroxila ligado em cada anel. Já o nome flavonóide é dado a um grande grupo de metabólitos secundários da classe dos polifenóis. A estrutura básica dos flavonoides é composta por três anéis fenólicos, o anel benzeno (A) que é condensado com o sexto membro do anel C, o qual é portador de um anel fenil benzeno na segunda posição, como um substituinte (AHERNE; O'BRIEN, 2002) (Figura 6). Os flavonóides são ainda subdivididos em classes conforme estrutura e nível de oxidação do anel C, sendo os principais 
grupos: antocianinas, flavanas, flavononas, flavonas, flavonóis e isoflavonóides. As catequinas e as epicatequinas estão presentes em diversos alimentos, enquanto os galatos e galatocatequinas estão presentes exclusivamente em chás, especialmente no chá verde. As catequinas são compostos incolores, hidrossolúveis, que contribuem para o amargor e a adstringência do chá verde (LIN; DELLA-FERA; BAILE, 2005) e são caracterizadas por possuírem anéis aromáticos e grupamentos hidroxila (DE PASCUAL-TERESA; MORENO; GARCIA-VIGUERA, 2010).

Figura 6 - Estrutura básica dos flavonoides.

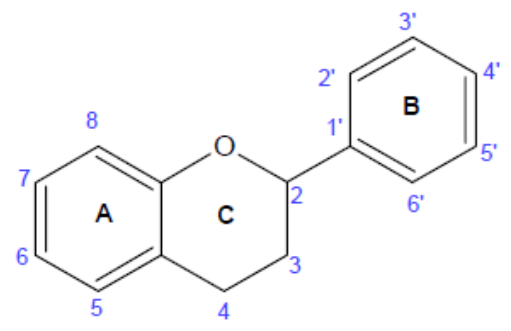

Fonte: Velayutham et al., Curr Med Chem. 2008

Diferentes preparações do chá verde contêm quantidades variáveis de polifenóis sendo a epigalocatequina 3-galato (EGCG) a mais abundante, mais estudada e, possivelmente a com maiores propriedades bioativas dentre os polifenóis encontrados no chá. Além da EGCG, que pode perfazer cerca de $50 \%$ a $80 \%$ dos polifenóis (BODE; DONG, 2009), outras catequinas incluem a epigalocatequina (EGC), a epicatequina galato (ECG) e a epicatequina (EC) (Figura 7).

Figura 7- Catequinas do chá verde

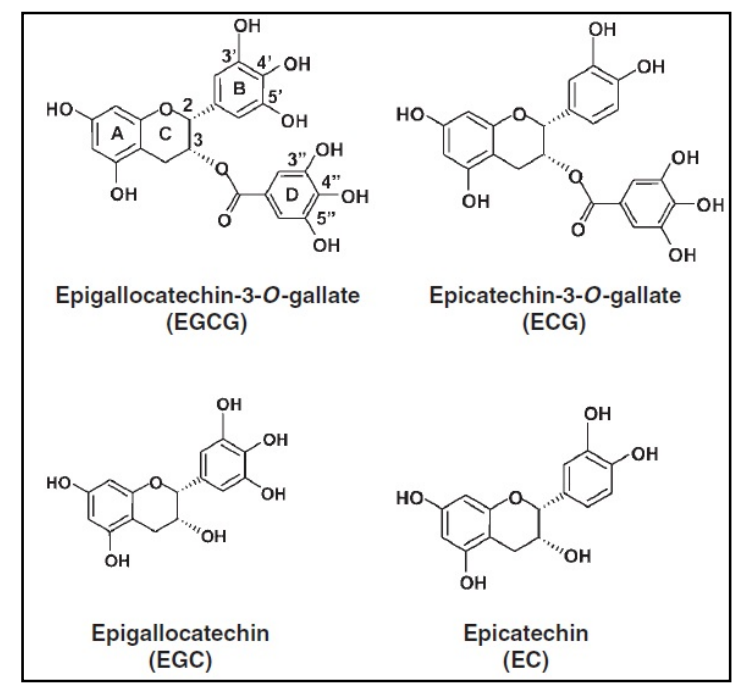

Fonte: Velayutham et al., Curr Med Chem. 2008 
Dentre os aspectos necessários para compreender a atividade das catequinas nos sistemas biológicos, é preciso conhecer sua forma de absorção, distribuição, metabolismo e eliminação pelo organismo. Os flavonoides sofrem extensivo metabolismo de primeira passagem. Na mucosa intestinal e no fígado, os flavonoides sofrem glucoronidação, metilação e sulfatação. Assim, após a ingestão de alimentos ricos em flavonoides, os metabólitos dos flavonoides são as formas encontradas no sistema circulatório que apresentam um pico entre 4-6h após a ingestão. Da mesma forma que drogas farmacêuticas e outros xenobióticos, a biotransformação afeta as propriedades físicas e químicas dos flavonoides, deixando-os mais solúveis em água e permitindo que sejam rapidamente excretados pela bile e urina (LOTITO et al., 2011).

Os estudos farmacocinéticos em humanos indicam que 0 pico de concentração plasmática após uma dose única de EGCG é maior que 1,0 $\mu \mathrm{M}$. Além disso, os níveis intracelulares de EGCG são muito menores do que as concentrações observadas no extracelular (TACHIBANA, 2011). Hoje se sabe que dentre as catequinas a EGCG é a mais rapidamente absorvida, distribui-se por todos os tecidos e possui um tempo de meia vida maior na corrente sanguínea. Quando administrada isoladamente, apresenta meia vida menor do que associada com outros compostos do extrato de chá verde. Esta propriedade está relacionada com a sua complexação, competição, metabolização e a interação com os demais compostos do extrato do chá verde (CHEN et al., 1997).

Observações recentes produziram resultados que afastaram muitos mitos e também confirmaram alguns benefícios importantes para a saúde em relação ao consumo regular do chá demonstrando que o chá tem propriedades funcionais e que, quando incluído na alimentação diária, pode trazer benefícios fisiológicos específicos, devido aos seus componentes (BODE; DONG, 2009). O consumo de chá verde apresenta correlação inversa entre obesidade generalizada, obesidade abdominal, morbidade e mortalidade cardiovascular e risco de câncer (LIN; DELLAFERA; BAILE, 2005).

As catequinas atuam nos processos inflamatórios prevenindo a inflamação vascular que desempenha um papel crítico na progressão de lesões ateroscleróticas (MODERNO; CARVALHO; SILVA, 2009). A atividade anti-inflamatória pode ser devido à supressão da adesão de leucócitos ao endotélio e posterior transmigração, inibição do fator de transcrição NFאB mediada por citocinas e moléculas de adesão, 
tanto em células endoteliais quanto em células inflamatórias (BABU; LIU, 2008). As catequinas também inibem a proliferação de células musculares lisas vasculares, interferindo com fatores de crescimento vascular das células envolvidas na aterogênese. Além disso, as catequinas podem suprimir a adesão plaquetária, inibindo assim a trombogênese. A EGCG apresenta ação anti-inflamatória capaz de inibir, in vitro, a ativação do fator de transcrição NFאB ao mesmo tempo em que inibe a degradação do $I_{\kappa} B-\alpha$ induzida pela ativação celular mediada pelo TNF- $\alpha$. O mecanismo de ação anti-inflamatório da EGCG parece também estar associado à diminuição da atividade da proteína IKK, envolvida na fosforilação do IKB- $\alpha$ (RAHMAN; BISWAS; KIRKHAM, 2006). Tomados em conjunto, podemos dizer que as catequinas podem prevenir as doenças cardiovasculares.

Durante a última década, a conhecimento que o consumo de chá verde trás benefícios a saúde tem recebido uma significativa atenção científica, particularmente, nas áreas de doenças cardiovasculares e oncologia. Devido a pandemia de obesidade, os efeitos antiobesidade do chá verde estão sendo investigados em estudos celulares, em animais e em humanos. Nestes modelos as catequinas reduzem a diferenciação e a proliferação de adipócitos, a lipogênese, a quantidade de tecido adiposo, o peso corporal, a absorção de gordura, os níveis plasmáticos de triglicerídeos, ácidos graxos livres, colesterol, glicose, insulina e leptina, assim como aumentam a beta-oxidação e a termogênese (LEE; BAE; YOON, 2013; LIN; LIN-SHIAU, 2006; YANG et al., 2012) 


\section{JUSTIFICATIVA}

As tendências de transição nutricional ocorridas neste século, em diferentes países no mundo, convergem para uma dieta rica em gorduras saturadas, açúcares e alimentos refinados, com baixo teor de carboidratos complexos e fibras, conhecida como dieta ocidental. Essa transição nutricional juntamente com o sedentarismo, características do processo de modernização, contribuíram para a incidência da obesidade na população mundial. Indivíduos obesos apresentam alterações metabólicas que podem afetar a função imune (STALLONE, 1994). Além dos fatores metabólicos envolvidos, os fatores nutricionais e endócrinos parecem influenciar a função imunológica. Há evidências de que o consumo excessivo de nutrientes altera várias funções relacionadas aos mecanismos de defesa imunológica (CHANDRA; KUTTY, 1980). Por exemplo, durante o curso de uma infecção a capacidade do sistema imune para desviar energia para ele próprio em resposta a agentes patogênicos é essencial para a resolução da ameaça. Assim, tanto as necessidades metabólicas do organismo quanto a de energia necessária às células imunes devem ser adequadamente coordenadas.

Diversos estudos epidemiológicos sugerem que os potenciais benefícios dos alimentos funcionais seriam através da redução do risco de desenvolvimento das doenças crônicas não transmissíveis (DCNT) tais como o câncer, doenças cardiovasculares, distúrbios metabólicos, doenças neurodegenerativas, enfermidades inflamatórias e obesidade. Na área da pesquisa com alimentos funcionais, a planta Camellia sinensis tem sido amplamente investigada devido ao seu conteúdo de flavonóides, representado pelas catequinas, que lhe confere inúmeras propriedades terapêuticas. Os flavonóides podem auxiliar na prevenção de DCNT, quando ingeridos de forma regular através da dieta, devido aos seus efeitos antioxidantes, anticarcinogênicos, anti-inflamatórios, antiaterogênicos, hipoglicemiantes, além da sua atividade antibacteriana e antiviral, as quais se refletem diretamente na prevenção e tratamento de várias doenças, principalmente as cardiovasculares. No entanto, as concentrações utilizadas in vitro são muitas vezes superiores às encontradas em animais ou no plasma humano, e então evidências in vivo são necessárias para demonstrar qualquer efeito protetor das catequinas. 
Nenhum dos estudos já realizados avaliou os efeitos da suplementação crônica com extrato de chá verde em animais obesos induzidos por dieta hipercalórica, avaliando parâmetros bioquímicos e funcionais de linfócitos, a fim de traçar um perfil dessas células em resposta ao tratamento com o chá verde na ausência e presença da obesidade. Assim, propomos que a suplementação crônica com o extrato de chá verde em animais obesos poderia ser capaz de modular funções importantes das células imunes, como os linfócitos, sendo capaz de melhorar as defesas antioxidantes, o estado redox, controlar a ativação de vias próinflamatórias nessas células desencadeadas pela condição de obesidade, além de promover um controle na proliferação celular e uma ativação eficiente dos linfócitos com características anti-inflamatórias. 


\section{OBJETIVO}

Avaliar os efeitos da suplementação crônica com extrato de chá verde sobre alguns parâmetros indicadores de estresse oxidativo e da funcionalidade de linfócitos de ratos induzidos à obesidade pela ingestão de dieta hipercalórica. 


\section{ESTRATÉGIAS}

Avaliar a proliferação de linfócitos T (estimulados com concanavalina A) e B (estimulados com lipopolissacarídeo);

* Avaliar a liberação de citocinas pró-inflamatórias (TNF-a, IL-2, IL-6, IL-1ß e IFN-y) e anti-inflamatória (IL-10);

* Avaliar a liberação intracelular de cálcio;

* Avaliar a produção de espécies reativas de oxigênio com auxílio das sondas DCFH-DA e dihidroetidina (DHE);

- Avaliar a atividade das enzimas antioxidantes superóxido dismutase, catalase, glutationa peroxidase e glutationa redutase e a razão GSH/GSSG.

* Avaliar a atividade das enzimas metabólicas hexoquinase e G6PDH. 


\section{MATERIAIS E MÉTODOS}

\subsection{Animais}

Utilizamos nesse estudo ratos Wistar (Rattus norvegicus, var. albinus) machos com peso inicial médio de $180 \pm 10 \mathrm{~g}$ obtidos do biotério da Universidade Federal de São Paulo (UNIFESP). Os animais receberam água e ração padrão ad libitum durante as 4 semanas iniciais. Após este período, os animais receberam dieta hipercalórica sob regime pair feeding por 8 semanas. Os animais foram mantidos em sala com temperatura constante de $23 \pm 2{ }^{\circ} \mathrm{C}$, sob ciclo de iluminação de 12/12 horas. Após este período, os animais foram eutanasiados por decapitação entre 12:00 e 14:00 h, para a posterior realização dos experimentos. Para todos os parâmetros propostos, o número mínimo de ratos por grupo foi de 10 . O protocolo de experimentação para uso de animais foi aprovado pela comissão de ética da Universidade de São Paulo CEUA- ICB/USP (Protocolo nำ 160/2013).

\subsubsection{Grupos experimentais e tratamento com extrato de chá verde in vivo}

Os animais ( $\mathrm{n}=10$ por grupo) foram divididos em 4 grupos:

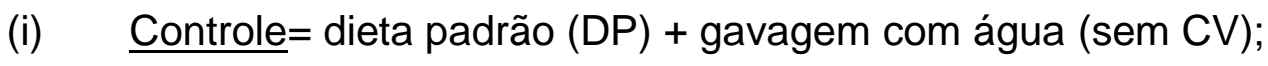

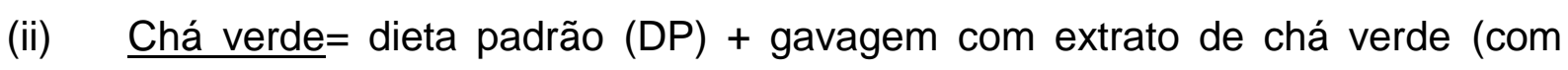
CV);

(iii) $\underline{\text { Obeso }}=$ dieta hipercalórica $(\mathrm{DH})+$ gavagem com água (sem $\mathrm{CV}$ );

(iv) Obeso + chá verde $=$ dieta hipercalórica $(\mathrm{DH})+$ gavagem com extrato de chá verde (com CV).

De acordo com LAMBERT et al. (2003) a administração intragástrica de EGCG em ratos na dose de $75 \mathrm{mg} / \mathrm{kg}$ resultou em uma Cmax de $128 \mathrm{mg} / \mathrm{L}$ de EGCG no plasma e uma meia-vida de 83 minutos. Em humanos, o consumo de EGCG na dose de $50 \mathrm{mg}$ (o equivamente a $0,7 \mathrm{mg} / \mathrm{kg}$ ) resultou em uma Cmax de $130 \mathrm{mg} / \mathrm{L}$ de EGCG no plasma e uma meia-vida de 112 minutos (ULLMANN et al., 2003). Estes resultados indicam que em roedores deve-se administrar por via oral, cerca de $100 \mathrm{a}$ 600 vezes mais EGCG (dependendo do modo de administração, se por sonda gástrica ou misturada na dieta) para se alcançar as concentrações plasmáticas semelhantes àquelas encontrados em humanos. 
Neste estudo administramos $500 \mathrm{mg} / \mathrm{Kg}$ de peso corporal de extrato de chá verde (CHENGELIS et al., 2008). O extrato de chá verde foi adquirido comercialmente da empresa Tovani- Benzaquen, São Paulo, SP. De acordo com as especificações apresentadas pela empresa obtidas por HPLC, as concentrações de polifenóis e catequinas presentes no extrato, representam cerca de 38\% (ISO 14502 -1:2005) e 24\% (ISO 14502 - 2:2005), respectivamente. Já o teor de cafeína presente no extrato representa foi de $4.5-7.5 \%$ do peso seco. O extrato foi pesado diariamente de acordo com os pesos corporais dos animais, e então solubilizado em água a $70{ }^{\circ} \mathrm{C}$ para posteriormente ser administrado de forma intragástrica aos animais.

A concentração de catequinas na infusão de uma preparação de chá verde varia de acordo com a preparação do chá, mas de forma geral o chá verde preparado em uma proporção de 1 grama de folhas para $100 \mathrm{~mL}$ de água, por 3 minutos de fervura, contém cerca de $35-45 \mathrm{mg} / 100 \mathrm{~mL}$ de catequinas e $6 \mathrm{mg} / 100$ mL de cafeína, dentre outros constituintes (KOO; CHO, 2004). Segundo Hasler, uma xícara de $240 \mathrm{~mL}$ de chá verde contém aproximadamente 200 mg de EGCG, o maior constituinte polifenólico do chá verde (HASLER, 2002).

Nosso estudo seguiu o design experimental proposto abaixo (Quadro 1). Os animais receberam suplementação, uma vez ao dia, de $2^{\underline{a}}$ a 6 $6^{\text {a }}$ feira (entre 17 e $18 \mathrm{~h}$ ) com extrato aquoso de chá verde (grupos chá e obeso+chá), enquanto que os grupos controle e obeso receberam gavagem intragástrica de água (mesmo volume de líquido oferecido aos animais que receberam o extrato de chá verde). O período total de suplementação com extrato de chá verde foi de 66 dias. Decorrido o período inicial de 22 dias de gavagem com chá verde, os animais receberam uma dieta hipercalórica durante 8 semanas. Neste período os animais foram suplementados com extrato de chá verde e a dieta hipercalórica. Durante o período de suplementação, os ratos foram pesados semanalmente para avaliação do ganho de peso. Além da pesagem semanal, avaliamos diariamente a ingestão da dieta pelos animais. Decorridos os 66 dias de suplementação os animais foram eutanasiados por decapitação e os linfonodos mesentéricos foram coletados.

O modelo de indução de obesidade utilizada no estudo se assemelha a grande parte da obesidade humana. É o modelo de obesidade exógena, onde é oferecido ao animal um maior aporte calórico, através de uma sobrecarga de carboidratos ou de gordura, isoladamente ou em associação. Esta dieta é 
denominada dieta "ocidentalizada" ou também chamada de dieta de cafeteria. Neste modelo experimental, acrescenta-se, ou associa-se à ração padrão substâncias altamente calóricas como bacon ou banha, castanhas, leite condensado, refrigerantes, chocolate, amendoim, guloseimas etc. Esta dieta produz um incremento de peso corporal total de aproximadamente $30-40 \%$ ao final de 12 semanas de estudo, além de produzir aumento significante na quantidade de gordura visceral e apresentar resistência à insulina e hiperleptinemia (BURNEIKO et al., 2006; CESARETTI; KOHLMANN JUNIOR, 2006; MACEDO et al., 2012; SCOARIS et al., 2010).

Neste estudo $100 \mathrm{~g}$ da dieta de cafeteria (hipercalórica) (Tabela 1) preparada e ofertada aos animais conteve $419 \mathrm{Kcal}$ dos quais: carboidratos - 46,63 g (47\%), proteínas - 13,86 g (15\%) e lipídeos - 16,49 g (38\%). Enquanto que, em $100 \mathrm{~g}$ de ração padrão encontra-se $288 \mathrm{Kcal}$ dos quais: carboidratos - $40 \mathrm{~g}$ (160 Kcal), proteínas - $23 \mathrm{~g}$ (92 Kcal) e lipídeos - $4 \mathrm{~g}$ (36 Kcal). Desse modo verifica-se um aumento de $46 \%$ das calorias totais em relação à dieta padrão, caracterizando-se assim como uma dieta hipercalórica.

Tabela 1 - Composição nutricional referente à $100 \mathrm{~g}$ da dieta de cafeteria.

\begin{tabular}{ccccc}
\hline & Carboidratos & Proteínas & Lipídeos & Kcal \\
\hline $\begin{array}{c}\text { Ração padrão } \\
\text { (37,5\%) }\end{array}$ & $15 \mathrm{~g}$ & $8,63 \mathrm{~g}$ & $1,5 \mathrm{~g}$ & $108 \mathrm{Kcal}$ \\
$\begin{array}{c}\text { Chocolate } \\
\text { (25\%) }\end{array}$ & $13,65 \mathrm{~g}$ & $1,73 \mathrm{~g}$ & $8,95 \mathrm{~g}$ & $142 \mathrm{Kcal}$ \\
$\begin{array}{c}\text { Leite condensado } \\
\text { (12,5\%) }\end{array}$ & $6,9 \mathrm{~g}$ & $0,95 \mathrm{~g}$ & $1,05 \mathrm{~g}$ & $40,85 \mathrm{Kcal}$ \\
$\begin{array}{c}\text { Amendoim } \\
\text { (12,5\%) }\end{array}$ & $1,98 \mathrm{~g}$ & $1,64 \mathrm{~g}$ & $3,1 \mathrm{~g}$ & $71,25 \mathrm{Kcal}$ \\
$\begin{array}{c}\text { Bolacha maisena } \\
\text { (12,5\%) }\end{array}$ & $9,1 \mathrm{~g}$ & $0,91 \mathrm{~g}$ & $1,89 \mathrm{~g}$ & $57 \mathrm{Kcal}$ \\
TOTAL CALÓRICO & $47 \%$ & $15 \%$ & $38 \%$ & $419 \mathrm{Kcal}$ \\
\hline
\end{tabular}

Dados referentes aos constituintes dietéticos presente na dieta preparada pelo nosso grupo (100 g da dieta). Para o preparo da dieta, os ingredientes foram triturados, misturados e peletizados para posterior oferta aos animais. 


\section{Quadro 1 - Design Experimental}

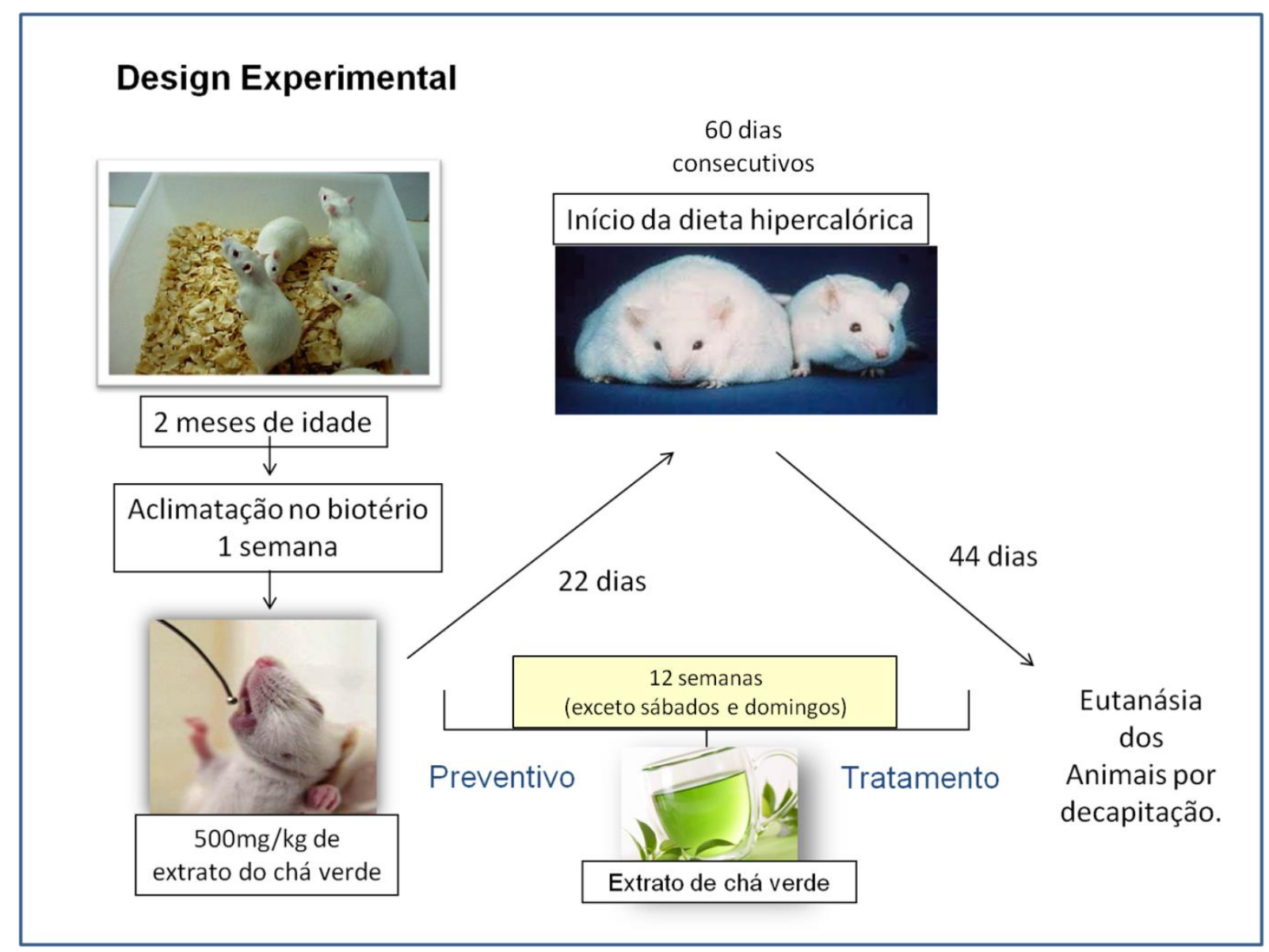

\subsubsection{Teste de Tolerância à Insulina (ITT)}

Uma semana antes da eutanásia dos animais foi realizado o ITT a fim de verificar se a dieta de cafeteria estava induzindo resistência periférica à insulina nos animais, o que caracterizaria a indução da obesidade. Após $6 \mathrm{~h}$ em jejum, os animais receberam uma dose de insulina via intraperitonial (1 U/kg peso corpóreo). Foi realizada uma pequena seç̧ão na extremidade distal da cauda do animal e a glicemia foi mensurada por meio de glicofita e glicosímetro (Biocheck TD-4225 / Bioeasy Diagnóstica Ltda / MG -Brasil). A coleta do material aconteceu no período da tarde por volta das $14 \mathrm{~h}$. Foi calculada a área total sob a curva da concentração plasmática de glicose entre os grupos e a constante de decaimento da glicose (KAMEl et al., 2006; WILASRUSMEE et al., 2002).

\subsubsection{Teste de Tolerância à Glicose (GTT)}


Uma semana antes da eutanásia dos animais realizamos o GTT a fim de verificar se a dieta de cafeteria estava induzindo a resistência periférica à insulina nos animais, o que caracterizaria a indução da obesidade. Para tanto administramos por via intraperitoneal $1,5 \mathrm{~g}$ glicose/Kg do peso corpóreo em solução salina a $20 \%$ de glicose. As amostras de sangue foram coletadas antes da administração de glicose (tempo 0) e a 5, 15, 30, 60 e 90 minutos após a aplicação (no período da tarde por volta das $14 \mathrm{~h}$ ). Foi realizada uma pequena secção na extremidade distal da cauda do animal e a glicemia foi mensurada por meio de glicofita e glicosímetro (Biocheck TD-4225 / Bioeasy Diagnóstica Ltda / MG -Brasil). Foi calculada a área total sob a curva (KAMEl et al., 2006) da concentração plasmática de glicose entre os grupos.

\subsubsection{Dosagem de leptina e adiponectina}

Após a eutanásia dos animais (que ocorreu entre 12 e 14 h) o sangue coletado foi centrifugado a $1200 \mathrm{rpm}, 10 \mathrm{~min}, 4{ }^{\circ} \mathrm{C}$ para a obtenção do plasma. Foi dosada a concentração de leptina e adiponectina plasmática por ELISA (R\&D Systems e Abcam, respectivamente) que utiliza um anticorpo específico para essas adipocinas de rato revestida sobre uma placa de 96 poços. Padrões e amostras foram pipetadas na placa ligando-se ao anticorpo. Após incubação e lavagem foi adicionado anticorpo biotinilado, os poços foram novamente lavados para retirada do anticorpo e foi pipetado estreptavidina conjugada com HRP. Ocorreu mais uma lavagem e então foi adicionado o substrato TMB, e a mudança de cor de azul para amarelo, foi proporcional à quantidade das adipocinas nas amostras (avaliada por espectrofotometria a $450 \mathrm{~nm}$ ).

\subsubsection{Dosagem de ácidos graxos}

A dosagem de ácidos graxos livres foi realizado no plasma (obtido após centrifugação do sangue dos animais a $1200 \mathrm{rpm}, 10 \mathrm{~min}, 4^{\circ} \mathrm{C}$ ) pelo Kit de fluorescência para ácidos graxos livres (Cayman), que utiliza uma reação enzimática acoplada a uma peroxidase. A fluorescência foi mensurada com excitação entre 530-540 nm e emissão entre 585-595 nm. 
5.1.6 Avaliação das reservas de gordura epididimal, perirenal e subcutânea

Imediatamente após a autanasia dos animais, o tecido adiposo epididimal, perirenal e subcutâneo de cada animal foi retirado e pesado a fim de quantificarmos o tamanho dos depósitos de gorduras. Os valores obtidos foram expressos como peso em gramas de tecidos $/ 100 \mathrm{~g}$ de peso corporal.

\subsection{Obtenção de linfócitos dos linfonodos mesentéricos}

Após a eutanásia dos animais por decapitação os mesmos foram colocados sobre uma placa e então realizou-se um corte sagital, na região abdominal, e posteriormente a musculatura do abdômen foi aberta. Foram localizados e retirados os linfonodos mesentéricos, sendo em seguida separado o tecido ganglionar linfóide do tecido gorduroso. Para a obtenção dos linfócitos mesentéricos foi utilizado um sistema no qual os linfócitos foram comprimidos (maceração) sobre uma malha através de movimentos circulares realizados com a ajuda de um êmbolo de seringa, obtendo-se linfócitos íntegros e isolados. Acrescentou-se $10 \mathrm{ml}$ de PBS gelado com o auxilio de uma gaze esterilizada, o líquido foi filtrado no tubo de plástico. O líquido já no tubo de plástico foi centrifugado por 10 minuto a $1200 \mathrm{rpm}$. O sobrenadante foi descartado e o pellet foi ressuspendido em meio RPMI 1640. Foram retirados $10 \mu \mathrm{L}$ da amostra para determinação da viabilidade celular por exclusão deTriplan Blue (Sigma, St. Louis, MO, USA) em câmara de Neubauer.

\subsubsection{Cultura de linfócitos}

Linfócitos foram cultivados em placas de 24 ou 96 poços contendo meio de cultura RPMI-1640 com 10\% de soro fetal bovino e antibióticos (penicilina $10.000 \mathrm{U}$ e estreptomicina $10 \mathrm{mg} / \mathrm{L}$ de meio). As células $\left(2,5 \times 10^{6} / \mathrm{mL}\right)$ foram cultivadas a $37^{\circ} \mathrm{C}$ e atmosfera de $95 \%$ de ar e $5 \%$ de $\mathrm{CO}_{2}$ por $48 \mathrm{~h}$ para os ensaios de proliferação celular ou $24 \mathrm{~h}$ para a produção de citocinas. As células frescas foram utilizadas para avaliação da produção de EROs e a liberação de cálcio.

\subsubsection{Determinação da capacidade proliferativa de linfócitos}


Neste trabalho utilizamos o kit BrdU para avaliar a capacidade proliferativa dos linfócitos. Este é um imunoensaio colorimétrico para a quantificação da proliferação celular baseada na mensuração da incorporação de BrdU durante a síntese de DNA. O kit de proliferação celular BrdU detecta 5-bromo-2'-deoxiuridina (BrdU) incorporado ao DNA celular durante a proliferação celular usando um anticorpo anti-BrdU-POD, que é conjugado a uma peroxidase. O BrdU é um análogo da base pirimídica timidina que é incorporado no lugar da timidina dentro da nova fita sintetizada de DNA das células proliferativas. $3 \times 10^{5}$ células foram cultivadas na presença dos estímulos ConA (20 $\mu$ l de uma solução a $20 \mu \mathrm{g} / \mathrm{mL})$ ou LPS $(20 \mu \mathrm{l}$ de uma solução a $100 \mu \mathrm{g} / \mathrm{ml}$ ) em um volume final de $100 \mu \mathrm{l} /$ poço, para a proliferação de linfócitos T e B, respectivamente, durante 48 horas a $37{ }^{\circ} \mathrm{C}$, atmosfera de $95 \%$ de ar e $5 \%$ de $\mathrm{CO}_{2}$. Após esse período foi adicionado $100 \mu \mathrm{l} /$ poço de uma solução de BrdU labeling $(100 \mu \mathrm{M})$ e as células foram incubadas por 3 horas a $37^{\circ} \mathrm{C}$, atmosfera de $95 \%$ de ar e $5 \%$ de $\mathrm{CO}_{2}$. A microplaca foi então centrifugada a $300 \mathrm{~g} \times$ por 10 minutos e o meio de cultura foi removido por inversão da placa ou aspiração por pipeta. Após remoção do meio, as células foram fixadas e o DNA foi desnaturado com a adição de $200 \mu$ de uma solução de fixação/desnaturação presente no kit e então incubadas por 30 minutos a temperatura ambiente. Em seguida a solução de fixação/desnaturação foi removida por inversão da placa e então foi adicionado 100 $\mu \mathrm{l} /$ poço de uma solução 1:200 de anticorpo anti-BrdU-POD, para detectar a incorporação do BrdU (a desnaturação do DNA é necessária para melhorar o acesso do BrdU incorporado à detecção pelo anticorpo), e as células foram incubadas por 90 minutos a temperatura ambiente. O anticorpo anti-BrdU foi então removido por inversão da placa e esta foi lavada com $200 \mu \mathrm{l}$ de PBS. Uma solução substrato foi adicionada para o desenvolvimento de coloração no ensaio que posteriormente foi avaliado por absorbância em espectrofotometria a $450 \mathrm{~nm}$ (tendo como referência $690 \mathrm{~nm})$.

\subsubsection{Ensaio de interleucinas pró- e anti-inflamatórias pelo método de ELISA}

A produção de citocinas foi avaliada por imunoensaio quantitativo através de kits DuoSet da R\&D System (Minneapolis, MN, USA). O princípio básico do teste é a imobilização de um dos reagentes em uma fase sólida, enquanto outro reagente pode ser ligado a uma enzima, com preservação tanto da atividade enzimática como 
da imunológica do antígeno. A fase sólida, ou seja, o anticorpo de captura utilizado foi anti-IL-2, IFN- $\gamma$, TNF- $\alpha$, IL-6, IL-10 e IL-1 $1 \beta$. Para este ensaio os linfócitos $\left(5 \times 10^{5}\right)$ foram previamente tratados com estímulos específicos como Con A $(10 \mu \mathrm{g} / \mathrm{ml})$, LPS $(80 \mu \mathrm{g} / \mathrm{ml})$, PMA (100 $\mathrm{ng} / \mathrm{ml})$ e ionomicina $(500 \mathrm{ng} / \mathrm{ml})$ em um tempo adequado para cada citocina analisada. Após a cultura as células foram coletadas, centrifugadas e 0 sobrenadante foi utilizado para a avaliação da presença das interleucinas pró- e antiinflamatórias. O estímulo utilizado e o tempo de cultura para cada citocina avaliada foi determinado através de diversos testes e ensaios realizados pelo nosso grupo de pesquisa (BOLIN et al., 2012). Assim definimos que para a avaliação da produção de IL-2 as células deveriam ser estimuladas com Con A por $24 \mathrm{~h}$. Para IL-6, IL-1ß e TNF- $\alpha$ o melhor estímulo observado foi o LPS por $18 \mathrm{~h}$. Para a produção de IFN- $\gamma$ as células foram estimuladas com PMA e ionomicina por $24 \mathrm{~h}$ e a produção de IL-10 foi determinada com os estímulos de LPS e Con A por $24 \mathrm{~h}$. Os resultados foram apresentados como quantidade em $\mathrm{pg} / \mathrm{mL}$ de interleucinas produzidas/ $5 \times 10^{5}$ células.

\subsubsection{Avaliação da concentração intracelular de cálcio}

Mudanças na concentração intracelular de cálcio foram monitoradas fluorimetricamente usando a sonda cálcio-sensível fura 2-AM como descrito previamente (OTTON et al., 2007). O período de marcação da sonda fura 2- AM (5 $\mu \mathrm{M})$ foi de $1 \mathrm{~h}$ para $1 \times 10^{6}$ células em solução Tyrode em estufa a $37^{\circ} \mathrm{C}$ no escuro.

O monitoramento da mudança da concentração intracelular de cálcio $\left[\mathrm{Ca}^{2+}\right]_{\mathrm{i}}$ foi realizado por 5 minutos em espectrofluorímetro e a fluorescência do fura 2-AM foi avaliada em alíquotas de $300 \mu$ ajustando-se os comprimentos de excitação a $340 \mathrm{e}$ $380 \mathrm{~nm}$ e emissão a $510 \mathrm{~nm}$. Uma curva de calibração foi executada no final de cada experimento. A transformação do sinal fluorescente de cálcio foi executada pela calibração com o ionóforo ionomicina (100 $\mu \mathrm{M}$ concentração máxima) seguida pela adição do quelante de cálcio EGTA (60 $\mu \mathrm{M}$ concentração mínima) de acordo com a equação de Grynkiewicz, usando a constante da dissociação de 224 nm (de acordo com o catálogo molecular Probes). Os resultados deste experimento foram expressos como quantidade total de cálcio durante 5 minutos pela análise da área sobre a curva (KAMEl et al., 2006). 


\subsection{Produção de EROs avaliado pelo ensaio de DCFH-DA}

A sonda DCFH-DA é clivada irreversivelmente por esterases intracelulares e então oxidada a 2,7-dicloro-fluoresceína (DCF) por EROs. Para este ensaio $5 \times 10^{5}$ células foram incubadas com DCFH-DA $(5 \mu \mathrm{M})$ em meio de cultura RPMI 1640 por 30 minutos. Após esse período as células foram estimuladas ou não com $5 \mu \mathrm{l}$ PMA (forbol meristato acetato) a partir de uma solução inicial de $6,5 \mu \mathrm{M}$, durante $3 \mathrm{~h}$ a 37 ${ }^{\circ} \mathrm{C}$. Após esse período, as células foram centrifugadas e ressuspendidas em $300 \mu \mathrm{l}$ de tampão Tyrode e a fluorescência foi monitorada em espectrofluorímetro Tecan (Salzburg, Áustria) com excitação de $485 \mathrm{~nm}$ e emissão a $530 \mathrm{~nm}$. Os resultados desse experimento foram expressos como unidade relativa de fluorescência.

\subsubsection{Produção de EROs usando a sonda dihidroetidina (DHE)}

A sonda fluorescente DHE foi utilizada para avaliação do conteúdo intracelular de ânion superóxido por leitor de fluorescência. A DHE é uma sonda lipofílica que se difunde prontamente através das membranas das células. Uma vez dentro da célula, ela é oxidada rapidamente a etídio (um composto fluorescente vermelho) pelo ânion superóxido. O etídio é aprisionado no núcleo intercalando-se ao DNA, conduzindo a um aumento da fluorescência na célula. Para este ensaio $5 \times 10^{5}$ células foram incubadas com dihidroetidina ( $5 \mu \mathrm{M})$ em tampão Tyrode (300 $\mu$ ) por 15 minutos, a temperatura ambiente, no escuro. Após a marcação, as células foram centrifugadas e ressuspendidas em $300 \mu \mathrm{l}$ de Tyrode, para então iniciar-se um período de incubação de 30 minutos no escuro a temperatura ambiente na presença e na ausência de $5 \mu \mathrm{l}$ de PMA $(6,5 \mu \mathrm{M})$ como ativador do burst respiratório de leucócitos. Após esta incubação a fluorescência foi monitorada em espectrofluorímetro Tecan (Salzburg, Áustria), com excitação a $396 \mathrm{~nm}$ e emissão a $590 \mathrm{~nm}$. Os resultados deste experimento foram expressos como unidade relativa de fluorescência.

5.4 Procedimentos para a avaliação da atividade das enzimas antioxidantes e metabólicas

Foram utilizados $5 \times 10^{6}$ células, as quais sofreram ruptura por sonicação em tampão fosfato, e em seguida foram centrifugadas a $10.000 \times \mathrm{g}$ por 10 minutos a 4 ${ }^{\circ} \mathrm{C}$. Após a sonicação e centrifugação, o pellet foi desprezado e o sobrenadante foi 
retirado e passado para outro tubo para posterior realização dos ensaios enzimáticos.

\subsubsection{Atividade da Superóxido dismutase}

A análise da atividade da enzima superóxido dismutase (SOD), seguiu a metodologia descrita por EWING e JANERO (1995). Para tal, a redução do radical superóxido $\left(\mathrm{O}_{2}^{-}\right)$pelo nitroblue tetrazolium (NBT) - produzidos a partir da fenazina metassulfato (PMS) - deve seguir uma cinética de primeira ordem linear durante todo o intervalo de tempo (3 min). As soluções foram preparadas e os sistemas de reação foram compostos por: em uma placa de 96 poços, foi adicionado $300 \mu \mathrm{l}$ de tampão fosfato 50 mM pH 7.4 contendo EDTA 0.1 mM, NBT $320 \mu \mathrm{M}$ e NADH $98 \mu \mathrm{M}$, aos quais foram adicionados $25 \mu \mathrm{l}$ de amostra e $25 \mu \mathrm{l}$ de um solução de fenazina metasulfato (PMS) a 2 nM (disparador). A cinética da reação de formação de radicais superóxido e redução do NBT a formazan foi acompanhada a $560 \mathrm{~nm}$ por 3 min, com leituras a cada 25 segundos (25 ํㅡ) usando um leitor de microplaca (Tecan, Salzburg, Austria). Para a dosagem de SOD Mn, foi adicionado ao sistema de reação $5 \mu \mathrm{M}$ cianeto de sódio $(\mathrm{NaCN})$, um inibidor da SOD/CuZn. O sistema branco - redução máxima do NBT pela quantidade de $\mathrm{O}_{2}^{-}$produzida pelo PMS adicionado - foi realizado pela substituição da amostra por tampão fosfato $50 \mathrm{mM}$ pH 7,4. Para a avaliação da atividade da SOD/CuZn, subtraímos os valores encontrados da SOD total pelos valores obtidos no ensaio da SOD Mn.

\subsubsection{Atividade da Catalase}

A dosagem de catalase foi realizada através do monitoramento da decomposição do $\mathrm{H}_{2} \mathrm{O}_{2}$ durante 2 minutos usando um leitor de microplaca (Tecan, Salzburg, Austria) a $240 \mathrm{~nm}$ em placa de 96 poços. Para o sistema de reação utilizamos $25 \mu \mathrm{l}$ de tampão fosfato $0,1 \mathrm{M}, 25 \mu \mathrm{l}$ de amostra e $200 \mu \mathrm{l}$ de $\mathrm{H}_{2} \mathrm{O}_{2}$ a 10 $\mathrm{mM}$ (disparador).

\subsubsection{Dosagem da atividade de glutationa peroxidase}

Este ensaio baseia-se na redução de hidroperóxidos pela glutationa. Neste método, a atividade da GPx foi monitorada com o uso de glutationa oxidada 
acoplada à reação com a enzima glutationa redutase, processo que consome NADPH. Em uma placa de 96 poços foi adicionado $30 \mu \mathrm{l}$ de amostra, $103 \mu \mathrm{l}$ de tampão fostato $0,2 \mathrm{M}, 37 \mu \mathrm{l}$ de azida sódica como inibidor de catalase $(2,5 \mathrm{mM}), 37$ $\mu \mathrm{l}$ de $\beta$ - NADPH (1,2 mM), $37 \mu$ de glutationa reduzida (em $10 \mathrm{mM}$ em ácido fosfórico a $5 \%$ ) e $37 \mu$ de glutationa redutase $(2,5 \mathrm{U} / \mathrm{mL})$. A reação foi disparada com a adição de 4,8 mM de terc-butil-hidroperóxido. A oxidação de NADPH foi registrada espectrofotometricamente em um leitor de microplaca a $340 \mathrm{~nm}$ por 3 minutos.

\subsubsection{Dosagem da atividade de glutationa redutase}

Este ensaio baseia-se na redução da glutationa oxidada para glutationa reduzida numa reação dependente de NADPH. Esta redução é essencial para a manutenção dos níveis intracelulares de glutationa reduzida. Em uma placa de 96 poços foi adicionado $30 \mu \mathrm{l}$ de amostra, $270 \mu \mathrm{l}$ de tampão fostato $0,2 \mathrm{M}$ contendo 6,3 mM de EDTA, $37 \mu \mathrm{l}$ de $\beta$ - NADPH (3,6 mM), $37 \mu \mathrm{l}$ de glutationa oxidada (em $10 \mathrm{mM}$ em tampão fosfato $0,2 \mathrm{M})$. A reação foi disparada com a adição de NADPH. A oxidação de NADPH foi registrada espectrofotometricamente em um leitor de microplaca a $340 \mathrm{~nm}$ por 3 minutos.

\subsubsection{Razão das glutationas}

A avaliação da relação GSH/GSSG seguiu a metodologia descrita por Rahman (RAHMAN; KODE; BISWAS, 2006). O protocolo para dosar glutationa envolve a reação da GSH com o sulfidril 5,5'-dithio-bis(2-ácido nitrobenzóico) (DTNB) para formar um composto amarelo 5'-thio-2-ácido nitrobenzóico (TNB) que é mensurado a $412 \mathrm{~nm}$ e adutos de glutationa oxidada (GS-TNB). O produto dissulfido (GS-TNB) é então reduzido pela glutationa redutase (GR) na presença de NADPH, reciclando GSH. Para este ensaio, foi utilizado um tampão de extração que continha $4 \mathrm{mM}$ de $\mathrm{KH}_{2} \mathrm{PO}_{4}, 20,5 \mathrm{mM}$ de $\mathrm{K}_{2} \mathrm{HPO}_{4}, 0,1 \mathrm{mM}$ de EDTA, ácido sulfosalicílico $(0,6 \%)$ e Triton X100 (0,1\%). Para a avaliação de GSH total utilizamos uma placa contendo 96 poços, na qual foram pipetados $20 \mu \mathrm{l}$ de amostra, $120 \mu \mathrm{l}$ da solução contendo 0,083 $\mu \mathrm{M}$ DTNB (sulfidril 5,5'-dithio-bis(2-ácido nitrobenzóico) + $33,3 \mu \mathrm{l}$ de glutationa redutase $(500 \mathrm{U} / \mathrm{ml})$ e $60 \mu \mathrm{l}$ de $\beta$-NADPH $(0,079 \mu \mathrm{M})$. Para a 
avaliação de glutationa oxidada (GSSG), o sobrenadante das células foram tratados com $2 \mu \mathrm{l}$ da solução de 2-vinilpiridina ( $20 \mu \mathrm{l}$ de vinilpiridina, $4 \mathrm{mM}\left(\mathrm{KH}_{2} \mathrm{PO}_{4}\right), 20,5$ $\mathrm{mM}\left(\mathrm{K}_{2} \mathrm{HPO}_{4}\right)$ e 0,1 mM de EDTA) durante $1 \mathrm{~h}$ e então seguida da neutralização com trietanolamina. Em uma placa de 96 poços foram adicionados $20 \mu \mathrm{l}$ da amostra tratada, $120 \mu \mathrm{l}$ da solução contendo 0,083 $\mu \mathrm{M}$ DTNB (sulfidril 5,5'-dithio-bis(2-ácido nitrobenzóico $)+33,3 \mu \mathrm{l}$ de glutationa redutase $(500 \mathrm{U} / \mathrm{ml})$ e $60 \mu \mathrm{l}$ de $\beta$-NADPH $(0,079 \mu \mathrm{M})$ - disparador. Os resultados estão expressos como razão entre GSH $(\mu \mathrm{M} /$ mg de proteína) e GSSG ( $\mu \mathrm{M} / \mathrm{mg}$ de proteína).

\subsubsection{Atividade da Hexoquinase}

A atividade máxima da hexoquinase (enzima que catalisa a fosforilação da glicose na primeira reação da via glicolítica) foi determinada segundo o método descrito por CRABTREE e NEWSHOLME (1972). O tampão de extração dessa enzima constituiu-se de Tris- $\mathrm{HCl}(50 \mathrm{mM}), \operatorname{EDTA}(1 \mathrm{mM}), \mathrm{MgCl}_{2}(2 \mathrm{mM}) \mathrm{e}$ mercaptoetanol $(30 \mathrm{mM}), \mathrm{pH} 7,5$. Para o ensaio foi utilizado um tampão contendo Tris- $\mathrm{HCl}(75 \mathrm{mM}), \mathrm{MgCl}_{2}(7,5 \mathrm{mM})$, EDTA $(0,8 \mathrm{mM}), \mathrm{KCl}(2,95 \mathrm{mM})$, mercaptoetanol (4 mM), NADP+ (0,4 mM), ATP ( 2,5 mM), glicose (1 mM), creatina-fosfato (10 mM),

creatina quinase $(1,8 \mathrm{U})$, glicose-6-fosfato desidrogenase (14 U) e Triton X-100 0,05\% (v/v). Em placa de 96 poços foram adicionados $284 \mu \mathrm{l}$ do tampão de ensaio, $17 \mu \mathrm{l}$ de amostra e $37 \mu \mathrm{l}$ de glicose (disparador). A atividade da enzima foi avaliada em um leitor de microplaca a $340 \mathrm{~nm}$ por 5 minutos. Os resultados foram expressos em nmol/ $\mathrm{min} /$ proteína.

\subsubsection{Glicose-6-fosfato desidrogenase (G6PDH)}

$\mathrm{Na}$ avaliação da atividade da glicose-6-fosfato-desidrogenase (enzima que catalisa a conversão de glicose-6-fosfato em 6-fosfoglucona- $\delta$-lactona na presença de NADP), as células $5 \times 10^{6}$ foram coletadas, centrifugadas e ao pellet foi adicionado tampão de extração constituído de Tris- $\mathrm{HCl}(50 \mathrm{mM})$, EDTA (1 mM) em pH 8,0. O tampão de ensaio que foi utilizado conteve Tris- $\mathrm{HCl}$ (86 mM), $\mathrm{MgCl}_{2}$ (6,9 mM), $\mathrm{NADP}+(0,4 \mathrm{mM})$, Triton X-100 0,05\% (v/v) e glicose-6-fosfato (1,2 mM) como disparador, em pH 7,6. Em placa de 96 poços foi adicionado $267 \mu$ de tampão de ensaio, $30 \mu \mathrm{l}$ de amostra e $37 \mu \mathrm{l}$ de disparador. O início da reação ocorreu pela 
adição de glicose-6-fosfato (disparador) ao meio e a atividade da enzima foi mensurada em um leitor de microplaca a $340 \mathrm{~nm}$ por $5 \mathrm{~min}$. Os resultados foram expressos em $\mathrm{nmol} / \mathrm{min} / \mathrm{mg}$ de proteína.

5.5 Determinação das proteínas totais nos homogenatos

A determinação do conteúdo total de proteínas das amostras foi realizada segundo o método de BRADFORD (1976), usando-se albumina bovina sérica como padrão e a leitura da absorbância a $595 \mathrm{~nm}$ em espectrofotômetro.

\subsection{Análise Estatística}

A análise estatística foi realizada usando o programa GraphPad Prism versão 5.02. Os resultados foram expressos como média \pm erro padrão da média (EPM) e analisados estatisticamente pelo teste de Two Way ANOVA (pós - teste Bonferroni), adotando-se como limite mínimo de significância $p<0.05$. 


\section{RESULTADOS}

\subsection{Caracterização da obesidade}

A resistência à insulina é um estado comum associado à obesidade, envelhecimento, hábito de vida sedentária e predisposição genética. O desequilíbrio na regulação do metabolismo de carboidratos e lipídeos decorrente da resistência à insulina gera um ciclo vicioso com prejuízos na sensibilidade tecidual à insulina. As células beta-pancreáticas inicialmente compensam o estado de resistência à insulina, aumentando a secreção desse hormônio. Com o avançar da resistência, essas células falham em responder adequadamente à presença de glicose e conduzem o sistema ao estado de intolerância à glicose (SHULMAN, 2000; TANIGUCHI et al., 2006).

Dessa forma, para caracterizarmos a obesidade induzida pela dieta de cafeteria avaliamos alguns parâmetros como os testes de ITT e o cálculo do Kitt, que avaliam a tolerância à insulina e o teste de GTT que avalia a tolerância à glicose. Como podemos observar na Figura 8A (ITT- área sobre a curva) os animais obesos (DH sem CV) apresentaram um aumento na glicemia durante as avaliações realizadas nos tempos $0,5,15,30,60,90$ e 120 minutos comparado ao grupo controle (DP sem $\mathrm{CV}$ ), indicando uma resistência periférica à insulina. Já o tratamento com chá verde na condição de obesidade (DH com CV) foi capaz de diminuir essa resistência em relação ao grupo obeso. Esse mesmo fenômeno está apresentado na Figura 8B que avaliou a taxa de decaimento da glicose na corrente sanguínea (WILASRUSMEE et al.), na qual o grupo obeso (DH sem CV) apresentou uma diminuição da constante de decaimento de glicose da corrente sanguínea, indicando uma resistência à insulina em relação ao grupo controle (DP sem CV).

$\mathrm{Na}$ Figura $8 \mathrm{C}$ nos resultados do GTT observamos que o grupo obeso (DH sem CV) apresentou um aumento na glicemia em relação ao controle e aos demais grupos, conferindo assim intolerância à glicose na condição de obesidade. $O$ tratamento com chá verde nesta condição (DH com CV) foi capaz de restaurar a tolerância, apresentando valores similares ao grupo controle. 
Figura 8 - Teste de tolerância à insulina (A), Cálculo da constante de decaimento da glicose na corrente sanguínea $(B)$ e Teste de tolerância à glicose $(C)$.

\section{A}

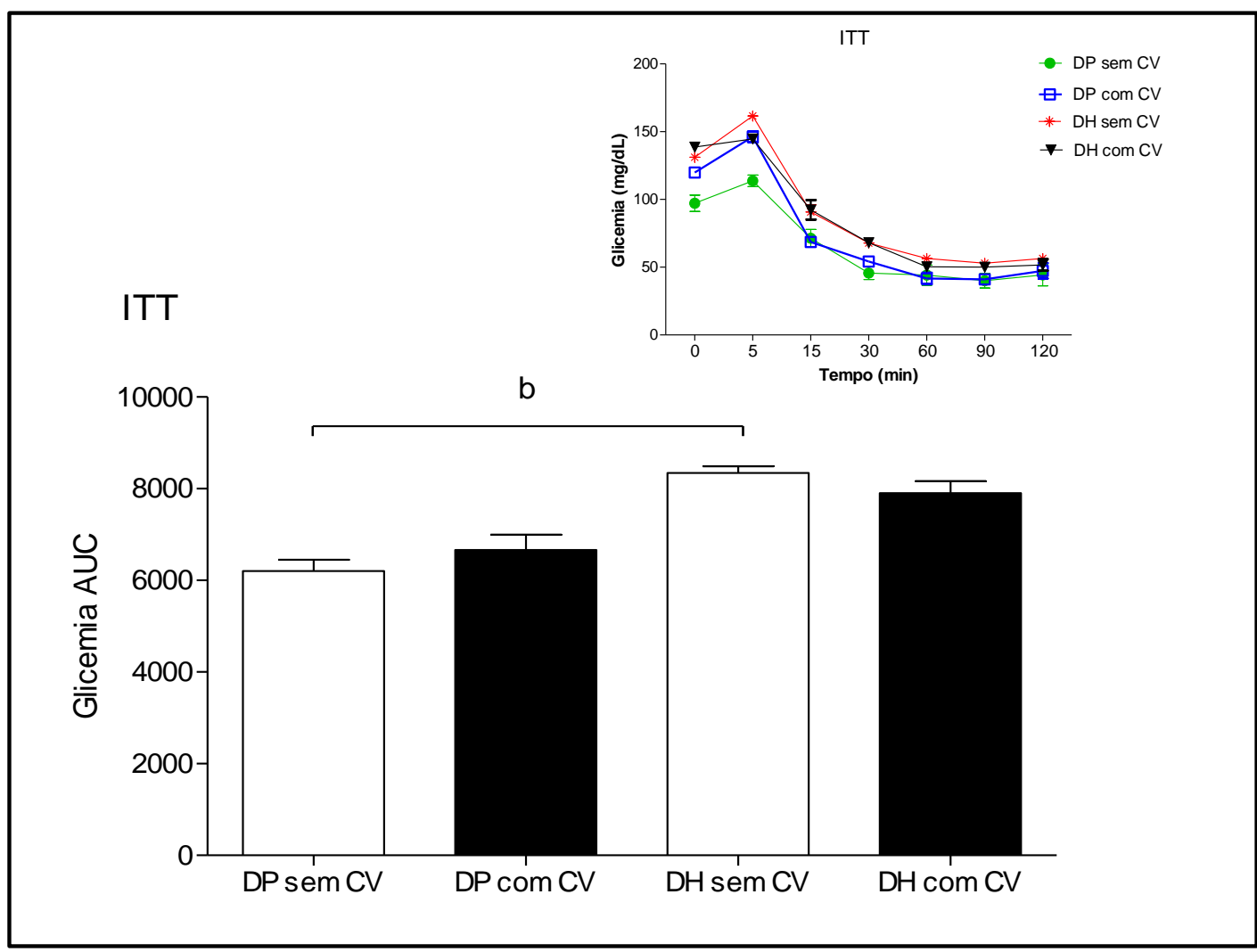

$B$

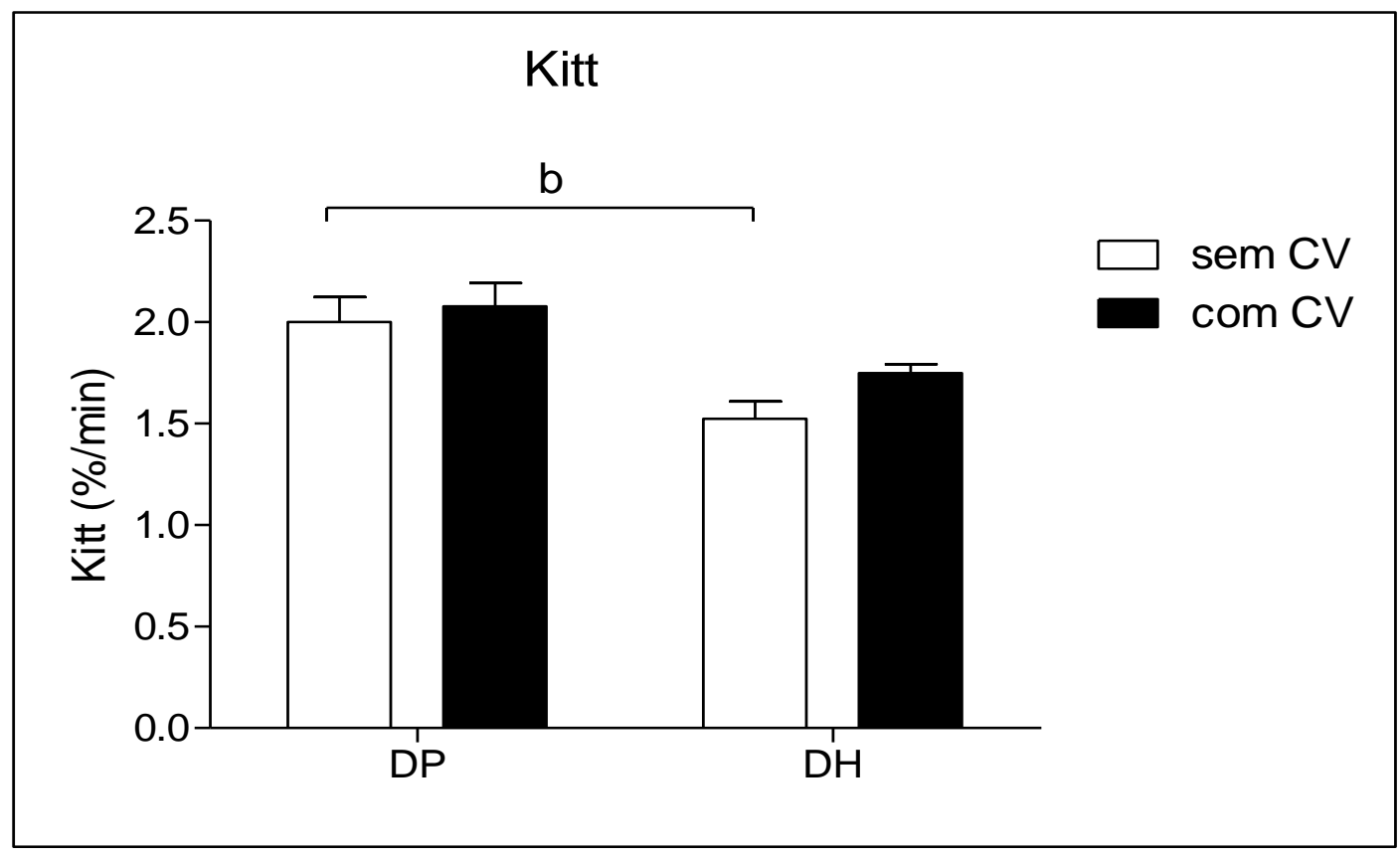


C

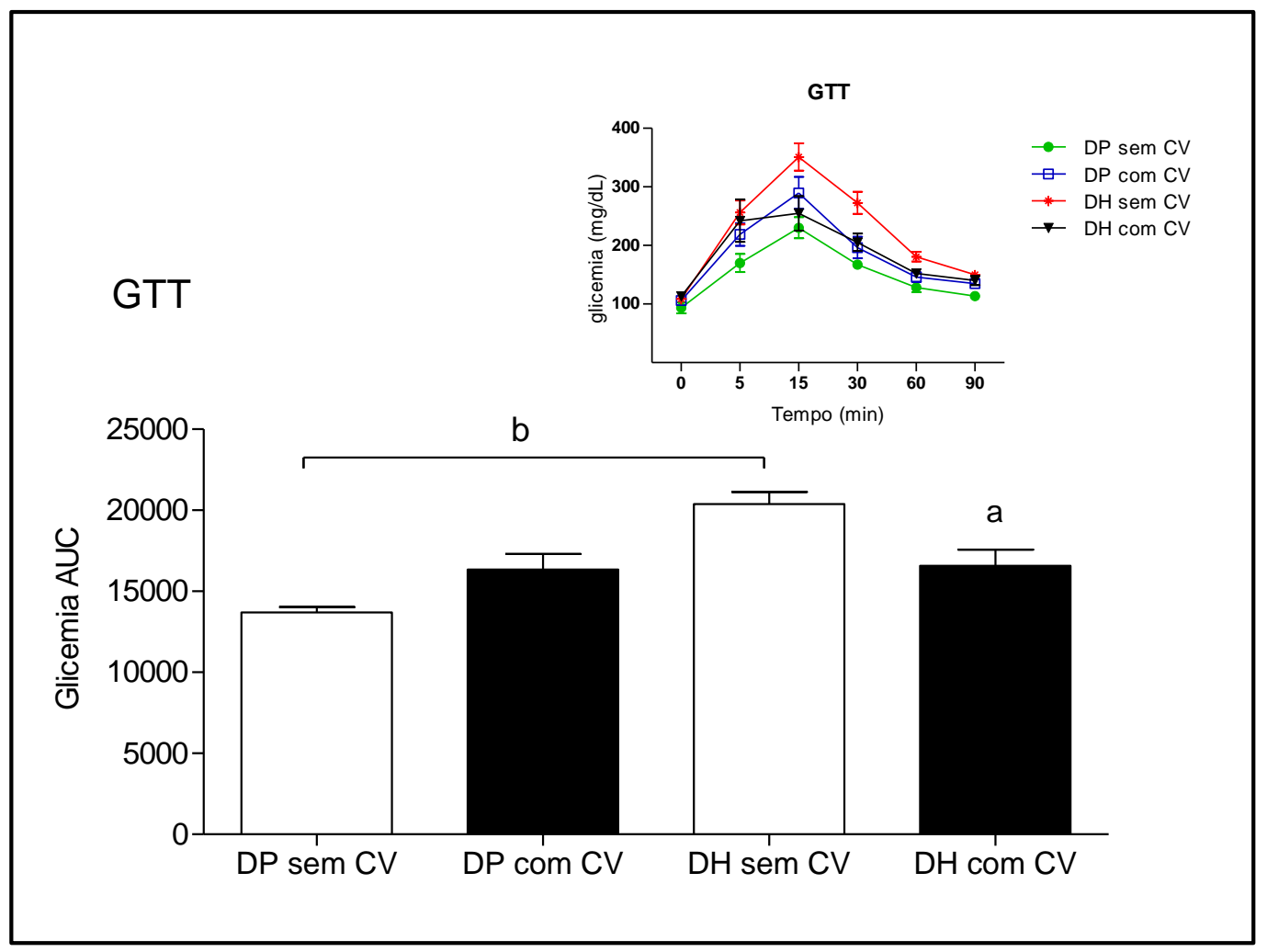

Teste de tolerância à insulina $(\mathrm{A})$, Constante de decaimento da glicose $(\mathrm{B})$ e Teste de tolerância à glicose (C). As avaliações da glicemia foram realizadas nos tempos de $0,5,15,30,60$ e 90 minutos após a dose intraperitoneal de insulina ou glicose. $\mathrm{DH}=$ dieta hipercalórica, $\mathrm{DP}=$ dieta padrão e $\mathrm{CV}=$ chá verde. Os resultados estão apresentados como média \pm EPM de pelo menos 10 animais. Para a análise estatística foi utilizado two-way ANOVA com pós-teste de Bonferroni, com $p<0,05$. $a=$ diferente significativamente em relação aos animais sem chá verde tratados com a mesma dieta (DP sem CV ou DH sem CV), b=diferente significativamente do grupo controle (DP sem CV).

Além dos parâmetros apresentados anteriormente outros dados obtidos pelo nosso grupo comprovaram que o modelo de indução à obesidade por dieta hipercalórica foi capaz de induzir ganho de peso nos animais (observar Tabela 2). 0 grupo obeso (DH sem $\mathrm{CV}$ ) apresentou um aumento significativo no ganho de peso comparado ao grupo controle (DP sem $\mathrm{CV}$ ). Em relação aos diferentes depósitos de gordura, observamos que todos os depósitos avaliados apresentaram um aumento significativo em relação ao controle. Com isso o IA (índice de adiposidade) avaliado no grupo obeso foi maior ( $49 \%$ ) em relação ao controle. Desta forma, nosso modelo de dieta hipercalórica foi capaz de aumentar o peso corporal dos animais juntamente com o aumento dos depósitos de gordura. Já na condição de obesidade, os animais que receberam o extrato de chá verde (DH com $\mathrm{CV}$ ) apresentaram diminuição 
significativa no ganho de peso, no IA e nos depósitos de gordura em relação ao grupo obeso (DH sem CV) maiores que na condição sem obesidade.

Considerando os efeitos apenas do tratamento com o extrato de chá verde na condição normal (DP com CV), podemos observar uma redução significativa no peso dos animais, uma redução no IA e redução dos depósitos de gorduras em relação ao grupo controle (DP sem CV) (Tabela 2).

Tabela 2 - Caracterização da obesidade pela avaliação do ganho de peso (peso final menos peso inicial dos animais). IA- índice de adiposidade (soma dos pesos dos depósitos de gorduras epididimal, subcutâneo, perirenal e tecido adiposo marrom / $100 \mathrm{~g}$ de peso corporal), e avaliação individual dos pesos dos depósitos de gordura/ $100 \mathrm{~g}$ de peso corporal dos animais.

\begin{tabular}{|c|c|c|c|c|}
\hline & DP sem CV & DP com CV & DH sem CV & DH com CV \\
\hline \multirow[t]{2}{*}{ Ganho de Peso (g) } & $203,5 \pm 11,57$ & $155,2 \pm 11,85^{a}$ & $269,2 \pm 15,52^{b}$ & $164,4 \pm 6,50$ a \\
\hline & & ( $\downarrow 24 \%$ vs. Cont) & $\uparrow(32 \%$ vs. Cont $)$ & ( $\downarrow 39 \%$ vs. Ob) \\
\hline \multirow[t]{2}{*}{ IA (g/100g PC) } & $3,44 \pm 0,35$ & $2,67 \pm 0,14$ & $5,13 \pm 0,30^{b}$ & $3,64 \pm 0,26^{a}$ \\
\hline & & ( $\downarrow 23 \%$ vs. Cont) & $\uparrow(49 \%$ vs. Cont $)$ & ( $\downarrow 30 \%$ vs. Ob) \\
\hline \multirow[t]{2}{*}{ Epididimal (g/100g PC) } & $1,44 \pm 0,05$ & $1,07 \pm 0,08^{a}$ & $1,90 \pm 0,12^{b}$ & $1,33 \pm 0,08^{a}$ \\
\hline & & ( $\downarrow 26 \%$ vs. Cont) & $\uparrow(32 \%$ vs. Cont $)$ & ( $\downarrow 30 \%$ vs. Ob) \\
\hline \multirow[t]{2}{*}{ Subcutâneo (g/100g PC) } & $0,84 \pm 0,06$ & $0,54 \pm 0,05$ & $1,47 \pm 0,13^{b}$ & $0,87 \pm 0,11^{\text {a }}$ \\
\hline & & ( $\downarrow 36 \%$ vs. Cont) & $\uparrow(75 \%$ vs. Cont $)$ & ( $\downarrow 41 \%$ vs. Ob) \\
\hline \multirow[t]{2}{*}{ Perirrenal (g/100g PC) } & $1,06 \pm 0,06$ & $0,94 \pm 0,07$ & $1,65 \pm 0,10^{b}$ & $1,28 \pm 0,08^{a}$ \\
\hline & & ( $\downarrow 11 \%$ vs. Cont) & $\uparrow(55 \%$ vs. Cont $)$ & $(\downarrow 23 \%$ vs. Ob) \\
\hline $\begin{array}{l}\text { Tecido Adiposo Marrom } \\
\text { (g/100g PC) }\end{array}$ & $0,09 \pm 0,01$ & $0,10 \pm 0,01$ & $\begin{array}{l}0,15 \pm 0,01^{b} \\
\uparrow(66 \% \text { vs. Cont })\end{array}$ & $0,14 \pm 0,01$ \\
\hline
\end{tabular}

Os resultados estão apresentados como média \pm EPM de pelo menos 10 animais. $D P=$ dieta padrão, $\mathrm{DH}=$ dieta hipercalórica, $\mathrm{PC}=$ peso corporal e $\mathrm{CV}=$ chá verde. Utilizamos two-way ANOVA com pós teste de Bonferroni, com $\mathrm{p}<0,05$. a= diferente significativamente em relação aos animais sem chá verde tratados com a mesma dieta (DP sem CV ou DH sem CV), b=diferente significativamente do grupo controle (DP sem CV).

Avaliamos também a concentração plasmática de leptina como parâmetro importante para a caracterização da obesidade uma vez que esta é uma importante adipocina secretada pelo tecido branco. Essa adipocina é capaz de informar ao cérebro sobre os estoques de energia do organismo sendo sua produção e concentração sérica proporcional à massa de tecido adiposo. Portanto, é comum observarmos hiperleptinemia em pacientes obesos. Neste caso ocorre resistência à ação desse hormônio ocasionando hiperfagia, redução do gasto energético e 
aumento de peso (CABALLERO, 2007). Como demonstrado na Figura 9 animais obesos (DH sem CV) apresentaram maiores valores de leptina no plasma (30\%, $\mathrm{p}<0.05$ ) em relação ao grupo controle (DP sem $\mathrm{CV}$ ). O tratamento com chá verde não foi capaz de reverter este parâmetro.

Figura 9 - Concentração plasmática de leptina.

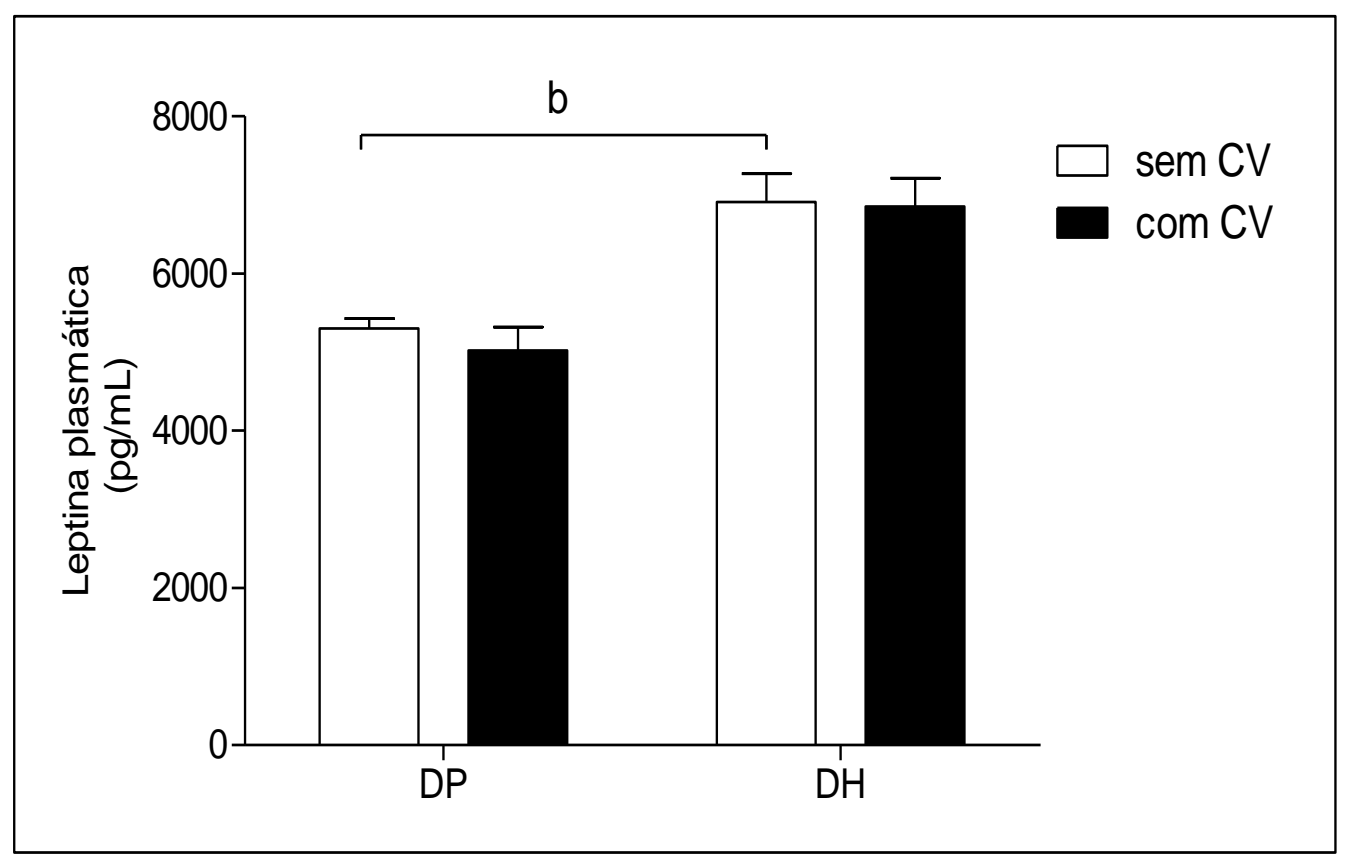

Os resultados estão expressos como média \pm EPM de pelo menos 10 animais. $\mathrm{DP}=$ dieta padrão, $\mathrm{DH}=$ dieta hipercalórica e $\mathrm{CV}=$ chá verde. Utilizamos two-way ANOVA com pós-teste de Bonferroni, com $p<0,05$. $b=$ diferente significativamente do grupo controle (DP sem CV).

A adiponectina também controla a homeostase energética e ao contrário da leptina, sua secreção se encontra diminuída na obesidade e sua concentração plasmática se relaciona inversamente com a obesidade visceral e resistência à insulina, sendo a perda de peso um potente indutor da síntese de adiponectina (CARBONE; LA ROCCA; MATARESE, 2012). Como podemos observar na Figura 10, o grupo obeso (DH sem CV) apresentou um aumento de adiponectina na circulação $(p<0.001)$ em relação ao grupo controle (DP sem $C V)$. Já o tratamento com chá verde, na condição de obesidade (DH com CV), foi capaz de aumentar $(p<0.001)$ a concentração de adiponectina em relação ao grupo $\mathrm{DH}$ sem CV, correlacionando positivamente com a perda de peso observada nos animais que 
receberam o extrato de chá verde. Entretanto, na ausência de obesidade (DP com CV), o chá verde não foi capaz de alterar os níveis dessa adipocina. Esses resultados demonstram que parece haver uma interação entre o chá e a condição de obesidade na elevação da concentração de adiponectina, já que não observamos alteração desta entre os animais que receberam dieta padrão.

Figura 10 - Concentração plasmática de adiponectina

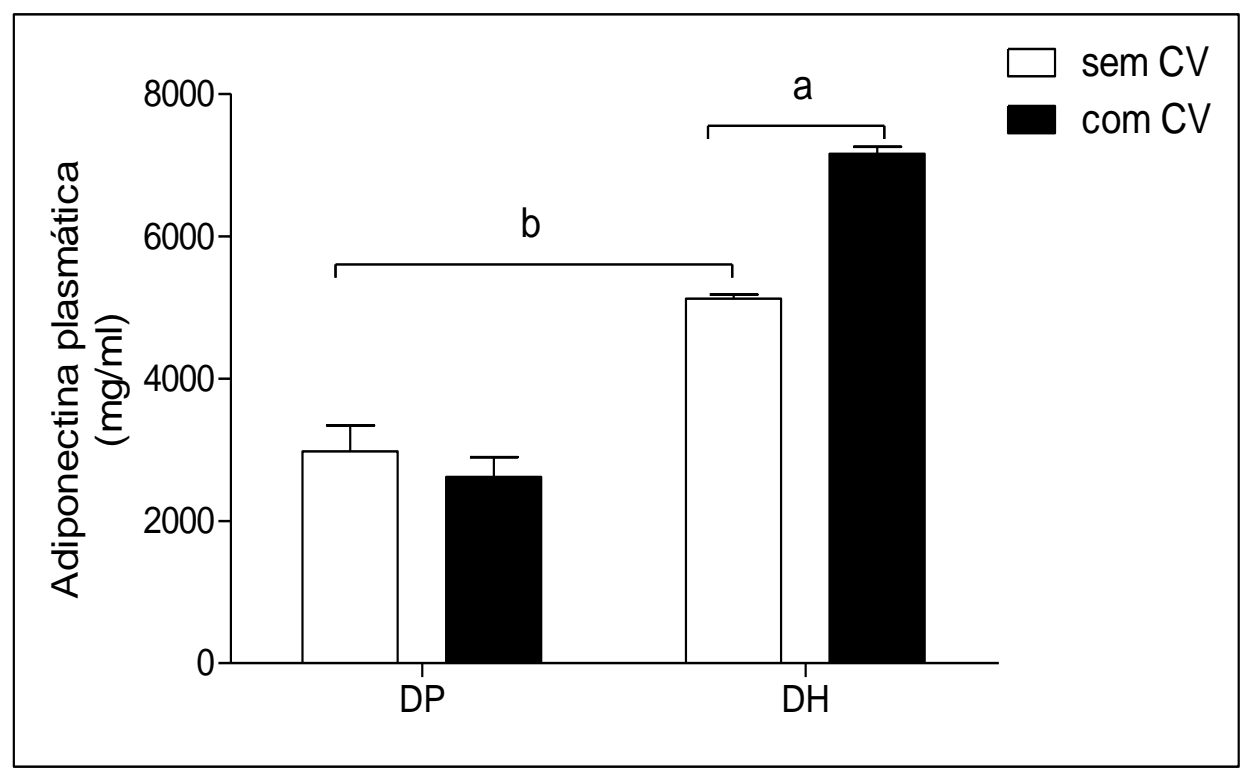

Os resultados estão expressos como média \pm EPM de pelo menos 10 animais. $\mathrm{DP}=$ dieta padrão, $\mathrm{DH}=$ dieta hipercalórica e $\mathrm{CV}=$ chá verde. Para a análise estatística foi utilizado two-way ANOVA com pós-teste de Bonferroni, com $p \leq 0,05 . a=$ diferente significativamente em relação aos animais sem chá verde com a mesma dieta (DP sem $\mathrm{CV}$ ou $\mathrm{DH}$ sem $\mathrm{CV}$ ), b=diferente significativamente do grupo controle (DP sem CV).

A elevação de ácidos graxos livres ( $A G L)$ no plasma é capaz de estimular a resistência à insulina através de duas maneiras distintas: (1) estimulando a gliconeogênese e a glicogenólise, o que resulta em aumento da produção hepática de glicose e indução da resistência à insulina e (2) estabelece um estado inflamatório ao estimular a elevação das adipocitocinas pró-inflamatórias (TNF- $\alpha$, IL6 e leptina) com redução das anti-inflamatórias como a adiponectina (WASSINK; OLIJHOEK; VISSEREN, 2007). Além disso, o excesso de AGL pode se depositar em diferentes tecidos, que não o adiposo, causando o fenômeno conhecido como lipotoxicidade. Nossos dados demonstram que a concentração de ácido graxo livre no plasma apresentou um incremento de $31 \%(p<0.05)$ no grupo obeso $(\mathrm{DH}$ sem 
$\mathrm{CV}$ ) em relação ao grupo controle (DP sem CV). O tratamento com chá verde nos animais obesos (DH com CV) foi capaz de diminuir em 37\% ( $p<0.01)$ em relação ao grupo obeso (Figura 11). A ausência de alteração na concentração de AGL entre os animais que receberam dieta padrão demonstra que o tratamento com o chá verde parece exercer um papel mais significativo sobre os AGL na condição de obesidade.

Figura 11 - Concentração de ácidos graxos livres no plasma

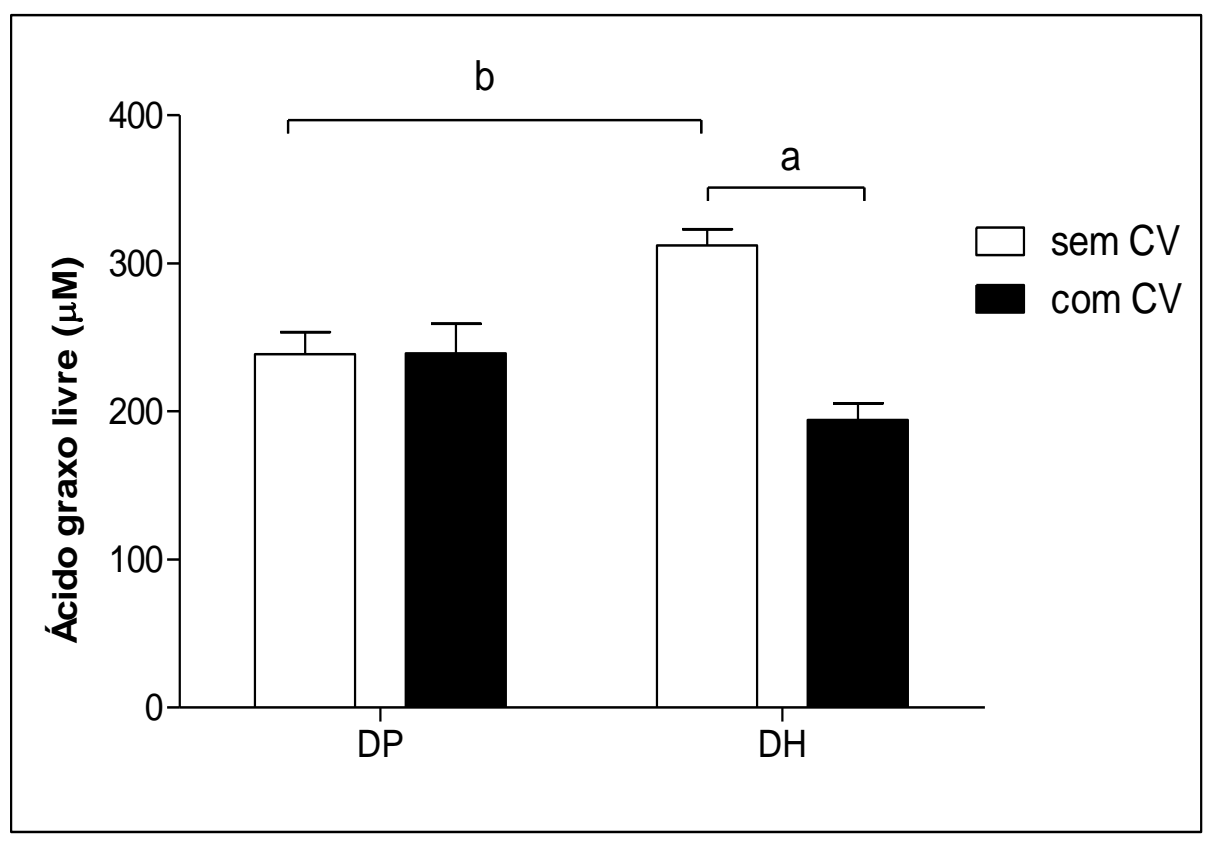

Os resultados estão expressos como média \pm EPM de pelo menos 10 animais. Para a análise estatística foi utilizado two-way ANOVA com pós-teste de Bonferroni, com $p \leq 0,05$. DP= dieta padrão, $\mathrm{DH}=$ dieta hipercalórica e $\mathrm{CV}=$ chá verde. $\mathrm{a}=$ diferente significativamente em relação aos animais sem chá verde tratados com a mesma dieta (DP sem CV ou DH sem CV), b=diferente significativamente do grupo controle (DP sem CV).

Assim, nossos dados demonstram que os animais submetidos à dieta hipercalórica (grupo obeso) apresentaram diferenças significativas em relação ao grupo controle no parâmetro peso final após o período da suplementação, apresentando um incremento no peso do tecido adiposo principalmente dos depósitos de gordura epididimal, retroperitonial e subcutâneo. Este fato foi revertido pela suplementação com chá verde. Além disso, nossos animais após a suplementação com a dieta hipercalórica apresentam resistência à insulina, demonstrada pelos valores obtidos com a análise dos testes de GTT, ITT e Kitt. Os valores elevados de leptina e AGL observados no grupo obeso corroboram para a 
caracterização do quadro de obesidade. O tratamento com chá verde foi capaz de reverter esse quadro, dados também observados por outros autores (BOGDANSKI et al., 2012; WEIN et al., 2013). Além disso, avaliações hepáticas (ALT, AST e GGT) e renais (creatinina e ácido úrico) realizadas nesses animais (dados não apresentados), demonstraram que a suplementação com o extrato de chá verde não foi capaz de causar danos nesses tecidos. Estes resultados em conjunto nos garantiram de que a obesidade estava instaurada nos animais e que as avaliações em linfócitos poderiam ser consideradas como estarem sendo realizadas em linfócitos de animais obesos.

\subsection{Avaliações de parâmetros funcionais de linfócitos}

\subsubsection{Capacidade proliferativa}

Normalmente os linfócitos encontram-se no estado quiescente, mas na presença de antígenos tornam-se ativados e se proliferam rapidamente, o que faz com que a resposta imunitária seja eficiente contra antígenos invasores. A mudança para o estado ativado é também acompanhada por alterações metabólicas nestas células e as vias biossintéticas e energéticas são estimuladas (PEARCE; PEARCE, 2013; SHIPKOVA; WIELAND, 2012). Os linfócitos T quando ativados através da ligação de agonistas aos seus receptores de membrana, proliferam e podem secretar mediadores químicos para outras células, como por exemplo, as infectadas por vírus, ou funcionam como auxiliares ativando macrófagos e outros linfócitos. Esses linfócitos proliferam in vitro quando estimulados por mitógenos como a concanavalina A (Con A). A estimulação dos linfócitos com o mitógeno Con A envolve a ativação de uma cascata complexa de reações bioquímicas, que promove a entrada das células no ciclo celular e os linfócitos quiescentes se transformam em linfoblastos metabolicamente ativos (DORN et al., 2002).

A concanavalina $A$ (Con $A$ ) é uma proteína globular de origem vegetal, obtida a partir da Canavalia ensiformis. Devido às suas propriedades bioquímicas, a Con $A$ foi classificada por SUMNER e HOWELL (1936) como uma lecitina. Estudos realizados demonstram que a Con A é um excelente indutor de mitose em linfócitos, especialmente linfócitos $\mathrm{T}$. Os linfócitos $\mathrm{B}$ proliferam in vitro em resposta a lipopolissacarídeos (LPS) (ARDAWI; NEWSHOLME, 1982; CALDER, 1998) e 
quando ativados são chamados de plasmócitos e são capazes de secretar anticorpos conhecidos como imunoglobulinas.

$\mathrm{Na}$ Figura 12 podemos observar que na condição basal (sem estímulo mitogênico), os animais obesos ( $\mathrm{DH}$ sem CV) apresentaram um aumento (27\%, $\mathrm{p}<0.01$ ) significativo na capacidade proliferativa em relação ao controle (DP sem CV). Por sua vez, os animais que receberam chá verde apresentaram uma redução na capacidade proliferativa $(34 \%, p<0.001)$ na condição de obesidade (DH com CV).

A avaliação da capacidade proliferativa dos linfócitos na presença dos estímulos LPS e Con A teve como objetivo avaliar a qualidade da resposta dessas células contra antígenos. Entretanto, na presença desses dois mitógenos, o grupo obeso (DH sem CV) não apresentou alteração significativa na proliferação celular. Em contrapartida, o tratamento com chá verde foi capaz de reduzir a capacidade proliferativa dessas células. Na presença de Con A, o grupo DH com CV apresentou uma diminuição de $34 \%(p<0.001)$ em relação ao grupo obeso ( $D H$ sem $C V$ ), demonstrando assim que o chá verde é capaz de reduzir significativamente a proliferação de linfócitos $T$ na condição de obesidade, tendo pouco efeito na ausência desta condição. Sob o estímulo de LPS, o chá verde apresentou uma redução na proliferação de linfócitos $B(25 \%, p<0.01)$ em relação ao grupo controle (DP sem CV), porém não foi capaz de alterar este parêmetro na presença da obesidade. 
Figura 12 - Capacidade proliferativa

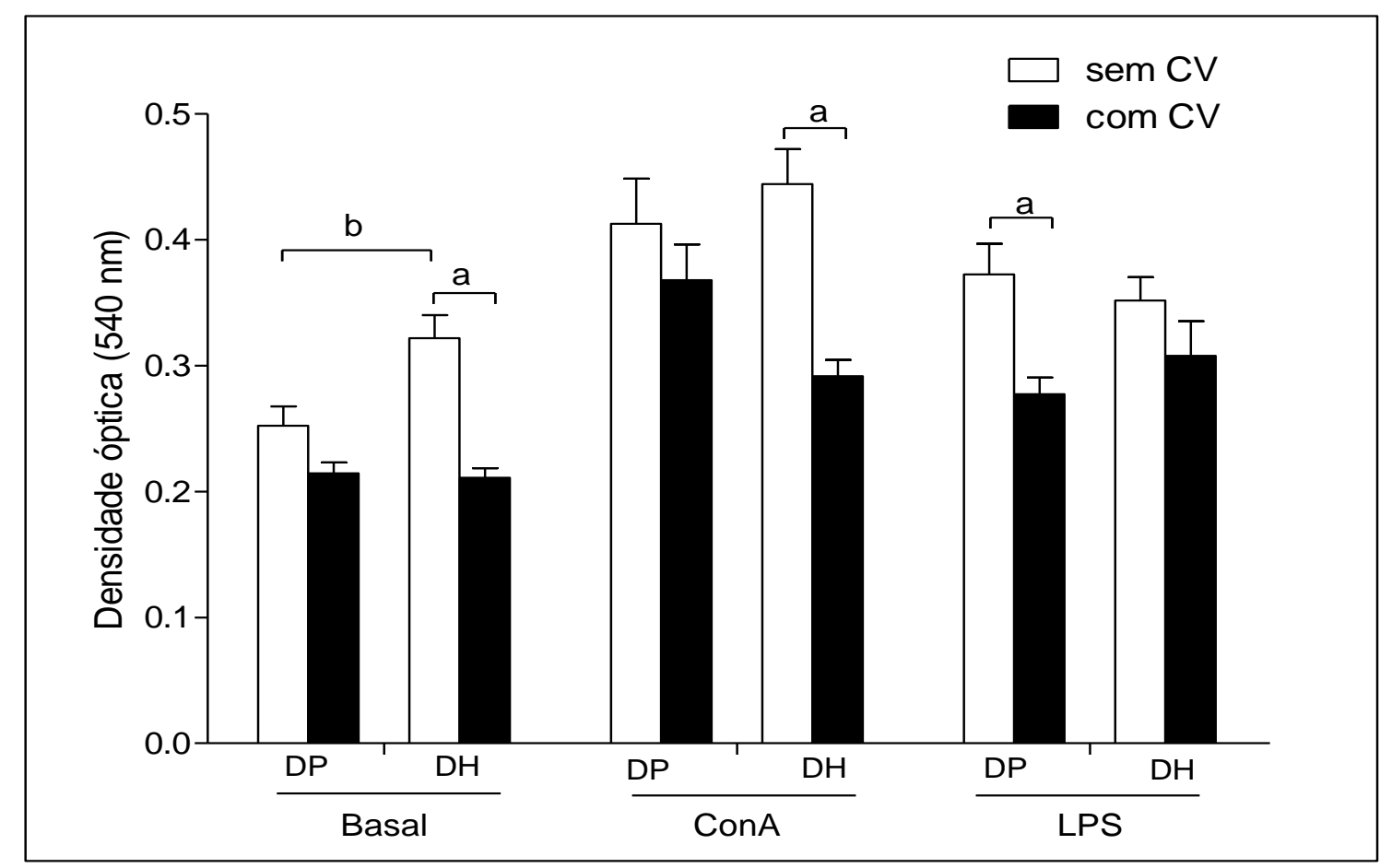

Proliferação de linfócitos realizado pela incorporação de BrdU em células cultivadas por 48 h na condição sem estímulo (basal) ou na presença do mitógeno Con A e LPS. O ensaio foi realizado nos animais que receberam dieta padrão (DP) - com e sem chá verde e nos animais que receberam dieta hipercalórica $(\mathrm{DH})$ com ou sem chá verde. Os resultados estão apresentados como média \pm EPM da densidade ótica de 10 animais obtida em avaliações realizadas em triplicata. A análise estatística foi realizada por Two-way ANOVA com pós-teste de Bonferroni, com $p<0,05$. $\mathrm{DP}=$ dieta padrão, $\mathrm{DH}=$ dieta hipercalórica e $\mathrm{CV}=$ chá verde. $\mathrm{a}=$ diferente significativamente em relação aos animais sem chá verde tratados com a mesma dieta (DP sem CV ou DH sem CV), b=diferente significativamente do grupo controle (DP sem CV).

\subsubsection{Produção de citocinas pró- e anti-inflamatórias}

As citocinas possuem papel importante na sinalização dos fenômenos de regulação da homeostase do organismo e estão envolvidas na emissão de sinais de comunicação durante o desencadeamento das respostas imunes (ROMAGNANI, 1994). Na avaliação da produção de IL-2 (Tabela 3), na qual os linfócitos foram previamente cultivados por $24 \mathrm{~h}$ na presença do estímulo Con A (10 $\mathrm{\mu g} / \mathrm{ml})$, o grupo tratado com chá verde na condição de obesidade (DH com CV) apresentou uma diminuição significativa $(43 \%, p<0.001)$ de IL-2 em relação ao grupo obeso $(\mathrm{DH}$ sem CV). 
A produção de IL-1 $\beta$, IL-6 e TNF- $\alpha$ (Tabela 3 ) avaliadas no sobrenadante de linfócitos de ratos previamente cultivados por $18 \mathrm{~h}$ na presença do estímulo de LPS (80 $\mathrm{\mu g} / \mathrm{ml})$ foi modulada pelo tratamento com chá verde em ambas as condições: ausência e presença de obesidade.

O grupo tratado com chá verde na ausência de obesidade (DP com CV) mostrou uma diminuição significativa na produção de IL-1 $\beta$ de $55 \%(p<0.01)$ em relação ao grupo controle (DP sem $\mathrm{CV}$ ), enquanto que o chá verde na condição de obesidade (DH com CV) diminuiu de forma significativa essa citocina em $44 \%$ $(p<0.05)$ em relação ao grupo obeso (DH sem $C V)$.

A produção de IL-6 teve redução significativa com o tratamento de chá verde em $8 \%$ e $7 \%(p<0.01)$ nos grupos DP com CV e DH com CV em relação ao controle (DP sem CV) e obeso (DH sem CV), respectivamente.

A produção de TNF- $\alpha$ apresentou-se reduzida (36\% e 40\%, $p<0.001$ ) nos dois grupos que receberam chá verde (DP com CV e DH com CV) em relação ao grupo controle (DP sem CV) e ao grupo obeso (DH sem CV), respectivamente.

A produção do IFN-y (Tabela 3) avaliada no sobrenadante de linfócitos de ratos previamente cultivados por $24 \mathrm{~h}$ na presença do estímulo PMA (100 ng/ml) e ionomicina $(500 \mathrm{ng} / \mathrm{ml})$, não foi alterada em nenhum dos grupos.

A IL-10 (Tabela 3) avaliada no sobrenadante de linfócitos de ratos previamente cultivados por $24 \mathrm{~h}$ na presença do estímulo LPS $(80 \mu \mathrm{g} / \mathrm{ml})$ e ConA (10 $\mu \mathrm{g} / \mathrm{ml}$ ), apresentou uma diminuição de $43 \%(p<0.01)$ no grupo obeso ( $\mathrm{DH}$ sem $\mathrm{CV}$ ) quando comparado com o grupo controle (DP sem $\mathrm{CV}$ ), e o tratamento com chá verde nessa condição ( $\mathrm{DH}$ com $\mathrm{CV}$ ) foi capaz de aumentar $(64 \%, \mathrm{p}<0.05)$ a produção dessa citocina.

Esses dados indicam que a dieta hipercalórica per se apresentou efeito importante em nosso modelo apenas na redução da IL-10. Já o tratamento com o chá verde mostrou-se efetivo na redução das citocinas produzidas por linfócitos estimulados com LPS, independente da presença da obesidade, não apresentando interação com esta, pois as reduções na produção das citocinas apresentaram valores similares em ambas às condições. 
TABELA 3 - Produção de citocinas por linfócitos

\begin{tabular}{|c|c|c|c|c|c|}
\hline & Basal & $\begin{array}{c}\text { DP sem CV + } \\
\text { estímulo }\end{array}$ & DP com CV & $\mathrm{DH}$ sem CV & $\mathrm{DH}$ com CV \\
\hline IL-2 & $130,8 \pm 17,7$ & $277,2 \pm 19,5$ & $315,2 \pm 20,0$ & $254,4 \pm 13,9$ & $145,0 \pm 14,2^{(a)}$ \\
\hline TNF- $\alpha$ & $80,3 \pm 3,7$ & $139,9 \pm 13,4$ & $89,7 \pm 10,5^{(a)}$ & $143,9 \pm 7,8$ & $71,9 \pm 7,6^{(a)}$ \\
\hline IL-1 $\beta$ & $1064,0 \pm 22,9$ & $2549,0 \pm 22,8$ & $1143,0 \pm 39,8^{(a)}$ & $2228,0 \pm 364,9$ & $1243,0 \pm 240,6^{(a)}$ \\
\hline IFN-p & $522,0 \pm 32,1$ & $1061,0 \pm 254,7$ & $819,4 \pm 82,2$ & $771,2 \pm 96,3$ & $753,0 \pm 96,8$ \\
\hline IL-6 & $2202,0 \pm 42,2$ & $2500,0 \pm 30,5$ & $2310,0 \pm 47,8^{(a)}$ & $2409,0 \pm 38,4$ & $2240 \pm 21,4^{(a)}$ \\
\hline IL-10 & $1060,0 \pm 253,4$ & $4886,0 \pm 279,9$ & $4406,0 \pm 85,9$ & $2984,0 \pm 498,4^{(b)}$ & $4895,0 \pm 114,7^{(a)}$ \\
\hline
\end{tabular}

Os resultados foram expressos como média \pm EPM de pelo menos 6 animais $(\mathrm{pg} / \mathrm{mL})$ utilizando como análise estatística Two-way ANOVA com pós-teste de Bonferroni e $p<0.05$. Para a análise foram utilizados diferentes estímulos e tempo de incubação de acordo com o tipo de citocina conforme materiais e métodos. $\mathrm{DP}=$ dieta padrão, $\mathrm{DH}=$ dieta hipercalórica e $\mathrm{CV}=$ chá verde $\mathrm{a}=$ diferente significativamente em relação aos animais sem chá verde tratados com a mesma dieta (DP sem CV ou DH sem CV), b=diferente significativamente do grupo controle (DP sem CV).

\subsubsection{Liberação intracelular de cálcio}

Em células do sistema imunológico, incluindo células T e B, mastócitos entre outros, os sinais de cálcio controlam processos como proliferação, diferenciação, apoptose e uma variedade de programas de transcrição gênica (HOGAN et al., 2003; HOGAN; RAO, 2007; LEWIS, 2007).

Em períodos de tempo curtos (minutos) a entrada de $\mathrm{Ca}^{2+}$ é necessária para a desgranulação dos mastócitos e para lise de células infectadas (DI CAPITE; PAREKH, 2009; PORES-FERNANDO; ZWEIFACH, 2009). Em longo prazo (horas), a entrada sustentada de $\mathrm{Ca}^{2+}$ é fundamental para essencialmente todas as respostas iniciadas através de células $T$ e $B$ e receptores $F c$, incluindo proliferação e produção de citocinas por células $T$, produção de citocinas pelos mastócitos $\mathrm{e}$ células natural killer (OZCAN et al.), diferenciação de células $B$ em plasmócitos, diferenciação de células T em subtipos efetores como as células Th1, Th2 e Th17. Muitos destes processos em longo prazo são regulados pelo fator de transcrição 
NFAT (fator nuclear de células $T$ ativadas), que está presente em um estado altamente fosforilado no citoplasma de células em repouso, mas que se torna desfosforilado e se transloca para o núcleo quando há elevação de $\left[\mathrm{Ca}^{2+}\right]_{i}$ que ativa a fosfatase calcineurina dependente de cálcio-calmodulina (DEYULIA et al.; HOGAN et al., 2003; MACIAN, 2005).

$\mathrm{Na}$ Figura 13 apresentamos os resultados obtidos com a avaliação da liberação de cálcio intracelular realizados com a ajuda da sonda Fura 2-AM em linfócitos de ratos suplementados ou não com o extrato de chá verde. No gráfico que apresenta AUC, observamos que não houve diferenças na mobilização intracelular de cálcio em todos os grupos avaliados.

Figura 13 - Avaliação da mobilização intracelular de cálcio em linfócitos

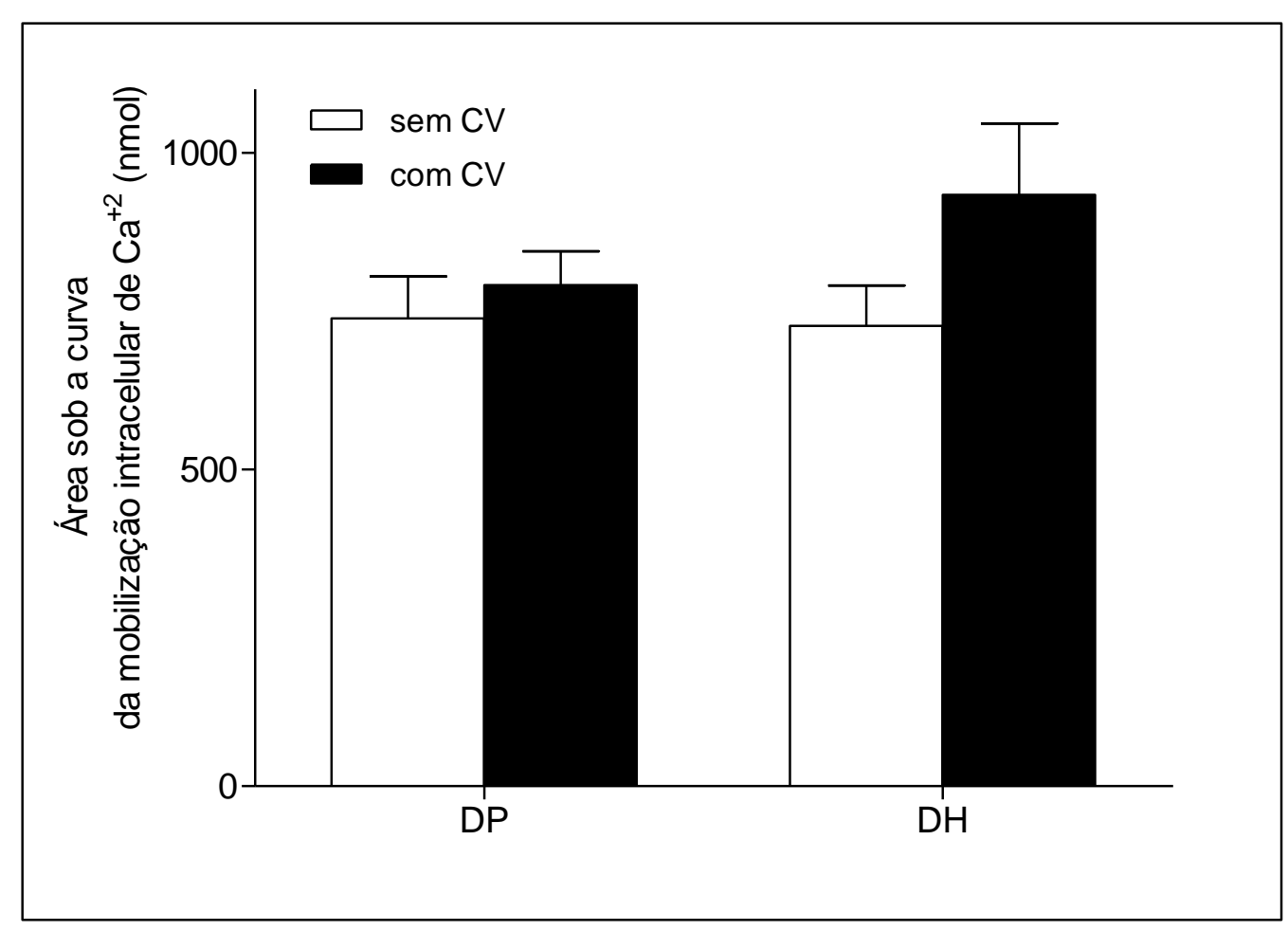

As células $1 \times 10^{6}$ foram previamente incubadas com Fura-2 AM (5 $\left.\mu \mathrm{M}\right)$ durante $1 \mathrm{~h}$. O ensaio foi realizado nos animais na condição DP (dieta padrão) com e sem chá e nos animais na condição DH (dieta hipercalórica) com e sem chá verde. $\mathrm{DP}=$ dieta padrão, $\mathrm{DH}=$ dieta hipercalórica e $\mathrm{CV}=$ chá verde. Os resultados estão apresentados como média \pm EPM da somatória da liberação total de cálcio durante 20 min em 4 animais por grupo. A análise estatística utilizada foi Two-way ANOVA com pós-teste de Bonferroni, adotando $\mathrm{p}<0.05$. 


\subsubsection{Produção de EROs}

O burst respiratório pode ser verificado em fagócitos e linfócitos B pela catálise realizada pela enzima NADPH-oxidase onde ocorre a produção de superóxido $\left(\mathrm{O}_{2}^{-\bullet}\right)$. $\mathrm{O} \mathrm{O}_{2}^{-\bullet}$ gerado por esta enzima serve como substrato inicial para a produção de diversos outros radicais livres. Estes oxidantes são utilizados por fagócitos para matar microorganismos invasores, mas podem causar uma série de efeitos colaterais. A formação de $\mathrm{O}_{2}^{-\bullet}$ em linfócitos $B$ ainda não está clara, tendo em vista que estas células não apresentam atividade microbicida (MALY et al., 1989). Entretanto, recentemente Reth $(\mathrm{RETH}, 2002)$ relatou que o peróxido de hidrogênio atua como um segundo mensageiro em linfócitos B. Na membrana plasmática de linfócitos B, está presente a enzima NADPH-oxidase, responsável por catalisar a redução de oxigênio utilizando o co-fator NADPH.

Neste estudo a produção de EROs foi avaliada pelo ensaio das sondas fluorescentes DCFH-DA e DHE. Os ensaios foram realizados na condição basal ou com o estímulo do burst induzido pela adição de PMA. O PMA sendo um análogo do diacilglicerol causa ativação da PKC, e esta é capaz de fosforilar a subunidade citoplasmática $\mathrm{p} 47^{\text {phox }}$ do complexo enzimático NADPH oxidase, causando sua translocação e interação com as subunidades membranares do complexo. Essa interação leva à ativação do complexo, com posterior produção de ânion superóxido.

Como mostra a Figura 14A (ensaio com DHE), na ausência ou presença de PMA, o grupo obeso (DH sem CV) apresentou um aumento significativo (42\% e $32 \%$ com $p<0.01$, respectivamente) na produção de EROs em relação ao grupo controle (DP sem CV). Em relação ao tratamento com chá verde, podemos observar uma diminuição na produção de EROs apenas na condição de obesidade (DH com CV) tanto na ausência $(50 \%, \mathrm{p}<0.001)$ como na presença $(51 \%, \mathrm{p}<0.001)$ de PMA em relação ao grupo obeso (DH sem $\mathrm{CV})$.

A partir dos resultados obtidos com a sonda DCFH-DA (Figura 14B) observamos um aumento significativo na produção de EROs na condição de obesidade ( $\mathrm{DH}$ sem $\mathrm{CV}$ ) em relação ao controle (DP sem CV), tanto na ausência $(41 \%, p<0.01)$ quanto na presença $(34 \%, p<0.01)$ de PMA. As células tratadas com chá verde foram capazes de modular a produção de EROs apenas na condição de obesidade (DH com CV) em relação ao grupo obeso (DH sem CV), que apresentou uma diminuição significativa em $32 \%(p<0.001)$. 
Esses resultados demonstram que de fato a dieta hipercalórica foi capaz de modular a produção de EROs pelos linfócitos, independente da utilização do estímulo PMA como indutor de burst respiratório. O aumento de EROs observado no grupo obeso (DH sem CV) em relação ao controle (DP sem CV) apresentou valores em porcentagens similares, independente da presença do PMA e do ensaio utilizado (DCFH-DA ou DHE). Em relação ao tratamento com o chá verde podemos observar que este apresentou efeito significativo apenas na condição de obesidade, sem alteração nos grupos que receberam dieta padrão; demonstrando assim haver uma interação do tratamento com o chá verde com a dieta hipercalórica, causando redução da produção de EROs evidenciado pelas sondas DCFH-DA e DHE.

Figura 14 - Avaliação da produção de espécies reativas de oxigênio pela sonda $\operatorname{DHE}(\mathrm{A})$ e DCFH-DA (B)

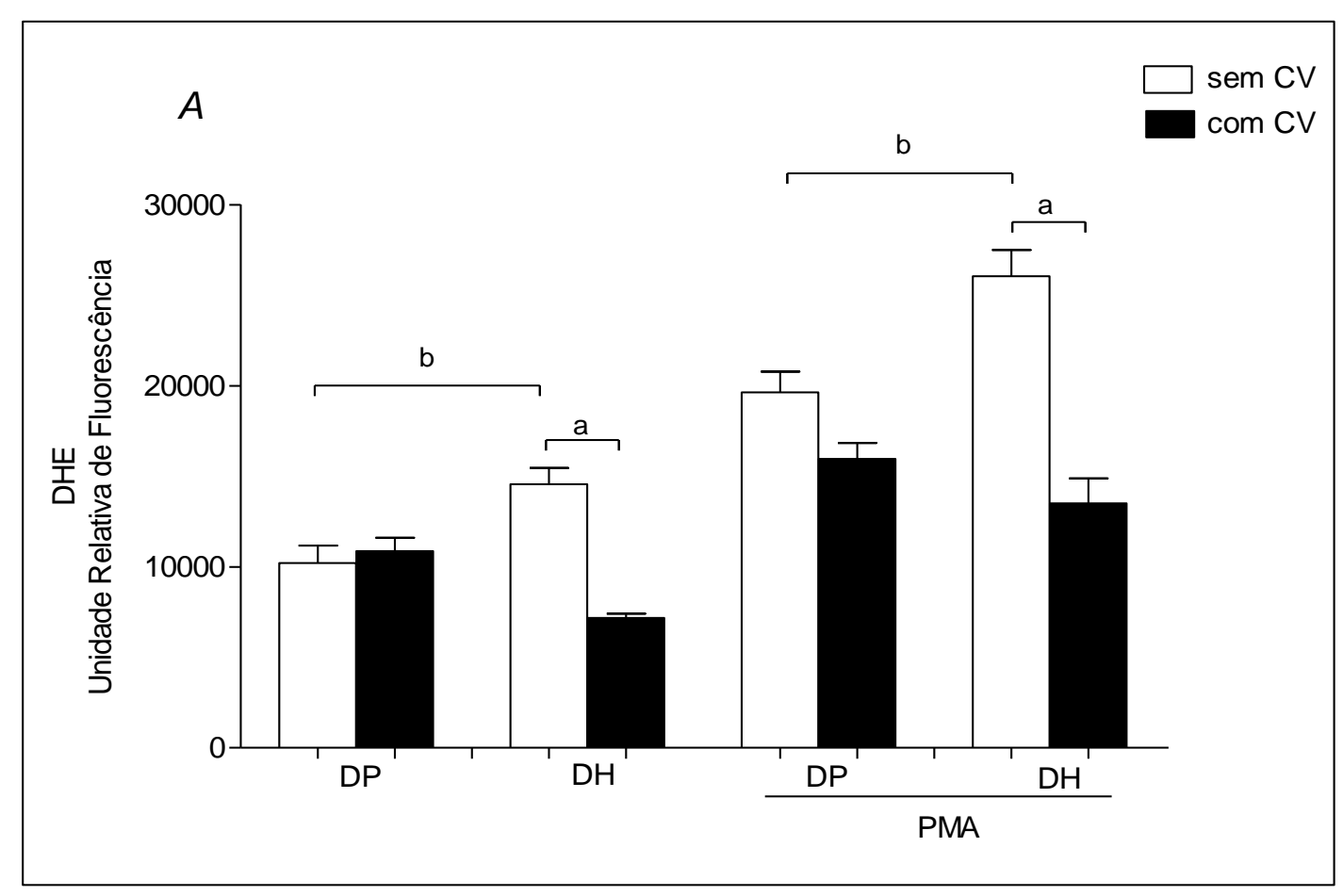




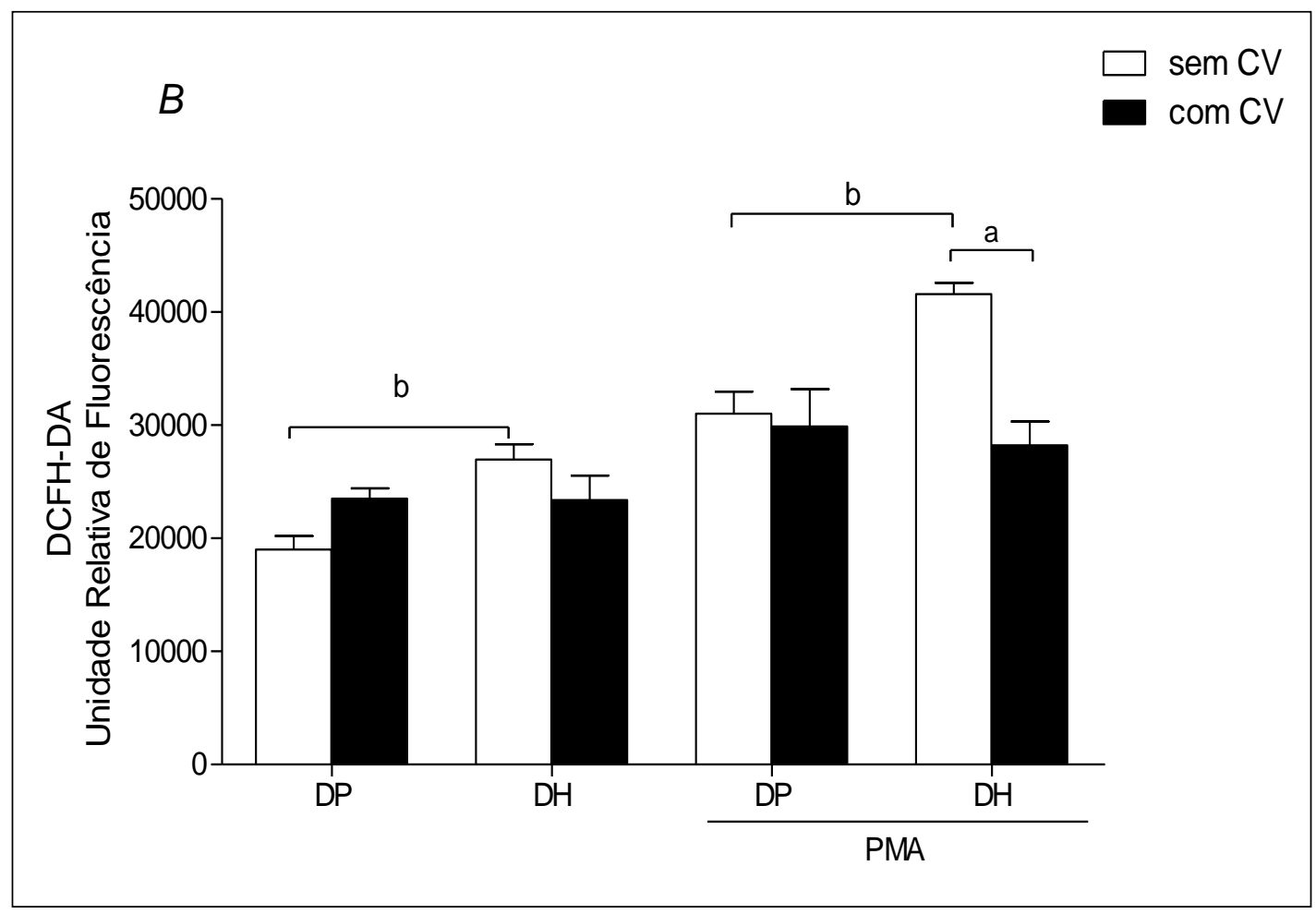

Produção de EROs pelos linfócitos de ratos na ausência e na presença de PMA. O ensaio foi realizado nos animais na condição DP (dieta padrão) - com e sem chá verde, e nos animais na condição DH (dieta hipercalórica) - com e sem chá verde. Os resultados estão apresentados como média \pm EPM de um experimento contendo 10 animais e realizado em triplicata. A análise estatística utilizada foi Two-way ANOVA com pós-teste de Bonferroni, adotando $\mathrm{p}<0.05$. $\mathrm{DP}=$ dieta padrão, $\mathrm{DH}=$ dieta hipercalórica e $C V=$ chá verde. $a=$ diferente significativamente em relação aos animais sem chá verde tratados com a mesma dieta (DP sem CV ou DH sem CV), b=diferente significativamente do grupo controle (DP sem CV).

\subsubsection{Atividade das enzimas SOD, Cat, GPx e GR}

As enzimas antioxidantes fazem parte de um potente mecanismo celular na defesa do organismo contra a produção excessiva de EROs. As defesas antioxidantes primárias, incluem as enzimas superóxido dismutase (SOD), glutationa peroxidase (GPx), catalase (Cat), glutationa-S-transferase (GST) entre outras que não participam diretamente do processo, mas fornecem suporte para a GPx como a glicose-6-fosfato desidrogenase (G6PDH) e a glutationa redutase (GR) (DROGE, 2002; HALLIWELL; GUTTERIDGE, 2006). As defesas não enzimáticas também participam desse processo como a vitamina E, C, flavonóides, carotenóides e outras moléculas como a glutationa, além das tioredoxinas, oxidoredutases dissulfetos que também participam da manutenção da homeostase tiol redox (KOHARYOVA; KOLAROVA, 2008). 
Como podemos observar na Tabela 4, houve uma tendência ao aumento da atividade da SOD-Mn em todos os grupos comparado ao controle (DP sem CV); entretanto apenas no grupo DP com CV houve aumento significativo de 95\% $(p<0.05)$ em relação ao grupo controle (DP sem CV).

Em relação à isoforma $\mathrm{Cu} / \mathrm{Zn}$, o grupo obeso (DH sem $\mathrm{CV}$ ) apresentou um aumento de $82 \%(p<0.001)$ em relação ao grupo controle (DP sem CV). Já o tratamento com o chá verde apresentou um aumento de $46 \%(p<0.01)$ na ausência de obesidade comparado ao grupo controle (DP sem CV). Em contrapartida o grupo DH com CV apresentou uma diminuição significativa de $32 \%(p<0.001)$ na atividade dessa enzima em relação ao grupo obeso (DH sem $\mathrm{CV}$ ). Esses resultados demonstram que a dieta influencia no efeito do chá verde sobre a atividade da enzima SOD Cu/Zn.

Em relação às enzimas que degradam o peróxido de hidrogênio proveniente da dismutação do ânion superóxido, nenhum dos grupos avaliados apresentou alteração na atividade da catalase. O tratamento com chá verde na condição de obesidade apresentou um aumento significativo ( 2 vezes, $\mathrm{p}<0.001$ ) na atividade da GPx em relação ao grupo obeso (DH sem CV).

$\mathrm{Na}$ atividade da GR observamos que o grupo obeso apresentou um aumento expressivo de 3 vezes $(p<0.01)$ em relação ao grupo controle (DP sem $C V$ ). $O$ tratamento com chá verde foi capaz de modular a atividade da GR independente da obesidade, apresentando um aumento similar de 3 vezes na atividade $(p<0.001)$ em relação ao grupo controle (DP sem $C V)$ e $72 \%(p<0.01)$ em relação ao grupo obeso (DH sem CV).

\subsubsection{Razão das glutationas}

O sistema GSH/GSSG é o sistema redox mais abundante em células eucarióticas, e, portanto possui um papel fundamental na homeostase celular. A glutationa reduzida $(\mathrm{GSH})$ é um co-fator para a glutationa peroxidase na decomposição de peróxidos de hidrogênio ou peróxidos orgânicos. Alterações quantitativas e qualitativas do sistema redox GSH/GSSG são considerados índices de danos oxidativos.

Como podemos observar na Tabela 4, o conteúdo de glutationa reduzida (GSH) e glutationa oxidada (GSSG) não foram alterados em nenhum dos grupos 
avaliados. Entretanto, quando realizamos a razão GSH/GSSG observamos que o tratamento com o chá verde, na condição de obesidade, foi capaz de aumentar 2 vezes $(p<0.05)$ a razão da glutationa reduzida/oxidada em relação ao grupo obeso (DH sem CV).

\subsubsection{Atividade das enzimas metabólicas Hexoquinase e G6PDH}

O metabolismo da glicose é de fundamental importância para os organismos vivos. Células T utilizam glicose e glutamina como suas primeiras fontes de energia (BENTAL; DEUTSCH, 1993). Corpos cetônicos e ácidos graxos também podem ser utilizados em quantidades menores. Destes nutrientes, a glicose parece ser necessária para a sobrevivência celular, crescimento, ativação e produção de citocinas (FOX; HAMMERMAN; THOMPSON, 2005).

Para a geração de ATP, a glicose pode ser metabolizada pela via glicolítica ou sofrer oxidação completa via fosforilação oxidativa (FOX; HAMMERMAN; THOMPSON, 2005). Nessa etapa, a função da hexoquinase na regulação do metabolismo de carboidrato é bem conhecida e essencial, sendo a primeira enzima a atuar sobre a glicose transformando-a em glicose-6-fosfato que é o principal substrato para as vias metabólicas. A atividade da hexoquinase é inibida pelo próprio produto da reação, sendo ativada na falta deste (CHAMP, 1994).

A atividade da hexoquinase (Tabela 4) na obesidade (DH sem CV) mostrouse aumentada em 50\% ( $p<0.001)$ em relação ao grupo controle (DP sem CV). Já o tratamento com o chá verde, na condição de obesidade, ocasionou uma diminuição $(21 \%, p<0.05)$ na atividade dessa enzima em relação ao grupo obeso (DH sem CV).

A glicose pode servir também como fonte de carbono para a síntese de outras macromoléculas, como ácidos nucleicos e fosfolipídeos e também ser metabolizada pela via das pentoses para gerar NADPH. A G6PDH cataliza a primeira reação da via da hexose monofosfato na qual a glicose-6-fosfato é oxidada a 6fosfogluconolactona com a redução concomitante de NADP a NADPH. O NADPH gerado nesta via é essencial na proteção das células contra a ação de oxidantes por manter a glutationa no estado reduzido (GSH) (BEUTLER, 1994).

A atividade da G6PDH (Tabela 4) foi diminuída significativamente com 0 tratamento de chá verde, independente da condição de obesidade, apresentando 
uma diminuição de 30\% $(p<0.001)$ em relação ao controle (DP sem CV) e 49\% $(p<0.001)$ em relação ao obeso (DH sem CV).

Tabela 4 - A atividade das enzimas antioxidantes SOD-Mn, SOD-Cu/Zn, catalase, GPx, GR, razão GSH/GSSG e atividade das enzimas metabólicas Hexoquinase e G6PDH

\begin{tabular}{|c|c|c|c|c|}
\hline & DP sem CV & DP com CV & DH sem CV & $\mathrm{DH}$ com CV \\
\hline $\begin{array}{l}\text { SOD Mn (U/mg } \\
\text { de proteína) }\end{array}$ & $4,96 \pm 0,43$ & $9,68 \pm 1,79^{(a)}$ & $7,25 \pm 0,94$ & $9,13 \pm 1,08$ \\
\hline $\begin{array}{l}\text { SOD Cu/Zn } \\
\text { (U/mg de } \\
\text { proteína) }\end{array}$ & $8,99 \pm 0,58$ & $13,17 \pm 0,87^{(a)}$ & $16,40 \pm 1,19^{(b)}$ & $11,07 \pm 0,75^{\text {(a) }}$ \\
\hline $\begin{array}{c}\text { Catalase } \\
\text { (umol } / \mathrm{min} / \mathrm{mg} \text { de } \\
\text { proténa) }\end{array}$ & $1,54 \pm 0,19$ & $1,46 \pm 0,21$ & $1,39 \pm 0,17$ & $1,24 \pm 0,17$ \\
\hline $\begin{array}{c}\mathrm{GPx} \\
\text { (mU/mg de } \\
\text { proteína) }\end{array}$ & $6,15 \pm 0,57$ & $6,59 \pm 0,48$ & $7,01 \pm 0,41$ & $15,70 \pm 2,80^{\text {(a) }}$ \\
\hline $\begin{array}{c}\mathrm{GR} \\
\text { (mU/mg de } \\
\text { proteína) }\end{array}$ & $194,2 \pm 24,3$ & $650,9 \pm 68,9^{(a)}$ & $644,3 \pm 30,26^{(b)}$ & $1114,0 \pm 111,0^{(a)}$ \\
\hline $\begin{array}{c}\text { GSH } \\
(\mu \mathrm{M} / \mathrm{mg} \text { of } \\
\text { protein })\end{array}$ & $0,25 \pm 0,03$ & $0,21 \pm 0,01$ & $0,19 \pm 0,01$ & $0,25 \pm 0,02$ \\
\hline $\begin{array}{c}\text { GSSG } \\
(\mu \mathrm{M} / \mathrm{mg} \text { of } \\
\text { protein) }\end{array}$ & $0,07 \pm 0,01$ & $0,07 \pm 0,01$ & $0,09 \pm 0,02$ & $0,07 \pm 0,01$ \\
\hline GSH/GSSG & $2,13 \pm 0,83$ & $2,71 \pm 1,16$ & $1,43 \pm 0,52$ & $4,06 \pm 0,17^{(a)}$ \\
\hline $\begin{array}{l}\text { Hexoquinase } \\
\text { (nmol/min/proteína) }\end{array}$ & $2,74 \pm 0,17$ & $3,05 \pm 0,12$ & $4,13 \pm 0,26^{(b)}$ & $3,25 \pm 0,31^{(\mathrm{a})}$ \\
\hline $\begin{array}{c}\text { G6PDH } \\
\text { (nmol/min/mg de } \\
\text { proteína) }\end{array}$ & $4,32 \pm 0,08$ & $3,00 \pm 0,21^{(a)}$ & $4,39 \pm 0,40$ & $2,25 \pm 0,17^{(a)}$ \\
\hline
\end{tabular}

Os valores estão expressos como media \pm EPM de 10 animais por grupo. A análise estatística utilizada foi Two-way ANOVA com pós-teste de Bonferroni, adotando $p<0.05$. O ensaio foi realizado nos animais na condição DP (dieta padrão) com e sem e chá e nos animais na condição DH (dieta hipercalórica) com e sem chá verde. $\mathrm{DP}=$ dieta padrão, $\mathrm{DH}=$ dieta hipercalórica e $\mathrm{CV}=$ chá verde. $\mathrm{a}=$ diferente significativamente em relação aos animais sem chá verde tratados com a mesma dieta (DP sem CV ou DH sem CV), b=diferente significativamente do grupo controle (DP sem CV). 


\section{DISCUSSÃO}

Existem muitas evidências na literatura indicando que o excesso de adiposidade ocasiona um impacto negativo na função imunológica e na defesa do organismo tanto em indivíduos obesos quanto em modelos animais. De fato, animais induzidos à obesidade por dieta mimetizam a obesidade humana, pois são capazes de desenvolver comorbidades típicas associadas com a obesidade, incluindo elevações de leptina circulante, resistência à insulina e elevação de ácidos graxos e triacilgliceróis (MILNER; BECK, 2012).

Os dados deste estudo demonstraram que os animais submetidos à dieta hipercalórica apresentaram diferenças significativas em relação ao grupo controle no parâmetro peso final após o período da suplementação, apresentando um incremento no peso do tecido adiposo principalmente dos depósitos de gordura epididimal, retroperitonial e subcutâneo. Além disso, nossos animais após a suplementação com a dieta de cafeteria apresentaram resistência à insulina, evidenciada pelos valores obtidos com a análise AUC do teste de GTT e ITT.

Os valores elevados de leptina e ácidos graxos livres observados no grupo obeso corroboram também para a caracterização do quadro de obesidade. Em contrapartida, em nosso modelo foi observado um aumento de adiponectina plasmática. Entretanto, o aumento de adiponectina total mensurada no plasma pode não ser a forma mais ativa dessa adipocina. De acordo com (YAMAUCHI; KADOWAKI, 2013) a adiponectina pode existir no plasma em três diferentes formas constituindo complexos multiméricos (trímeros de baixo peso molecular, hexameros de médio peso molecular e 12-18meros de alto peso molecular - HMW). A forma HMW parece ser mais potencialmente efetiva na ativação da enzima AMPK (HADA et al., 2007; KOBAYASHI et al., 2004) e assim, nas ações benéficas da adiponectina. Além disso, a razão adiponectina HMW plasmática/adiponetina total correlaciona-se mais significativamente com os níveis de glicose e insulina do que a adiponectina total, sugerindo que alterações nas quantidades de HMW plasmática têm sido mais relevantes para a predição da resistência à insulina do que alterações na concentração de adiponectina total. Assim, PAJVANI e SCHERER (2003) propuseram que um aumento plasmático de insulina poderia induzir ou ativar uma redutase plasmática que resultaria na dissociação da adiponectina HMW levando ao surgimento transitório de adiponectina de baixo peso molecular. No nosso estudo 
não avaliamos a concentração plasmática de insulina nos animais e nem a concentração da adiponectina na forma HMW (mais ativa), ficando apenas como hipótese de que o aumento de adiponectina total, e não a forma mais ativa (HMW) que apresenta características anti-inflamatórias e antiobesidade correlaciona-se com o aumento encontrado nos animais obesos.

Em relação ao tratamento com chá verde foi observada uma redução da resistência à insulina nos animais que receberam a dieta de cafeteria, perda de peso, diminuição dos depósitos de tecido adiposo e do IA, independente da condição de obesidade. De acordo com TSUNEKI et al. (2004) o tratamento com chá verde em camundongos obesos $(\mathrm{db} / \mathrm{db})$ foi capaz de diminuir os níveis circulantes de glicose através da inibição da captação de glicose intestinal pelo transportador de glicose dependente de sódio (SGLT1).

Neste estudo o chá verde não foi capaz de diminuir a concentração de leptina plasmática, porém foi eficaz na redução de ácidos graxos livres e no aumento da adiponectina, correlacionando-se positivamente com a perda de peso e maior sensibilidade à insulina observada nesses animais. Esses efeitos do chá verde podem ser sustentados por diversos dados da literatura que demonstram ações antiobesidade do chá verde e ações termogênicas desse fitoterápico (BOSE et al., 2008; SAE-TAN; GROVE; LAMBERT, 2011; WOLFRAM et al., 2005).

Um número grande de mecanismos tem sido propostos para explicar os efeitos antiobesidade do chá verde. Um desses mecanismos sugeridos por diversos autores é a modulação da absorção de lipídeos da dieta pelo chá verde. MURAMATSU; FUKUYO e HARA (1986) e YANG; WANG e CHEN (2001) observaram em seus trabalhos que o extrato do chá verde e as catequinas isoladas a partir do chá verde aumentam o conteúdo fecal de lipídeos em ratos obesos. Além disso, substâncias como os flavonóides do chá verde possuem capacidade de atuar sobre o sistema nervoso através da modulação da noradrenalina, aumentando a termogênese e a oxidação das gorduras, evitando, dessa forma, o aumento no tamanho e quantidade de adipócitos, consequentemente, prevenindo o depósito de gordura no organismo e regulando o peso corporal (LIN; LIN-SHIAU, 2006). De acordo com CHEN et al. (2005) as catequinas são capazes de inibir a enzima catecol-o-metiltransferase (COMT, enzima que degrada catecolaminas), promovendo assim um tempo maior de atuação da noradrenalina nos tecidos. Além disso, estudos mostram que as catequinas desempenham um papel importante no 
controle do tecido adiposo, principalmente pela regulação que a EGCG exerce sobre algumas enzimas relacionadas ao anabolismo e catabolismo lipídico, como a acetil CoA carboxilase, AG sintetase, lipase pancreática, lipase gástrica e lipooxigenase (LIN; LIN-SHIAU, 2006).

Sabe-se que alterações na função das células imunes no indivíduo obeso são consideradas significantes no desenvolvimento dos efeitos fisiopatológicos da obesidade. Entretanto, os mecanismos diretos e indiretos responsáveis pelas diferenças na resposta imunológica e na defesa do organismo entre indivíduos saudáveis e obesos ainda não estão totalmente esclarecidos (MILNER; BECK, 2012). Assim, em resposta à obesidade nossa hipótese inicial era de que os linfócitos de animais obesos já apresentassem uma pré-ativação com consequente aumento da proliferação celular. Além disso, já está descrito que a hiperleptinemia pode causar um aumento na proliferação de células $\mathrm{T}$ e modular a expressão de marcadores de ativação em células T CD4 e CD8 (LORD et al., 1998; PAPATHANASSOGLOU et al., 2006; ZARKESH-ESFAHANI et al., 2001). Contudo, a leptina também pode causar um impacto negativo na função e distribuição de células $T$ reguladoras, o que acarretaria, por sua vez, em um processo inflamatório com liberação de citocinas inflamatórias e espécies reativas de oxigênio por células imunes efetoras. Já é descrito na literatura que na obesidade ocorre uma prevalência de linfócitos Th1 em relação à Th2 no tecido adiposo e diminuição das defesas antioxidantes das células, contribuindo assim para o quadro de estresse oxidativo e inflamação de baixo grau característicos da obesidade (MARTIN-ROMERO et al., 2000). Assim, como estratégia terapêutica, esperávamos que o tratamento com o chá verde fosse capaz de controlar a ativação e proliferação dos linfócitos, com consequente diminuição da liberação de fatores pró-inflamatórios além do controle do estado redox, uma vez que as catequinas possuem características antioxidantes e anti-inflamatórias. Essas ações previstas para o tratamento com o extrato do chá verde proveria um ambiente mais adequado, com menor liberação de mediadores inflamatórios e diminuição do estresse oxidativo, contribuindo assim para uma redução do desenvolvimento de doenças secundárias à obesidade.

Neste estudo observamos que os animais obesos apresentaram um aumento na proliferação celular (condição basal) em relação ao grupo controle. Esse aumento na proliferação demonstra que os linfócitos presentes nos animais obesos 
encontram-se em um estado de pré-ativação, devido provavelmente ao contato direto com substâncias que poderiam levar à ativação celular, como por exemplo, ácidos graxos livres, leptina, DAMPs entre outros, confirmando assim nossa hipótese inicial de que o estado de obesidade acarreta em uma estimulação/ativação do sistema imunológico.

A avaliação da capacidade proliferativa dos linfócitos na presença dos estímulos LPS e ConA teve como objetivo avaliar a qualidade da resposta dessas células contra antígenos. Entretanto, na presença desses dois mitógenos, o grupo obeso (DH sem CV) não apresentou alteração significativa na proliferação celular. Fato intrigante e que nos faz pensar se a concentração de mitógeno utilizada no nosso estudo atingiu um "teto", impedindo-nos de observar quaisquer alterações na proliferação celular estimulada pelo mitógeno. Em contrapartida, o tratamento com chá verde foi capaz de reduzir a capacidade proliferativa dessas células tanto na condição basal como também sob o estímulo de ConA na presença de obesidade, enquanto que sob o estímulo de LPS, observamos uma redução da proliferação na ausência de obesidade. Sendo assim, esses resultados demonstram que o tratamento com o chá verde é capaz de modular a proliferação dos linfócitos independentemente da dieta, porém esse efeito antiproliferativo difere de acordo com o estímulo utilizado para induzir a mitose. Essa ação antiproliferativa já foi descrita por diversos autores, como por exemplo, $\mathrm{Hu}$ e colaboradores que mostraram que a EGCG inibiu tanto a proliferação de células B quanto $T$, com um efeito maior sendo observado sobre as células T (HU et al., 1992). Outras pesquisas reportaram que a suplementação in vitro com extrato de chá verde inibiu a proliferação de linfócitos em resposta ao estímulo de Con $A$ e estimuladores alogênicos celulares (KIM et al., 2007; WILASRUSMEE et al., 2002). De acordo com PAE et al. (2010) a suplementação com EGCG por 6 semanas foi efetiva na redução da proliferação ex vivo de células $T$ quando estimuladas com ConA ou antiCD3/CD28.

$\mathrm{Na}$ literatura não existem trabalhos demonstrando uma modulação direta dos receptores de lecitinas pelas catequinas do chá verde. Entretanto diversos autores relatam que o chá verde é capaz de diminuir a interação e reconhecimento do LPS pela molécula CD14, além de comprometer a ativação e sinalização dos receptores Toll like 4 (HONG BYUN et al., 2010). Esse efeito do chá verde está diretamente relacionado com a interação da EGCG com o receptor de membrana 67 laminina. 
No estudo, $1 \mu \mathrm{M}$ de EGCG diminuiu a expressão na superfície celular e a concentração proteica de TLR4, além de regular positivamente a expressão da proteína inibitória Tollip (HONG BYUN et al., 2010). A ativação de TLR4 medeia a sinalização de NFKB e MAPK com a produção de mediadores inflamatórios, enquanto que a proteína Tollip é capaz de regular negativamente a sinalização de TLR4 por suprimir a atividade quinase de IRAK que participa dessa via de sinalização (LI et al., 2013). Esses resultados sugerem que as catequinas, entre elas a EGCG suprimem a via de sinalização que envolve o TLR4 através do receptor de laminina diminuindo assim a produção de mediadores inflamatórios. Permanece por ser avaliado se este modelo de inibição está acontecendo nos linfócitos deste estudo.

Como regulador importante da proliferação, diferenciação e metabolismo dos linfócitos, a IL-2, uma citocina secretada pelos linfócitos $T$ sob estimulação de antígenos, lecitinas e anticorpos anti-CD3, quando se liga a receptores de superfície nas células (IL-2R) leva à ativação dos linfócitos T (TKACZUK et al., 2002), promovendo o início da proliferação da célula e regulando a transição da fase G1 para a fase $S$ do ciclo celular (WANG et al., 2004). De acordo com o trabalho de WU et al. (2009) o tratamento com EGCG em diversas concentrações (0,5 a $10 \mu \mathrm{M})$ em linfócitos de camundongos, foi capaz de interromper a sinalização de IL-2/IL-2R por diminuir a expressão de IL-2R e consequentemente suprimir a capacidade proliferativa dessas células. Esses achados foram parcialmente validados no nosso estudo já que a produção de IL-2 mostrou-se aumentada no grupo controle que recebeu chá (DP com CV) e mostrou-se diminuída no grupo obeso tratado com chá (DH com CV) (Tabela 3). Em ambas os grupos houve uma diminuição na proliferação dos linfócitos, sugerindo assim mais um possível mecanismo do chá verde na modulação da capacidade proliferativa dessas células, que é independente da condição de obesidade.

Em relação à produção de citocinas, observamos que o grupo obeso diminuiu a produção de IL-10 em relação ao grupo controle (DP sem CV), não mostrando alteração na produção de outras citocinas. Estes dados sugerem que o aumento de leptina e adiponectina observado nos animais obesos poderia estar modulando a ativação, proliferação e produção de citocinas pelos linfócitos. Entretanto, essas adipocinas são capazes de produzir efeitos opostos sobre essas células. A leptina parece promover um aumento na proliferação e diferenciação de linfócitos Th1, 
aumentando a produção de citocinas inflamatórias, sendo também capaz de suprimir a expressão de Foxp3 e a expansão de linfócitos Treg. A adiponectina, por sua vez atua diminuindo a proliferação de linfócitos Th1 com consequente diminuição da produção de citocinas pró-inflamatórias, sendo, portanto capaz de promover um aumento na proliferação de células Treg que secretam IL-10 (anti-inflamatória). O ensaio de ELISA que analisou a produção das citocinas pelos linfócitos dos animais obesos, mostrou uma diminuição significativa na produção de IL-10, devido talvez à ação da leptina, enquanto que as citocinas pró-inflamatórias não foram alteradas, levantando a hipótese de que o aumento de adiponectina estaria suprimindo a resposta inflamatória.

O tratamento com o chá verde em nosso trabalho foi responsável por diminuir a produção de diversas citocinas pró-inflamatórias nos animais suplementados, independentemente da dieta. A inibição da sinalização do receptor TLR4 pelas catequinas do chá verde poderia justificar a redução observada na produção de citocinas efetoras, como IL-6, TNF- $\alpha$ e IL-1ß, independente da condição de obesidade. Ressaltando que a produção dessas citocinas foi induzida pelo estímulo de LPS, um agonista do receptor TLR4. Além disso, observamos que o chá verde (DH com CV) foi capaz de restaurar a produção de IL-10 que estava diminuída nos animais obesos (DH sem CV) (Tabela 3).

A modulação da produção de citocinas desencadeada pelo chá verde já foi descrita por diversos autores na literatura, e uma das hipóteses baseia-se na capacidade da EGCG em modular a diferenciação de células T CD4 em células T efetoras. De acordo com WANG et al. (2013), a EGCG foi capaz de inibir a diferenciação de células T CD4 nos subtipos efetores Th1, Th17 e Th9. Contudo a EGCG não afetou diretamente a diferenciação de células Treg. Foi observado também que a EGCG antagonizou o efeito supressivo da IL-6 na diferenciação de Treg. A IL-6 é um importante fator de diferenciação para células Th17. Elevações de IL-6 redirecionam a diferenciação de Treg induzida por TGF- $\beta$ em Th17, aumentando a razão de Th17/Treg (BETTELLI et al., 2006; KORN et al., 2008). Entretanto, no nosso estudo não avaliamos a produção de citocinas na condição basal (sem estímulo), isto foi realizado apenas no grupo controle, como um parâmetro da funcionalidade do ensaio. A avaliação dessas citocinas na condição basal seria importante para traçarmos um perfil de diferenciação e ativação dos linfócitos nos grupos avaliados. Por outro lado, o uso de estímulos serviu como uma 
ferramenta para avaliarmos a qualidade da resposta dessas células contra antígenos, mimetizando uma condição de infecção/inflamação.

Diversas funções desempenhadas pelos linfócitos podem ser controladas pelo influxo de cálcio intracelular. O cálcio atua como um segundo mensageiro necessário para controlar processos como proliferação, diferenciação, apoptose e uma variedade de programas de transcrição gênica como NFAT, AP-1 e NFKB (PALKOWITSCH et al., 2011). De acordo com nossos resultados foi observado que o grupo DH com CV (obeso + chá) apresentou um aumento (não significativo) na concentração de cálcio em relação aos demais. Porém a diminuição da proliferação e da produção de citocinas observada neste grupo nos faz descartar o possível papel do cálcio atuando nestes processos e supor que esse segundo mensageiro pode estar atuando sobre outra via de sinalização.

Em relação ao estado redox dos linfócitos, o aumento observado da atividade da enzima SOD em linfócitos de animais obesos (DH sem CV) sugere que a indução de SOD Mn foi necessária para suportar o aumento da produção mitocondrial de ânion superóxido que foi evidenciada no ensaio de DHE. A produção de ânion superóxido também pode ser proveniente da ativação do complexo enzimático NADPH oxidase, justificando assim o aumento da atividade da SOD CuZn, que está presente no citoplasma celular. Notavelmente foi observado um aumento na marcação da sonda DCFH-DA, já que essa sonda é sensível a diversas espécies reativas de oxigênio. Realizamos no laboratório alguns ensaios com o intuito de verificar a especificidade da sonda DCFH-DA e observamos que na presença de 50 $\mu \mathrm{M}$ de $\mathrm{H}_{2} \mathrm{O}_{2}$ há uma evidente marcação, enquanto que o estímulo de PMA não apresentou o mesmo efeito. Além disso, a adição da enzima SOD aumentou a marcação da DCFH-DA, confirmando sua alta reatividade com $\mathrm{O}_{2} \mathrm{H}_{2}$. O peróxido de hidrogênio é o principal produto da dismutação de ânion superóxido catalisada por qualquer isoforma da SOD. Entretanto, no nosso estudo a atividade da catalase não foi alterada. Apesar disso, a enzima GPx citosólica pode remover baixas concentrações de $\mathrm{H}_{2} \mathrm{O}_{2}$. Agindo em conjunto, a enzima antioxidante GR recicla glutationa oxidada (produzida a partir da reação da GPx com $\circ \mathrm{H}_{2} \mathrm{O}_{2}$ ) à sua forma reduzida (GSH), a fim de manter a capacidade antioxidante do meio intracelular na presença de agentes oxidantes. Observamos na Tabela 4 que o grupo obeso (DH sem CV) apresentou um aumento na atividade da GPx (não significativo) e na atividade da GR, sendo isto um indicador de que houve uma maior produção de 
peróxidos ou hidroperóxidos na condição de obesidade. Não foi observado alteração em relação à razão GSH/GSSG, demonstrando assim não haver dano celular neste grupo.

Neste estudo o extrato de chá verde na condição de obesidade (DH com CV), apresentou uma diminuição significativa na produção de ânion superóxido (ensaio de DHE) e na produção de EROs total (ensaio de DCFH-DA) em relação ao grupo obeso (DH sem $\mathrm{CV}$ ). Em relação às enzimas antioxidantes, observamos um aumento (porém não significativo) da SOD Mn, diminuição da SOD CuZn e aumento significativo na atividade das enzimas GPx e GR. Na ausência de obesidade (DP com $\mathrm{CV}$ ), foi observada uma redução (não significativa) na produção de ânion superóxido ao mesmo tempo em que, não houve alteração na produção de EROs total avaliado no ensaio de DCFH-DA. Além disso, neste mesmo grupo observamos um aumento significativo na atividade da SOD Mn, SOD CuZn e GR em relação ao grupo controle (DP sem CV). Foi observado também um aumento significativo da razão GSH/GSSG pelo chá verde na condição de obesidade em relação ao grupo obeso (DH sem $\mathrm{CV}$ ), demonstrando uma maior proteção celular contra danos oxidativos.

$\mathrm{Na}$ literatura já está bem descrito que o chá verde é um potente antioxidante com atividade antioxidante superior as das vitaminas C e E (WISEMAN; BALENTINE; FREI, 1997). Além de possuir efeito scavenger para espécies reativas de oxigênio e nitrogênio, o chá verde também aumenta a expressão de enzimas antioxidantes endógenas como a glutationa redutase, glutationa peroxidade, glutationa-s-transferase e catalase (KHAN et al., 1992; VALERIO et al., 2001). As enzimas antioxidantes previnem a peroxidação lipídica e os danos à estrutura do DNA numa condição de aumento de EROs.

O mecanismo pelo qual o chá verde e as catequinas do chá verde são capazes de induzir a atividade das enzimas antioxidantes ainda está sendo estudado. Entretanto, diversos trabalhos apontam (CHEN et al., 2000; KWEON et al., 2006; LEE-HILZ et al., 2006; SHEN et al., 2005) a capacidade das catequinas em induzir uma regulação positiva de enzimas detoxificantes ou antioxidantes via sinalização Nrf2. O Nrf2 é um fator de transcrição que regula a expressão de muitas enzimas detoxificantes e antioxidantes. A proteína 1 associada Kelch-like-ECH (Keap1) atua como supressora citoplasmática de Nrf2, inibindo a translocação desse fator para o núcleo (KOBAYASHI et al., 2006; ZHANG; HANNINK, 2003). Acredita-se 
que formas reativas ou formas oxidadas da EGCG (EGCG*) podem se conjugar com a glutationa reduzida (GSH) ocasionando assim uma diminuição na concentração de GSH celular, alterando desse modo o estado redox da célula com subsequente ativação de algumas quinases, como a fosfatidilinositol 3-quinase (PI3K), proteína quinase C (PKC) e MAPKs, como JNK e ERK, levando a fosforilação de Nrf2. Alternativamente, algumas formas reativas de EGCG $\left(E G C G^{\star}\right)$ podem diretamente interagir com resíduos de cisteína presentes na proteína Keap1, estimulando a dissociação de Nrf2. No núcleo, Nrf2 associa-se a elementos de resposta antioxidante (ARE) ou a elementos de resposta eletrofílica (EpRE) para estimular a expressão de enzimas detoxificantes de fase II ou as enzimas antioxidantes (NA; SURH, 2008).

Em relação à atividade metabólica, a atividade da enzima hexoquinase nos permitiu avaliar a capacidade dos linfócitos em utilizar glicose, já que esta enzima é a primeira da via glicolítica, e atua fosforilando a molécula de glicose a glicose-6fosfato. Na avaliação dessa enzima nos animais obesos ( $\mathrm{DH}$ sem $\mathrm{CV}$ ), observamos um aumento significativo comparado ao grupo controle. Essa atividade favorece a geração de ATP, pois a glicose pode ser metabolizada pela via glicolítica ou sofrer oxidação completa via fosforilação oxidativa, corroborando com o aumento de EROs observado nos linfócitos e o aumento na glicemia (ITT e GTT) observado nesses animais. Por outro lado, o chá verde na condição de obesidade (DH com CV) foi capaz de diminuir a atividade dessa enzima em relação ao grupo obeso. Além disso, a atividade da G6PDH também foi diminuída pelo tratamento com o chá verde, em ambas as condições. Assim, podemos inferir que uma menor oferta de nutrientes às células provocaria uma diminuição na proliferação celular conforme foi observado em nosso estudo, evento que demanda alta quantidade de energia celular. A diminuição da atividade metabólica também acarreta em uma menor produção de EROs pelas células, como foi de fato observado nos animais tratados com chá verde.

De uma forma geral, as células se comunicam entre si e respondem a condições do microambiente através de vias de transdução de sinal. A via de sinalização PI3K/Akt/mTOR integra os sinais intra- e extracelulares para controlar o metabolismo, crescimento, proliferação e sobrevivência celular. A ativação de mTOR estimula vias metabólicas específicas, incluindo a glicólise, síntese de lipídeos e atividade mitocondrial. Além disso, mTOR possui um papel importante na 
diferenciação de células T (WAICKMAN; POWELL, 2012). A ativação celular dependente do reconhecimento de antígenos apresentados por APCs, integra a via de sinalização TCR/PI3K/Akt/mTOR. Consequentemente, mTOR desencadeia uma mudança metabólica na célula, com aumento da atividade glicolítica e síntese proteica necessárias para a ativação das células $T$, proliferação e diferenciação dos linfócitos em subtipos efetores, Th1, Th2 e Th17 (WAICKMAN; POWELL, 2012). De acordo com VAN ALLER et al. (2011) a EGCG pode ser considerada um inibidor potente da PI3K e mTOR. De acordo com o trabalho, a EGCG é um inibidor competitivo de ATP da PI3K e mTOR, e a potência da EGCG na inibição da PI3K e mTOR ocorre em relevantes concentrações fisiológicas $(0,8 \mu \mathrm{M}-1,6 \mu \mathrm{M})$. Consequentemente a inibição de PI3K e mTOR nos linfócitos pode ocasionar diminuição da atividade glicolítica, síntese proteica e diferenciação em subtipos Th1, Th2 e Th17 com aumento na população de células Treg. Se esse modelo de inibição está acontecendo em nosso trabalho fica por ser avaliado. Diante dos dados apresentados, a Figura 15 resume um modelo proposto de atuação do chá verde sobre os linfócitos dos animais.

Figura 15 - Modelo de atuação do chá verde sobre os linfócitos

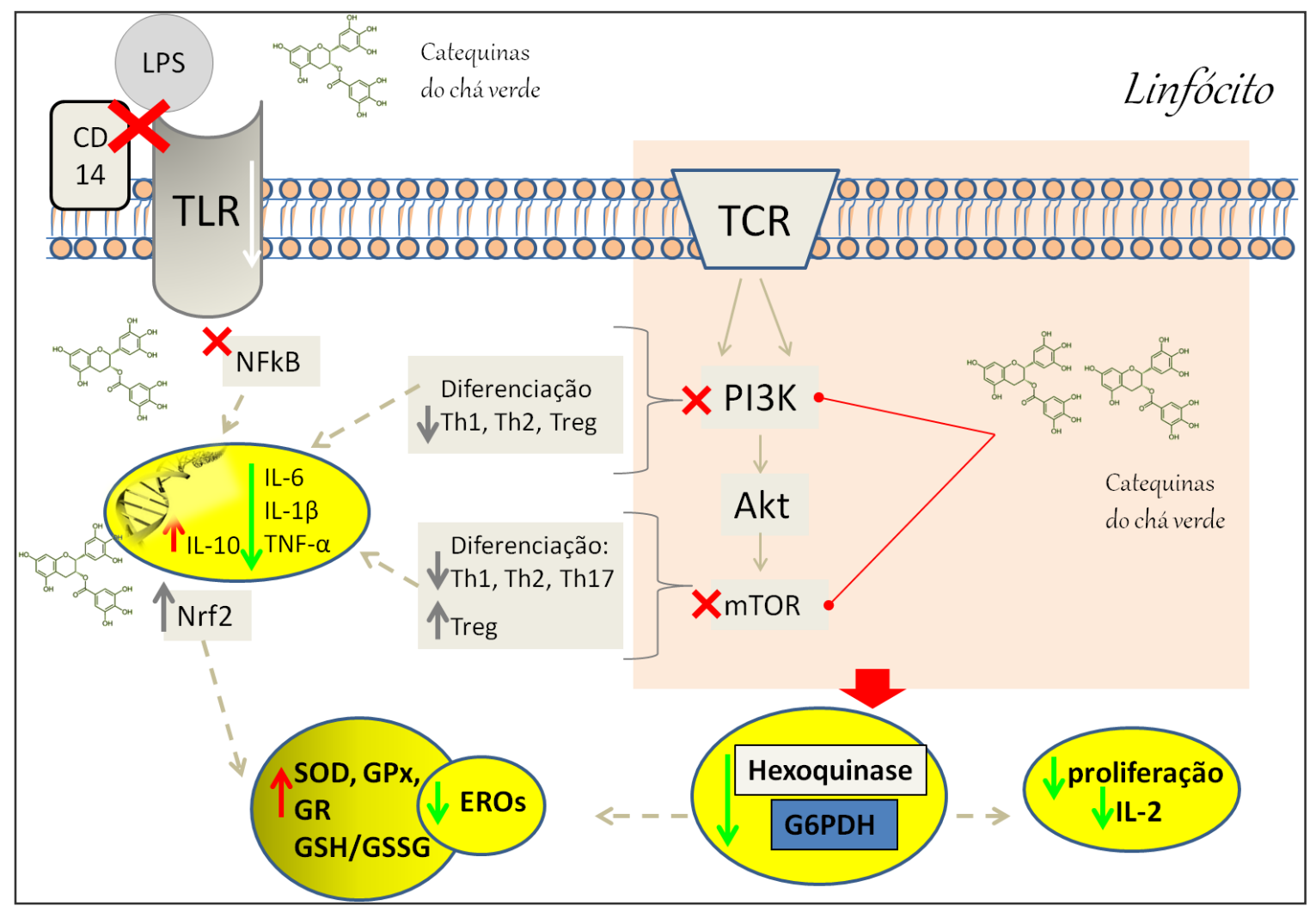


A ativação celular decorrente do reconhecimento de antígenos através de APCs/TCR, desencadeia a sinalização PI3K/Akt/mTOR, com consequente rearranjo metabólico, síntese proteica e proliferação celular. A inibição de PI3K e mTOR pelo tratamento com o chá verde, desencadeia em uma diminuição da atividade glicolítica, como foi observado em nossos resultados com a redução da atividade da hexoquinase e glicose-6-fosfato desidrogenase, além da redução da capacidade proliferativa. Essa via também é capaz de promover uma diferenciação nos subtipos de linfócitos, a inibição de PI3K levaria a uma redução na diferenciação nos subtipos Th1, Th2 e Treg, enquanto que a inibição de mTOR desencadeia a redução nos subtipos Th1, Th2, Th17 e em um aumento na população de células $T$ reg. Essa diferenciação celular pode estar contribuindo com a diminuição da produção de citocina efetoras (IL-6, IL-1 $\beta$ e TNF- $\alpha$ ) e aumento da IL-10 (anti-inflamatória) observada em nossos resultados pelo tratamento com o chá verde, independente da dieta. Por outro lado, a diminuição de citocinas efetoras pode ser devido ao comprometimento da sinalização TR4, desencadeada pela interação das catequinas com o receptor de membrana 67 laminina. Essa interação é capaz de interromper de forma indireta na sinalização do TLR4, diminuindo sua expressão proteica, sua interação com o LPS (via CD14) e a liberação e migração do fator NFKB ao núcleo. O efeito antioxidante observado em nosso modelo, com redução de ERO, enzimas antioxidantes e razão GSH/GSSG pode ser devido à ativação do fator de transcrição $\mathrm{Nrf}_{2}$. Formas ativas das catequinas (oxidadas) podem ativar o fator Nrf2 e promover sua translocação ao núcleo, desencadeando assim no aumento da expressão gênica de diversas enzimas antioxidantes.

Alguns estudos em humanos, animais e em culturas celulares demonstram que macro e micronutrientes como carboidratos, lipídeos, proteínas, vitaminas e minerais são capazes de regular a expressão gênica em diversos pontos das vias intracelulares. Além dos tradicionais integrantes da dieta, diversas substâncias químicas bioativas, de origem natural nos alimentos, como os fitoquímicos (carotenos, tocoferóis, flavonoides etc.) demonstram habilidades cada vez mais inusitadas com interface celular (VERGÈRES, 2013). Recentes estudos demonstram que drogas, alimentos e até mesmo atividade física são capazes de modular fatores como, por exemplo, a metilação do DNA e interferir diretamente na expressão de diversas proteínas e, consequentemente, no ambiente intracelular (LING, 2012). De acordo com alguns trabalhos a expressão do fator Foxp3 pode ser epigeneticamente modulada (LAL et al., 2009). Já foram identificadas diversas regiões não codificadoras dentro do lócus Foxp3 que não são metiladas em células Treg, permitindo a expressão de Foxp3. Normalmente, essas regiões são bastante metiladas em células T CD4 naive, causando assim a repressão da expressão de Foxp3. A desmetilação da região promotora de Foxp3 em células T CD 4 naive com o uso de alguns inibidores resultou na expressão de Foxp3 e subsequentemente na diferenciação de células T CD4 em células Treg (LAL; BROMBERG, 2009). Assim, de acordo com WONG et al. (2011), camundongos tratados com EGCG tiveram um aumento significativo na quantidade de células Treg no baço e linfonodos. Este mesmo trabalho justifica que a indução da expressão de Foxp3 está correlacionada 
com a redução da expressão de enzimas DNA metiltransferases (DMNT) e redução total da metilação causada pela EGCG, sendo este um mecanismo epigenético pelo qual a EGCG atuaria nas células.

De forma geral, podemos afirmar que nosso modelo de indução de obesidade por dieta hipercalórica foi bem sucedido. Ficou evidente que a mudança alimentar, com a incorporação de alimentos hipercalóricos é capaz de ocasionar alterações metabólicas que podem ser estendidas aos linfócitos dos animais acometidos pela obesidade, como foi observado em nossos resultados, com o aumento na produção de EROs e diminuição de IL-10, fato este que poderia contribuir para o quadro de estresse oxidativo, hiperativação de células do sistema imune e consequentemente ativação de processos inflamatórios encontrado nos indivíduos obesos.

De fato, a melhor solução para melhorar a saúde de indivíduos obesos é a perda significativa de peso corporal. Entretanto, a etiologia desta doença é altamente complexa e multifatorial e, portanto, nenhuma solução para a obesidade ocorrerá facilmente. A obesidade interfere claramente com a proteção do organismo contra agentes infecciosos e um aumento no número de pesquisas nessa área se faz necessário a fim de compreendermos a relação do excesso de tecido adiposo observado na síndrome metabólica com o sistema imunológico.

A utilização de abordagens nutricionais para modular a função imunológica é uma estratégia potencialmente promissora que pode afetar a regulação imunológica e a evolução das doenças auto-imunes. Assim, a estratégia terapêutica proposta neste estudo, com a suplementação com extrato de chá verde nos animais obesos apresentou-se bastante eficiente na redução da produção de EROs, melhora do estado redox e diminuição na produção de citocinas pró-inflamatórias pelos linfócitos. Esses mesmos resultados foram observados com o tratamento do extrato de chá verde na ausência de obesidade, fortalecendo a ideia de que esses efeitos são de fato provenientes do chá verde, quer na condição de obesidade ou eutrofia. Além disso, a utilização de fitoterápicos pode promover a diferenciação epigenética de células Treg e do fator Foxp3, representando um novo mecanismo com potencial para modular as respostas imunológicas, já que estas se encontram alteradas em indivíduos obesos em função das alterações na população de células imunes, com evidente supressão de células Treg. Embora os agentes dietéticos como as catequinas encontradas no extrato do chá verde, podem não ser tão potentes como agentes farmacológicos, a sua capacidade para atingir mecanismos semelhantes 
oferece oportunidades para exposições sustentadas em longo prazo, sem associação com toxicidade.

Estudos científicos recentes consideram a $C$. sinensis uma planta estratégica para a saúde humana no século $\mathrm{XXI}$. As pesquisas com o chá verde revelam de forma crescente seu efeito restaurador de estados patológicos e, por tratar-se de uma bebida amplamente disponível e de baixo custo, torna-se viável o seu uso como um importante coadjuvante nutricional em diversas doenças. No entanto, não se pode ansiar que um único fitoterápico tenha a capacidade de proporcionar um impacto de grandes proporções sobre a saúde. Entretanto, é importante observar que mesmo um efeito modesto pode ter um impacto importante sobre as causas mais prevalentes de morbidade e mortalidade das DCNT, merecendo assim maior atenção, tendo em vista que em pouco tempo o consumo regular de chá verde poderá ser considerado como parte das dietas ocidentais. 


\section{Conclusões}

Com base nos resultados obtidos e apresentados nesta dissertação, podemos concluir que:

1. O nosso modelo de dieta de cafeteria (hipercalórica) induziu estresse oxidativo em linfócitos representados pelo expressivo aumento na produção de espécies reativas de oxigênio, independente da presença do estímulo PMA (conforme demonstraram as sondas DCFH-DA e DHE). Além disso, houve aumento da capacidade proliferativa (basal) e redução da produção de $\mathrm{IL}-10$.

2. O chá verde foi capaz de reduzir a proliferação celular e a produção de citocinas pró-inflamatórias (IL-1 $1 \beta$, TNF- $\alpha$ e IL-6), independente da condição de obesidade e o tratamento com o chá verde na condição de obesidade foi capaz de aumentar a produção de IL-10 comparado ao grupo obeso.

3. O chá verde foi capaz de reduzir a produção de espécies reativas de oxigênio na condição de obesidade, independente do estímulo de PMA (sondas DCFH-DA e DHE). Este fato provavelmente ocorreu devido ao aumento da atividade das enzimas antioxidantes SOD, GPx e GR.

4. A razão GSH/GSSG foi aumentada pelo chá verde na condição de obesidade, corroborando assim para a melhora do estado redox celular.

5. Em relação ao metabolismo celular, o chá verde foi capaz de reduzir a atividade das enzimas hexoquinase e glicose-6-fosfato-desidrogenase. 


\section{REFERÊNCIAS*}

AHERNE, S. A.; O'BRIEN, N. M. Dietary flavonols: chemistry, food content, and metabolism. Nutrition, v. 18, n. 1, p.75-81, 2002.

AHIMA, R. S. et al. Leptin regulation of neuroendocrine systems. Frontiers in Neuroendocrinology, v. 21, n. 3, p.263-307, 2000.

AHMAD, S.; VARGA, T. V.; FRANKS, P. W. Gene x Environment Interactions in Obesity: The State of the Evidence. Human Heredity, v. 75 , n. 2-4, p.106-115, 2013.

AKIRA, S.; TAKEDA, K. Functions of toll-like receptors: lessons from KO mice. Comptes Rendus Biologies, v. 327, n. 6, p.581-589, 2004.

AKIRA, S.; UEMATSU, S.; TAKEUCHI, O. Pathogen recognition and innate immunity. Cell, v. 124, n. 4, p.783-801, 2006.

AMADOU, A.; HAINAUT, P.; ROMIEU, I. Role of obesity in the risk of breast cancer: lessons from anthropometry. Journal of Oncology, v. 2013, n., p.906495, 2013.

ARDAWI, M. S.; NEWSHOLME, E. A. Maximum activities of some enzymes of glycolysis, the tricarboxylic acid cycle and ketone-body and glutamine utilization pathways in lymphocytes of the rat. Biochemical Journal, v. 208, n. 3, p.743-748, 1982.

BABU, P. V.; LIU, D. Green tea catechins and cardiovascular health: an update. Current Medicinal Chemistry, v. 15, n. 18, p.1840-1850, 2008.

BARTOLOMUCCI, A. et al. Metabolic consequences and vulnerability to diet-induced obesity in male mice under chronic social stress. PloS one, v. 4, n. 1, p.e4331, 2009.

BENDICH, A. Physiological role of antioxidants in the immune system. Journal of Dairy Science, v. 76, n. 9, p.2789-2794, 1993.

1

\footnotetext{
$1 *$ De acordo com: ASSOCIAÇÃO BRASILEIRA DE NORMAS TÉCNICAS. NBR 6023: informação e documentação: referências: elaboração. Rio de Janeiro, 2002.
} 
BENTAL, M.; DEUTSCH, C. Metabolic changes in activated T cells: an NMR study of human peripheral blood lymphocytes. Magnetic resonance in medicine : official journal of the Society of Magnetic Resonance in Medicine / Society of Magnetic Resonance in Medicine, v. 29, n. 3, p.317-326, 1993.

BETTELLI, E. et al. Reciprocal developmental pathways for the generation of pathogenic effector TH17 and regulatory T cells. Nature, v. 441, n. 7090, p.235-238, 2006.

BEUTLER, E. G6PD deficiency. Blood, v. 84, n. 11, p.3613-3636, 1994.

BLASIUS, A. L.; BEUTLER, B. Intracellular toll-like receptors. Immunity, v. 32, n. 3, p.305-315, 2010.

BODE, A. M.; DONG, Z. Epigallocatechin 3-gallate and green tea catechins: United they work, divided they fail. Cancer Prevention Research, v. 2, n. 6, p.514-517, 2009.

BOGDANSKI, P. et al. Green tea extract reduces blood pressure, inflammatory biomarkers, and oxidative stress and improves parameters associated with insulin resistance in obese, hypertensive patients. Nutrition Research, v. 32, n. 6, p.421427, 2012.

BÖIERS, C. et al. Lymphomyeloid Contribution of an Immune-Restricted Progenitor Emerging Prior to Definitive Hematopoietic Stem Cells. Cell Stem Cell, v., n. 0, 2013.

BOLIN, A. P. et al. Changes in lymphocyte oxidant/antioxidant parameters after carbonyl and antioxidant exposure. International Immunopharmacology, v. 14, n. 4, p.690-697, 2012.

BOSE, M. et al. The major green tea polyphenol, (-)-epigallocatechin-3-gallate, inhibits obesity, metabolic syndrome, and fatty liver disease in high-fat-fed mice. Journal of Nutrition, v. 138, n. 9, p.1677-1683, 2008.

BRADFORD, M. M. A rapid and sensitive method for the quantitation of microgram quantities of protein utilizing the principle of protein-dye binding. Analytical Biochemistry, v. 72, n., p.248-254, 1976.

BURNEIKO, R. C. et al. Interaction of hypercaloric diet and physical exercise on lipid profile, oxidative stress and antioxidant defenses. Food and Chemical Toxicology : an international journal published for the British Industrial Biological Research Association, v. 44, n. 7, p.1167-1172, 2006. 
BUTTKE, T. M.; SANDSTROM, P. A. Oxidative stress as a mediator of apoptosis. Immunology Today, v. 15, n. 1, p.7-10, 1994.

CABALLERO, B. The global epidemic of obesity: an overview. Epidemiologic Reviews, v. 29, n., p.1-5, 2007.

CABRERA, C.; ARTACHO, R.; GIMENEZ, R. Beneficial effects of green tea- a review. Journal of the American College of Nutrition, v. 25, n. 2, p.79-99, 2006.

CALDER, P. C. Dietary fatty acids and lymphocyte functions. The Proceedings of the Nutrition Society, v. 57, n. 4, p.487-502, 1998.

CARBONE, F.; LA ROCCA, C.; MATARESE, G. Immunological functions of leptin and adiponectin. Biochimie, v. 94, n. 10, p.2082-2088, 2012.

CARO-MALDONADO, A.; GERRIETS, V. A.; RATHMELL, J. C. Matched and mismatched metabolic fuels in lymphocyte function. Seminars in Immunology, v. 24, n. 6, p.405-413, 2012.

CASAZZA, K. et al. Myths, presumptions, and facts about obesity. The New England Journal of Medicine, v. 368, n. 5, p.446-454, 2013.

CAWTHORN, W. P.; SETHI, J. K. TNF-alpha and adipocyte biology. FEBS Letters, v. 582, n. 1, p.117-131, 2008.

CESARETTI, M. L.; KOHLMANN JUNIOR, O. Experimental models of insulin resistance and obesity: lessons learned. Arquivos Brasileiros de Endocrinologia e Metabologia, v. 50, n. 2, p.190-197, 2006.

CHACKO, S. M. et al. Beneficial effects of green tea: a literature review. Chinese Medicine, v. 5, n., p.13, 2010.

CHAMP, P. C. HARVEY, R.A. Lippincoths illustrated reviews: biochemistry. 2 ed. Philadelphia:Wolthers Kluver Health, 1994. 420 p.

CHANDRA, R. K.; KUTTY, K. M. Immunocompetence in obesity. Acta Paediatrica Scandinavica, v. 69, n. 1, p.25-30, 1980.

CHAWLA, A.; NGUYEN, K. D.; GOH, Y. P. Macrophage-mediated inflammation in metabolic disease. Nature Reviews. Immunology, v. 11, n. 11, p.738-749, 2011. 
CHEN, C. et al. Activation of antioxidant-response element (ARE), mitogen-activated protein kinases (MAPKs) and caspases by major green tea polyphenol components during cell survival and death. Archives of Pharmacal Research, v. 23, n. 6, p.605612, 2000.

CHEN, D. et al. Inhibition of human liver catechol-O-methyltransferase by tea catechins and their metabolites: structure-activity relationship and molecularmodeling studies. Biochemical Pharmacology, v. 69, n. 10, p.1523-1531, 2005.

CHEN, L. et al. Absorption, distribution, elimination of tea polyphenols in rats. Drug Metabolism and Disposition: the biological fate of chemicals, v. 25, n. 9, p.1045-1050, 1997.

CHENGELIS, C. P. et al. 28-Day oral (gavage) toxicity studies of green tea catechins prepared for beverages in rats. Food and chemical toxicology : an international journal published for the British Industrial Biological Research Association, v. 46, n. 3, p.978-989, 2008.

CHOY, E. H.; PANAYI, G. S. Cytokine pathways and joint inflammation in rheumatoid arthritis. New England Journal of Medicine, v. 344, n. 12, p.907-916, 2001.

CIRCU, M. L.; AW, T. Y. Reactive oxygen species, cellular redox systems, and apoptosis. Free Radical Biology \& Medicine, v. 48, n. 6, p.749-762, 2010.

COMMITTEE ON DIET AND HEALTH, N. R. C. Diet and health: implications for reducing chronic disease risk. n. 750, 1989 p. 564.

CRABTREE, B.; NEWSHOLME, E. A. The activities of phosphorylase, hexokinase, phosphofructokinase, lactate dehydrogenase and the glycerol 3-phosphate dehydrogenases in muscles from vertebrates and invertebrates. Biochemical Journal, v. 126, n. 1, p.49-58, 1972.

CRESPY, V.; WILLIAMSON, G. A review of the health effects of green tea catechins in in vivo animal models. Journal of Nutrition, v. 134, n. 12 Suppl, p.3431s-3440s, 2004.

DANIELE, N. et al. T(reg) cells: collection, processing, storage and clinical use. Pathology Research and Practice, v. 207, n. 4, p.209-215, 2011.

DARNTON-HILL, I.; NISHIDA, C.; JAMES, W. P. A life course approach to diet, nutrition and the prevention of chronic diseases. Public Health Nutrition, v. 7, n. 1a, p.101-121, 2004. 
DE CATERINA, R.; ZAMPOLLI, A. From asthma to atherosclerosis--5-lipoxygenase, leukotrienes, and inflammation. New England Journal of Medicine, v. 350, n. 1, p.4-7, 2004.

DE MEJIA, E. G.; RAMIREZ-MARES, M. V.; PUANGPRAPHANT, S. Bioactive components of tea: cancer, inflammation and behavior. Brain, Behavior, and Immunity, v. 23, n. 6, p.721-731, 2009.

DE PASCUAL-TERESA, S.; MORENO, D. A.; GARCIA-VIGUERA, C. Flavanols and anthocyanins in cardiovascular health: a review of current evidence. International Journal of Molecular Sciences, v. 11, n. 4, p.1679-1703, 2010.

DE ROSA, V. et al. A key role of leptin in the control of regulatory $T$ cell proliferation. Immunity, v. 26, n. 2, p.241-255, 2007.

DELGOFFE, G. M. et al. The mTOR kinase differentially regulates effector and regulatory T cell lineage commitment. Immunity, v. 30, n. 6, p.832-844, 2009.

DEYULIA, G. J., Jr. et al. Hydrogen peroxide generated extracellularly by receptorligand interaction facilitates cell signaling. Proceedings of the National Academy of Sciences of the United States of America, v. 102, n. 14, p.5044-5049, 2005.

DI CAPITE, J.; PAREKH, A. B. CRAC channels and Ca2+ signaling in mast cells. Immunological Reviews, v. 231, n. 1, p.45-58, 2009.

DORN, A. D. et al. Characterization of mitogen-stimulated porcine lymphocytes using a stable fluorescent dye (PKH2) and multicolor flow cytometry. Veterinary Immunology and Immunopathology, v. 87, n. 1-2, p.1-10, 2002.

DROGE, W. Free radicals in the physiological control of cell function. Physiological Reviews, v. 82, n. 1, p.47-95, 2002.

EL-HAG, A. et al. Immunomodulation by neutrophil myeloperoxidase and hydrogen peroxide: differential susceptibility of human lymphocyte functions. Journal of Immunology, v. 136, n. 9, p.3420-3426, 1986.

EWING, J. F.; JANERO, D. R. Microplate superoxide dismutase assay employing a nonenzymatic superoxide generator. Analytical Biochemistry, v. 232, n. 2, p.243248, 1995. 
FANTUZZI, G.; MAZZONE, T. Adipose tissue and atherosclerosis: exploring the connection. Arteriosclerosis, Thrombosis, and Vascular Biology, v. 27, n. 5, p.996-1003, 2007.

FORMAN, H. J.; TORRES, M. Signaling by the respiratory burst in macrophages. IUBMB Life, v. 51, n. 6, p.365-371, 2001.

FOX, C. J.; HAMMERMAN, P. S.; THOMPSON, C. B. Fuel feeds function: energy metabolism and the T-cell response. Nature Reviews. Immunology, v. 5, n. 11, p.844-852, 2005.

FUJISAKA, S. et al. Regulatory mechanisms for adipose tissue M1 and M2 macrophages in diet-induced obese mice. Diabetes, v. 58, n. 11, p.2574-2582, 2009.

FUKUHARA, A. et al. Visfatin: a protein secreted by visceral fat that mimics the effects of insulin. Science, v. 307, n. 5708, p.426-430, 2005.

GAIDE, O. et al. CARMA1 is a critical lipid raft-associated regulator of TCR-induced NF-kappa B activation. Nature Immunology, v. 3, n. 9, p.836-843, 2002.

GELDERMAN, K. A. et al. T cell surface redox levels determine T cell reactivity and arthritis susceptibility. Proceeding of the National Academy of Sciences of United States of America, v. 103, n. 34, p.12831-12836, 2006.

GINN-PEASE, M. E.; WHISLER, R. L. Redox signals and NF-kappaB activation in T cells. Free Radical Biology \& Medicine, v. 25, n. 3, p.346-361, 1998.

GOTTFREDSEN, R. H. et al. Hydrogen peroxide induce modifications of human extracellular superoxide dismutase that results in enzyme inhibition. Redox Biology, v. 1, n. 1, p.24-31, 2013.

GRAHAM, H. N. Green tea composition, consumption, and polyphenol chemistry. Preventive Medicine, v. 21, n. 3, p.334-350, 1992.

GRANT, R. et al. Quantification of adipose tissue leukocytosis in obesity. Methods in Molecular Biology, v. 1040, n., p.195-209, 2013.

GREGOR, M. F.; HOTAMISLIGIL, G. S. Inflammatory mechanisms in obesity. Annual Review of Immunology, v. 29, n., p.415-445, 2011. 
HADA, Y. et al. Selective purification and characterization of adiponectin multimer species from human plasma. Biochemical and Biophysical Research Communications, v. 356, n. 2, p.487-493, 2007.

HALLIWELL, B.; GUTTERIDGE, J. Free radicals in Biology and Medicine. 4 ed. Oxford: Oxford University Press, 2006. 936 p.

HALLIWELL, B.; GUTTERIDGE, J. M. The antioxidants of human extracellular fluids. Archives of Biochemistry and Biophysics, v. 280, n. 1, p.1-8, 1990.

HANSSON, L. Asthma-like conditions still not completely mapped. Capsaicin may give a differential diagnosis--but is not yet ready for clinical use. Lakartidningen, $v$. 102, n. 50, p.3867-3868, 2005.

HASLAM, D. W.; JAMES, W. P. Obesity. Lancet, v. 366, n. 9492, p.1197-1209, 2005.

HASLER, C. M. Functional foods: benefits, concerns and challenges-a position paper from the american council on science and health. Journal of Nutrition, v. 132, n. 12, p.3772-3781, 2002.

HOGAN, P. G. et al. Transcriptional regulation by calcium, calcineurin, and NFAT. Genes \& Development, v. 17, n. 18, p.2205-2232, 2003.

HOGAN, P. G.; RAO, A. Dissecting ICRAC, a store-operated calcium current. Trends in Biochemical Science, v. 32, n. 5, p.235-245, 2007.

HOLMBERG, L. Obesity, nutrition, and prostate cancer: insights and issues. European Urology, v. 63, n. 5, p.821-822, 2013.

HONG BYUN, E. et al. TLR4 signaling inhibitory pathway induced by green tea polyphenol epigallocatechin-3-gallate through $67-\mathrm{kDa}$ laminin receptor. Journal of Immunology, v. 185, n. 1, p.33-45, 2010.

HOWARD, J. K.; FLIER, J. S. Attenuation of leptin and insulin signaling by SOCS proteins. Trends in Endocrinology and Metabolism: TEM, v. 17, n. 9, p.365-371, 2006.

HU, F. B.; MALIK, V. S. Sugar-sweetened beverages and risk of obesity and type 2 diabetes: epidemiologic evidence. Physiology \& Behavior, v. 100, n. 1, p.47-54, 2010. 
HU, Z. Q. et al. Mitogenic activity of (-)epigallocatechin gallate on B-cells and investigation of its structure-function relationship. International Journal of Immunopharmacology, v. 14, n. 8, p.1399-1407, 1992.

JACKSON, S. H. et al. T cells express a phagocyte-type NADPH oxidase that is activated after $\mathrm{T}$ cell receptor stimulation. Nature Immunology, v. 5, n. 8, p.818827, 2004.

JOSEFOWICZ, S. Z.; LU, L. F.; RUDENSKY, A. Y. Regulatory T cells: mechanisms of differentiation and function. Annual Review of Immunology, v. 30, n., p.531-564, 2012.

KAMATA, H.; HIRATA, H. Redox regulation of cellular signalling. Cell Signal, v. 11, n. 1, p.1-14, 1999.

KAMEI, N. et al. Overexpression of monocyte chemoattractant protein-1 in adipose tissues causes macrophage recruitment and insulin resistance. Journal of Biological Chemistry, v. 281, n. 36, p.26602-26614, 2006.

KAWAI, T.; AKIRA, S. The role of pattern-recognition receptors in innate immunity: update on Toll-like receptors. Nature Immunology, v. 11, n. 5, p.373-384, 2010.

KHAN, S. G. et al. Enhancement of antioxidant and phase II enzymes by oral feeding of green tea polyphenols in drinking water to $\mathrm{SKH}-1$ hairless mice: possible role in cancer chemoprevention. Cancer Research, v. 52, n. 14, p.4050-4052, 1992.

KIM, J. Y. et al. Tea polyphenol inhibits allostimulation in mixed lymphocyte culture. Cell Transplantation, v. 16, n. 1, p.75-83, 2007.

KNIGHT, J. A. Review: Free radicals, antioxidants, and the immune system. Annals of Clinical and Laboratory Science, v. 30, n. 2, p.145-158, 2000.

KOBAYASHI, A. et al. Oxidative and electrophilic stresses activate Nrf2 through inhibition of ubiquitination activity of Keap1. Molecular and Cellular Biology, v. 26, n. 1, p.221-229, 2006.

KOBAYASHI, $\mathrm{H}$. et al. Selective suppression of endothelial cell apoptosis by the high molecular weight form of adiponectin. Circulation Research, v. 94, n. 4, p.e27-31, 2004. 
KOHARYOVA, M.; KOLAROVA, M. Oxidative stress and thioredoxin system. General Physiology Biophysics, v. 27, n. 2, p.71-84, 2008.

KONDO, M. et al. Biology of hematopoietic stem cells and progenitors: implications for clinical application. Annual Review of Immunology, v. 21, n., p.759-806, 2003.

KOO, M. W.; CHO, C. H. Pharmacological effects of green tea on the gastrointestinal system. European Journal of Pharmacology, v. 500, n. 1-3, p.177-185, 2004.

KOPELMAN, P. Health risks associated with overweight and obesity. Obesity reviews : an official journal of the International Association for the Study of Obesity, v. 8 Suppl 1, n., p.13-17, 2007.

KORN, T. et al. IL-6 controls Th17 immunity in vivo by inhibiting the conversion of conventional $T$ cells into Foxp3+ regulatory $T$ cells. Proceedings of the National Academy of Sciences of the United States of America, v. 105, n. 47, p.1846018465, 2008.

KWEON, M. $\mathrm{H}$. et al. Constitutive overexpression of Nrf2-dependent heme oxygenase-1 in A549 cells contributes to resistance to apoptosis induced by epigallocatechin 3-gallate. Journal of Biological Chemistry, v. 281, n. 44, p.3376133772, 2006.

LAL, G.; BROMBERG, J. S. Epigenetic mechanisms of regulation of Foxp3 expression. Blood, v. 114, n. 18, p.3727-3735, 2009.

LAL, G. et al. Epigenetic regulation of Foxp3 expression in regulatory T cells by DNA methylation. Journal of Immunology, v. 182, n. 1, p.259-273, 2009.

LAMBERT, J. D. et al. Epigallocatechin-3-gallate is absorbed but extensively glucuronidated following oral administration to mice. Journal of Nutrition, v. 133, n. 12, p.4172-4177, 2003.

LARBI, A.; KEMPF, J.; PAWELEC, G. Oxidative stress modulation and T cell activation. Experimental Gerontology, v. 42, n. 9, p.852-858, 2007.

LAU, D. C.; TEOH, H. Benefits of modest weight loss on the management of type 2 diabetes mellitus. Canadian Journal of Diabetes, v. 37, n. 2, p.128-134, 2013.

LEE-HILZ, Y. Y. et al. Pro-oxidant activity of flavonoids induces EpRE-mediated gene expression. Chemical Research in Toxicology, v. 19, n. 11, p.1499-1505, 2006. 
LEE, B. C.; LEE, J. Cellular and molecular players in adipose tissue inflammation in the development of obesity-induced insulin resistance. Biochimica et Biophysica Acta, v., n., 2013.

LEE, H.; BAE, S.; YOON, Y. The anti-adipogenic effects of (-)epigallocatechin gallate are dependent on the WNT/beta-catenin pathway. Journal of Nutritional Biochemistry, v. 24, n. 7, p.1232-1240, 2013.

LEWIS, R. S. The molecular choreography of a store-operated calcium channel. Nature, v. 446, n. 7133, p.284-287, 2007.

$\mathrm{LI}$, J. et al. Toll-like receptors as therapeutic targets for autoimmune connective tissue diseases. Pharmacology \& Therapeutics, v. 138, n. 3, p.441-451, 2013.

LIMON-PACHECO, J.; GONSEBATT, M. E. The role of antioxidants and antioxidantrelated enzymes in protective responses to environmentally induced oxidative stress. Mutation Research, v. 674, n. 1-2, p.137-147, 2009.

LIN, J.; DELLA-FERA, M. A.; BAILE, C. A. Green tea polyphenol epigallocatechin gallate inhibits adipogenesis and induces apoptosis in 3T3-L1 adipocytes. Obesity Research, v. 13, n. 6, p.982-990, 2005.

LIN, J. K.; LIN-SHIAU, S. Y. Mechanisms of hypolipidemic and anti-obesity effects of tea and tea polyphenols. Molecular Nutrition \& Food Research, v. 50, n. 2, p.211$217,2006$.

LING, C. Epigenetics in the Pathophysiology of Type 2 Diabetes. In: BAGCHI, D.; SREEJAYAN, N. Nutritional and therapeutic interventions for diabetes and metabolic syndrome. San Diego: Academic Press, 2012. p.225-232.

LOPES, H. F.; EGAN, B. M. Autonomic dysregulation and the metabolic syndrome: pathologic partners in an emerging global pandemic. Arquivos Brasileiros de Cardiologia, v. 87, n. 4, p.538-547, 2006.

LORD, G. M. et al. Leptin modulates the T-cell immune response and reverses starvation-induced immunosuppression. Nature, v. 394, n. 6696, p.897-901, 1998.

LOTITO, S. B. et al. Metabolic conversion of dietary flavonoids alters their antiinflammatory and antioxidant properties. Free Radical Biology \& Medicine, v. 51, n. 2, p.454-463, 2011. 
LUMENG, C. N. et al. Increased inflammatory properties of adipose tissue macrophages recruited during diet-induced obesity. Diabetes, v. 56, n. 1, p.16-23, 2007.

MACEDO, I. C. et al. Cafeteria diet-induced obesity plus chronic stress alter serum leptin levels. Peptides, v. 38, n. 1, p.189-196, 2012.

MACIAN, F. NFAT proteins: key regulators of T-cell development and function. Nature Reviews. Immunology, v. 5, n. 6, p.472-484, 2005.

MALY, F. E. et al. Superoxide-dependent nitroblue tetrazolium reduction and expression of cytochrome b-245 components by human tonsillar B lymphocytes and B cell lines. Journal of Immunology, v. 142, n. 4, p.1260-1267, 1989.

MARKLUND, S. L. Extracellular superoxide dismutase in human tissues and human cell lines. Journal of Clinical Investigation, v. 74, n. 4, p.1398-1403, 1984.

MARTI, A.; MARCOS, A.; MARTINEZ, J. A. Obesity and immune function relationships. Obesity Reviews : an official journal of the International Association for the Study of Obesity, v. 2, n. 2, p.131-140, 2001.

MARTIN-ROMERO, C. et al. Human leptin enhances activation and proliferation of human circulating T lymphocytes. Cellular Immunology, v. 199, n. 1, p.15-24, 2000.

MARTIN, S. S.; QASIM, A.; REILLY, M. P. Leptin resistance: a possible interface of inflammation and metabolism in obesity-related cardiovascular disease. Journal of the American College of Cardiology, v. 52, n. 15, p.1201-1210, 2008.

MATHIS, D.; SHOELSON, S. E. Immunometabolism: an emerging frontier. Nature Reviews. Immunology, v. 11, n. 2, p.81, 2011.

MATSUE, $H$. et al. Generation and function of reactive oxygen species in dendritic cells during antigen presentation. Journal of Immunology, v. 171, n. 6, p.30103018, 2003.

MATSUZAWA, Y.; FUNAHASHI, T.; NAKAMURA, T. The concept of metabolic syndrome: contribution of visceral fat accumulation and its molecular mechanism. Journal of Atherosclerosis and Thrombosis, v. 18, n. 8, p.629-639, 2011.

MAURI, C. Regulation of immunity and autoimmunity by B cells. Current Opinion in Immunology, v. 22, n. 6, p.761-767, 2010. 
MAURI, C.; EHRENSTEIN, M. R. The 'short' history of regulatory B cells. Trends in Immunology, v. 29, n. 1, p.34-40, 2008.

MEDZHITOV, R. Toll-like receptors and innate immunity. Nature Reviews of Immunology, v. 1, n. 2, p.135-145, 2001.

MEDZHITOV, R.; JANEWAY, C., Jr. Innate immune recognition: mechanisms and pathways. Immunology Reviews, v. 173, n., p.89-97, 2000.

MILLER, R. A.; BRITIGAN, B. E. The formation and biologic significance of phagocyte-derived oxidants. Journal of Investigative Medicine : the official publication of the American Federation for Clinical Research, v. 43, n. 1, p.3949, 1995.

MILNER, J. J.; BECK, M. A. The impact of obesity on the immune response to infection. Proceedings of the Nutrition Society, v. 71, n. 02, p.298-306, 2012.

MODERNO, P. M.; CARVALHO, M.; SILVA, B. M. Recent patents on Camellia sinensis: source of health promoting compounds. Recent Patents on Food, Nutrition \& Agriculture, v. 1, n. 3, p.182-192, 2009.

MOREAU, E.; CHAUVIN, A. Immunity against helminths: interactions with the host and the intercurrent infections. Journal of Biomedicine \& Biotechnology, v. 2010, n., p.428593, 2010.

MOSSER, D. M.; EDWARDS, J. P. Exploring the full spectrum of macrophage activation. Nature Reviews. Immunology, v. 8, n. 12, p.958-969, 2008.

MUNOZ, M.; MAZURE, R. A.; CULEBRAS, J. M. Obesity and the immune system. Nutricion Hospitalaria, v. 19, n. 6, p.319-324, 2004.

MURAMATSU, K.; FUKUYO, M.; HARA, Y. Effect of green tea catechins on plasma cholesterol level in cholesterol-fed rats. Journal of Nutritional Science and Vitaminology, v. 32, n. 6, p.613-622, 1986.

MYKKANEN, L.; LAAKSO, M.; PYORALA, K. Association of obesity and distribution of obesity with glucose tolerance and cardiovascular risk factors in the elderly. International Journal of Obesity and Related Metabolic Disorders : journal of the International Association for the Study of Obesity, v. 16, n. 9, p.695-704, 1992. 
NA, H. K.; SURH, Y. J. Modulation of Nrf2-mediated antioxidant and detoxifying enzyme induction by the green tea polyphenol EGCG. Food and Chemical Toxicology : an international journal published for the British Industrial Biological Research Association, v. 46, n. 4, p.1271-1278, 2008.

NGUYEN, D. M.; EL-SERAG, H. B. The epidemiology of obesity. Gastroenterology Clinics of North America, v. 39, n. 1, p.1-7, 2010.

ODEGAARD, J. I. et al. Macrophage-specific PPARgamma controls alternative activation and improves insulin resistance. Nature, v. 447, n. 7148, p.1116-1120, 2007.

OESTREICH, K. J.; WEINMANN, A. S. Master regulators or lineage-specifying? Changing views on CD4+ T cell transcription factors. Nature Reviews. Immunology, v. 12, n. 11, p.799-804, 2012.

OTERO, M. et al. Leptin, from fat to inflammation: old questions and new insights. FEBS Letters, v. 579, n. 2, p.295-301, 2005.

OTTON, R. et al. Non-esterified fatty acids and human lymphocyte death: a mechanism that involves calcium release and oxidative stress. Journal of Endocrinology, v. 195, n. 1, p.133-143, 2007.

OUCHI, N. et al. Adipokines in inflammation and metabolic disease. Nature Reviews. Immunology, v. 11, n. 2, p.85-97, 2011.

OZCAN, U. et al. Endoplasmic reticulum stress links obesity, insulin action, and type 2 diabetes. Science, v. 306, n. 5695, p.457-461, 2004.

PAE, M. et al. Epigallocatechin-3-gallate directly suppresses $\mathrm{T}$ cell proliferation through impaired IL-2 utilization and cell cycle progression. Journal of Nutrition, v. 140, n. 8, p.1509-1515, 2010.

PAJVANI, U. B.; SCHERER, P. E. Adiponectin: systemic contributor to insulin sensitivity. Current Diabetes Reports, v. 3, n. 3, p.207-213, 2003.

PALKOWITSCH, L. et al. The Ca2+-dependent phosphatase calcineurin controls the formation of the Carma1-Bcl10-Malt1 complex during $\mathrm{T}$ cell receptor-induced NFkappaB activation. Journal of Biological Chemistry, v. 286, n. 9, p.7522-7534, 2011. 
PAPATHANASSOGLOU, E. et al. Leptin receptor expression and signaling in lymphocytes: kinetics during lymphocyte activation, role in lymphocyte survival, and response to high fat diet in mice. Journal of Immunology, v. 176, n. 12, p.77457752, 2006.

PAULI, J. R. et al. Novos mecanismos pelos quais o exercício físico melhora a resistência à insulina no músculo esquelético. Arquivos Brasileiros de Endocrinologia \& Metabologia, v. 53, n., p.399-408, 2009.

PEARCE, E. L.; PEARCE, E. J. Metabolic pathways in immune cell activation and quiescence. Immunity, v. 38, n. 4, p.633-643, 2013.

PETER, C.; WALDMANN, H.; COBBOLD, S. P. mTOR signalling and metabolic regulation of $T$ cell differentiation. Current Opinion in Immunology, v. 22, n. 5, p.655-661, 2010.

PI-SUNYER, F. X. Health implications of obesity. American Journal of Clinical Nutrition, v. 53, n. 6 Suppl, p.1595S-1603S, 1991.

PORES-FERNANDO, A. T.; ZWEIFACH, A. Calcium influx and signaling in cytotoxic T-lymphocyte lytic granule exocytosis. Immunological Reviews, v. 231, n. 1, p.160173, 2009.

POWERS, S. K. et al. Dietary antioxidants and exercise. Journal of Sports Sciences, v. 22, n. 1, p.81-94, 2004.

RAHMAN, I.; BISWAS, S. K.; KIRKHAM, P. A. Regulation of inflammation and redox signaling by dietary polyphenols. Biochemical Pharmacology, v. 72, n. 11, p.14391452, 2006.

RAHMAN, I.; KODE, A.; BISWAS, S. K. Assay for quantitative determination of glutathione and glutathione disulfide levels using enzymatic recycling method. Nature Protocols, v. 1, n. 6, p.3159-3165, 2006.

RETH, M. Hydrogen peroxide as second messenger in lymphocyte activation. Nature Immunology, v. 3, n. 12, p.1129-1134, 2002.

ROBERTS, C. K. et al. Oxidative stress and dysregulation of NAD(P)H oxidase and antioxidant enzymes in diet-induced metabolic syndrome. Metabolism: clinical and experimental, v. 55, n. 7, p.928-934, 2006. 
ROMAGNANI, S. Lymphokine production by human T cells in disease states. Annual Review of Immunology, v. 12, n., p.227-257, 1994.

ROSSI, F. et al. High-Density Lipoprotein Cholesterol Affects Early Endothelial Progenitor Cell Number and Endothelial Function in Obese Women. Obesity, v., n., 2013.

SAE-TAN, S.; GROVE, K. A.; LAMBERT, J. D. Weight control and prevention of metabolic syndrome by green tea. Pharmacological Research : the official journal of the Italian Pharmacological Society, v. 64, n. 2, p.146-154, 2011.

SAITO, S. T. et al. Green tea extract-patents and diversity of uses. Recent Patents on Food, Nutrition \& Agriculture, v. 1, n. 3, p.203-215, 2009.

SAMARTíN, S.; CHANDRA, R. K. Obesity, overnutrition and the immune system. Nutrition Research, v. 21, n. 1-2, p.243-262, 2001.

SANCHEZ-MARGALET, V. et al. Role of leptin as an immunomodulator of blood mononuclear cells: mechanisms of action. Clinical and Experimental Immunology, v. 133, n. 1, p.11-19, 2003.

SCHAFER, F. Q.; BUETTNER, G. R. Redox environment of the cell as viewed through the redox state of the glutathione disulfide/glutathione couple. Free Radical Biology \& Medicine, v. 30, n. 11, p.1191-1212, 2001.

SCHAFFLER, A.; SCHOLMERICH, J. Innate immunity and adipose tissue biology. Trends in Immunology, v. 31, n. 6, p.228-235, 2010.

SCHRAUFSTATTER, I. et al. Oxidant-induced DNA damage of target cells. Journal of Clinical Investigation, v. 82, n. 3, p.1040-1050, 1988.

SCHWARTZ, M. W. et al. Central nervous system control of food intake. Nature, v. 404, n. 6778, p.661-671, 2000.

SCOARIS, C. R. et al. Effects of cafeteria diet on the jejunum in sedentary and physically trained rats. Nutrition, v. 26, n. 3, p.312-320, 2010.

SEAGER, A. L. et al. Pro-oxidant induced DNA damage in human lymphoblastoid cells: homeostatic mechanisms of genotoxic tolerance. Toxicological Sciences : an official journal of the Society of Toxicology, v. 128, n. 2, p.387-397, 2012. 
SHEN, G. et al. Comparison of (-)-epigallocatechin-3-gallate elicited liver and small intestine gene expression profiles between C57BL/6J mice and C57BL/6J/Nrf2 (-/-) mice. Pharmaceutical Research, v. 22, n. 11, p.1805-1820, 2005.

SHIPKOVA, M.; WIELAND, E. Surface markers of lymphocyte activation and markers of cell proliferation. Clinica Chimica Acta; international journal of clinical chemistry, v. 413, n. 17-18, p.1338-1349, 2012.

SHOELSON, S. E.; HERRERO, L.; NAAZ, A. Obesity, inflammation, and insulin resistance. Gastroenterology, v. 132, n. 6, p.2169-2180, 2007.

SHULMAN, G. I. Cellular mechanisms of insulin resistance. Journal of Clinical Investigation, v. 106, n. 2, p.171-176, 2000.

SNYDER-CAPPIONE, J. E.; NIKOLAJCZYK, B. S. When diet and exercise are not enough, think immunomodulation. Molecular Aspects of Medicine, v. 34, n. 1, p.30-38, 2013.

STALLONE, D. D. The influence of obesity and its treatment on the immune system. Nutrition Reviews, v. 52, n. 2 Pt 1, p.37-50, 1994.

SUMNER, J. B.; HOWELL, S. F. Identification of Hemagglutinin of Jack Bean with Concanavalin A. Journal of Bacteriology, v. 32, n. 2, p.227-237, 1936.

SUN, A. Y. et al. Botanical Phenolics and Neurodegeneration. Boca Raton (FL), CRC Press Llc; 2011.

SUN, W. L. et al. Inflammatory cytokines, adiponectin, insulin resistance and metabolic control after periodontal intervention in patients with type 2 diabetes and chronic periodontitis. Internal Medicine, v. 50, n. 15, p.1569-1574, 2011.

SUN, Y.; OBERLEY, L. W. Redox regulation of transcriptional activators. Free Radical Biology \& Medicine, v. 21, n. 3, p.335-348, 1996.

SWAMY, M. et al. Epithelial decision makers: in search of the 'epimmunome'. Nature Immunology, v. 11, n. 8, p.656-665, 2010.

TACHIBANA, H. Green tea polyphenol sensing. Proceedings of the Japan Academy. Series B, Physical and biological sciences, v. 87, n. 3, p.66-80, 2011. 
TANIGUCHI, A. et al. Interleukin 6, adiponectin, leptin, and insulin resistance in nonobese Japanese type 2 diabetic patients. Metabolism: clinical and experimental, v. 55, n. 2, p.258-262, 2006.

TKACZUK, J. et al. Effect of anti-IL-2Ralpha antibody on IL-2-induced Jak/STAT signaling. American journal of transplantation : official journal of the American Society of Transplantation and the American Society of Transplant Surgeons, v. 2, n. 1, p.31-40, 2002.

TRAYHURN, P. Adipocyte biology. Obesity Reviews : an official journal of the International Association for the Study of Obesity, v. 8 Suppl 1, n., p.41-44, 2007.

TSANG, J. Y. et al. Novel immunomodulatory effects of adiponectin on dendritic cell functions. International Immunopharmacology, v. 11, n. 5, p.604-609, 2011.

TSE, H. M. et al. Disruption of innate-mediated proinflammatory cytokine and reactive oxygen species third signal leads to antigen-specific hyporesponsiveness. Journal of Immunology, v. 178, n. 2, p.908-917, 2007.

TSUNEKI, H. et al. Effect of green tea on blood glucose levels and serum proteomic patterns in diabetic $(\mathrm{db} / \mathrm{db})$ mice and on glucose metabolism in healthy humans. BMC Pharmacology, v. 4, n., p.18, 2004.

ULLMANN, U. et al. A single ascending dose study of epigallocatechin gallate in healthy volunteers. Journal of International Medical Research, v. 31, n. 2, p.88101, 2003.

VALERIO, L. G., Jr. et al. Induction of human NAD(P)H:quinone oxidoreductase (NQO1) gene expression by the flavonol quercetin. Toxicology Letters, v. 119, n. 1, p.49-57, 2001.

VALKO, M. et al. Free radicals and antioxidants in normal physiological functions and human disease. International Journal of Biochemistry \& Cell Biology, v. 39, n. 1, p.44-84, 2007.

VAN ALLER, G. S. et al. Epigallocatechin gallate (EGCG), a major component of green tea, is a dual phosphoinositide-3-kinase/mTOR inhibitor. Biochemical and Biophysical Research Communications, v. 406, n. 2, p.194-199, 2011.

VAN ITALLIE, T. B. Health implications of overweight and obesity in the United States. Annals of Internal Medicine, v. 103, n. 6 ( Pt 2), p.983-988, 1985. 
VERGÈRES, G. Nutrigenomics - Linking food to human metabolism. Trends in Food Science \& Technology, v. 31, n. 1, p.6-12, 2013.

VINCENT, H. K.; TAYLOR, A. G. Biomarkers and potential mechanisms of obesityinduced oxidant stress in humans. International Journal of Obesity, v. 30, n. 3 , p.400-418, 2006.

WAICKMAN, A. T.; POWELL, J. D. mTOR, metabolism, and the regulation of T-cell differentiation and function. Immunological Reviews, v. 249, n. 1, p.43-58, 2012.

WANG, H. et al. Ovarian carcinoma cells inhibit T cell proliferation: suppression of IL2 receptor beta and gamma expression and their JAK-STAT signaling pathway. Life Sciences, v. 74, n. 14, p.1739-1749, 2004.

WANG, J. et al. Green tea epigallocatechin-3-gallate modulates differentiation of naive CD4(+) $\mathrm{T}$ cells into specific lineage effector cells. Journal of Molecular Medicine, v. 91, n. 4, p.485-495, 2013.

WASSINK, A. M.; OLIJHOEK, J. K.; VISSEREN, F. L. The metabolic syndrome: metabolic changes with vascular consequences. European Journal of Clinical Investigation, v. 37, n. 1, p.8-17, 2007.

WEIN, S. et al. Oral green tea catechins transiently lower plasma glucose concentrations in female db/db mice. Journal of Medicinal Food, v. 16, n. 4, p.312317, 2013.

WEISBERG, S. P. et al. Obesity is associated with macrophage accumulation in adipose tissue. Journal of Clinical Investigation, v. 112, n. 12, p.1796-1808, 2003.

WHITEHEAD, J. P. et al. Adiponectin--a key adipokine in the metabolic syndrome. Diabetes, Obesity \& Metabolism, v. 8, n. 3, p.264-280, 2006.

WHO. World Health Organization. Obesity, Preventing and Management the Global Epidemic., n. 1997

WHO. World Health Organization. World Health Report. 2009. Disponível em: www.who.int/peh/burden/globalewww.who.int. Acesso em: 25 jul. 2013.

WIENANDS, J.; LARBOLETTE, O.; RETH, M. Evidence for a preformed transducer complex organized by the B cell antigen receptor. Proceeding National Academy of Science of United States of America, v. 93, n. 15, p.7865-7870, 1996. 
WILASRUSMEE, C. et al. In vitro immunomodulatory effects of ten commonly used herbs on murine lymphocytes. Journal of Alternative and Complementary of Medicine, v. 8, n. 4, p.467-475, 2002.

WILLIAMS, M. S.; KWON, J. T cell receptor stimulation, reactive oxygen species, and cell signaling. Free Radical Biology \& Medicine, v. 37, n. 8, p.1144-1151, 2004.

WINTERBOURN, C. C.; HAMPTON, M. B. Thiol chemistry and specificity in redox signaling. Free Radical Biology \& Medicine, v. 45, n. 5, p.549-561, 2008.

WISEMAN, S. A.; BALENTINE, D. A.; FREI, B. Antioxidants in tea. Critical Reviews in Food Science and Nutrition, v. 37, n. 8, p.705-718, 1997.

WOLFRAM, S. et al. TEAVIGO (epigallocatechin gallate) supplementation prevents obesity in rodents by reducing adipose tissue mass. Annals of Nutrition \& Metabolism, v. 49, n. 1, p.54-63, 2005.

WOLOWCZUK, I. et al. Feeding our immune system: impact on metabolism. Clinical \& Developmental Immunology, v. 2008, n., p.639803, 2008.

WONG, C. P. et al. Induction of regulatory T cells by green tea polyphenol EGCG. Immunology Letters, v. 139, n. 1-2, p.7-13, 2011.

WU, D. et al. Green tea EGCG suppresses T cell proliferation through impairment of IL-2/IL-2 receptor signaling. Free Radical Biology \& Medicine, v. 47, n. 5, p.636643, 2009.

$\mathrm{XU}, \mathrm{H}$. et al. Chronic inflammation in fat plays a crucial role in the development of obesity-related insulin resistance. Journal of Clinical Investigation, v. 112, n. 12, p.1821-1830, 2003.

YAMAUCHI, T.; KADOWAKI, T. Adiponectin receptor as a key player in healthy longevity and obesity-related diseases. Cell Metabolism, v. 17, n. 2, p.185-196, 2013.

YANG, H. Y. et al. Beneficial effects of catechin-rich green tea and inulin on the body composition of overweight adults. British Journal of Nutrition, v. 107, n. 5, p.749754, 2012. 
YANG, M.; WANG, C.; CHEN, H. Green, oolong and black tea extracts modulate lipid metabolism in hyperlipidemia rats fed high-sucrose diet. Journal of Nutritional Biochemistry, v. 12, n. 1, p.14-20, 2001.

ZARKESH-ESFAHANI, $\mathrm{H}$. et al. High-dose leptin activates human leukocytes via receptor expression on monocytes. Journal of Immunology, v. 167, n. 8, p.45934599, 2001.

ZENG, H.; CHI, H. mTOR and lymphocyte metabolism. Current Opinion in Immunology, v. 25, n. 3, p.347-355, 2013.

ZHANG, D. D.; HANNINK, M. Distinct cysteine residues in Keap1 are required for Keap1-dependent ubiquitination of Nrf2 and for stabilization of Nrf2 by chemopreventive agents and oxidative stress. Molecular and Cellular Biology, v. 23, n. 22, p.8137-8151, 2003. 